\title{
PFR/TREAT SAFETY EXPERIMENTS- HEDL TRANSIENT TEST PROGRAM ENGINEERING TEST PLAN
}

\section{Hanford Engineering Development Laboratory}

This document contains UK proprietary information furnished in confidence under the provisions of the PFR/TREAT Specific Memorandum of Agreement between the USDOE and the UKAEA dated November 5, 1979. This information shal 1 not be disseminated outside the USDOE and its contractors without prior approval in writing from the UKAEA. This notice shall be marked on any reproduction hereof, in whole or in part.

This document contains information furnished in confidence under the provisions of the PFR/TREAT Specific Memorandum of Agreement between the USDOE and the UKAEA dated November 5,1979 . This information shall not be disseminated outside the UKAEA, the ir contractors, 1 icensees, and concerned agencies of the UK Government without prior approval in writing from the USDOE. This notice shall be marked on any reproduction hereof, in whole or in part.

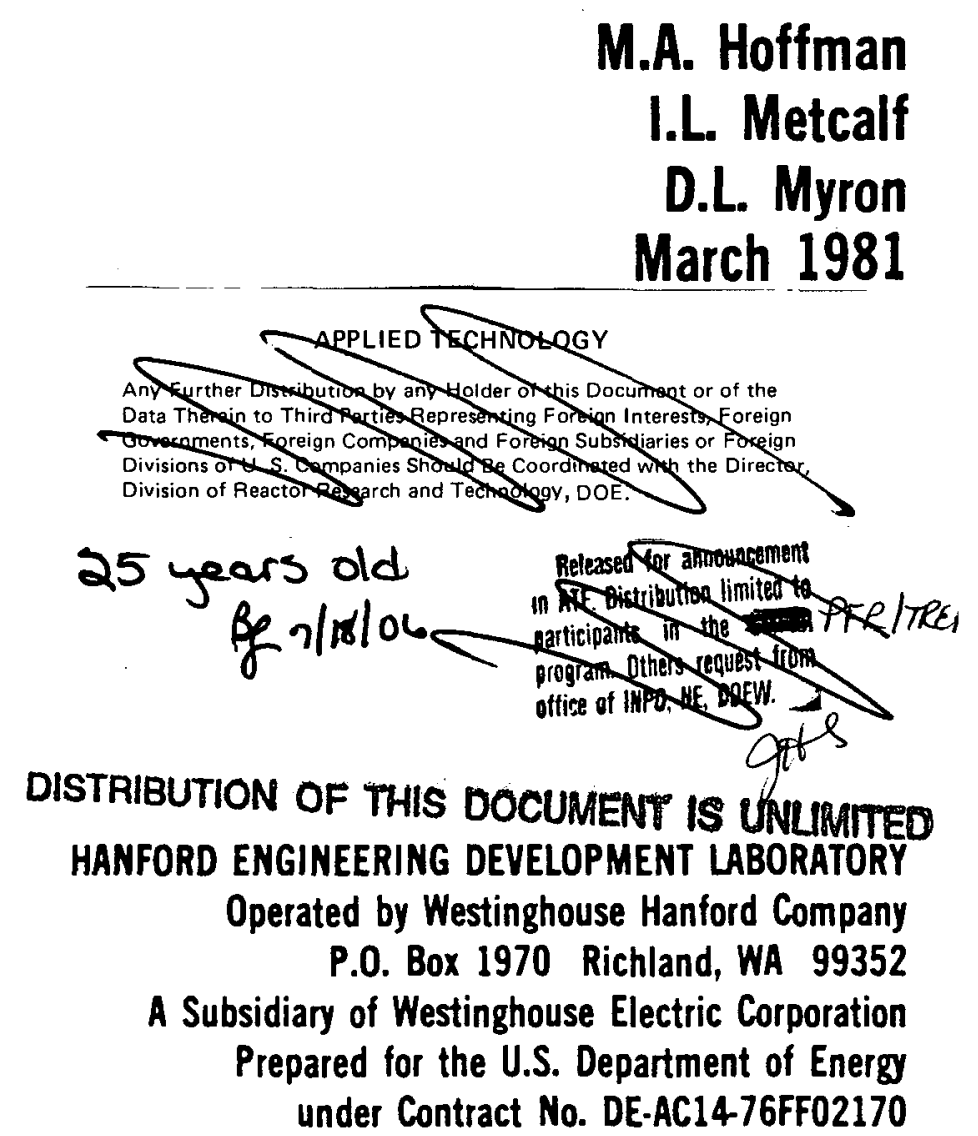




\section{DISCLAIMER}

This report was prepared as an account of work sponsored by an agency of the United States Government. Neither the United States Government nor any agency Thereof, nor any of their employees, makes any warranty, express or implied, or assumes any legal liability or responsibility for the accuracy, completeness, or usefulness of any information, apparatus, product, or process disclosed, or represents that its use would not infringe privately owned rights. Reference herein to any specific commercial product, process, or service by trade name, trademark, manufacturer, or otherwise does not necessarily constitute or imply its endorsement, recommendation, or favoring by the United States Government or any agency thereof. The views and opinions of authors expressed herein do not necessarily state or reflect those of the United States Government or any agency thereof. 


\section{DISCLAIMER}

Portions of this document may be illegible in electronic image products. Images are produced from the best available original document. 


\section{PFR TREAT SAFETY EXPERIMENTS \\ HEDL TRANSIENT TEST PROGRAM \\ ENGINEERING TEST PLAN}

I. L. Metcalf

M. A. Hoffman

D. L. Myron

March 1981

Approved:

Test Experiments and

Test Predictions:
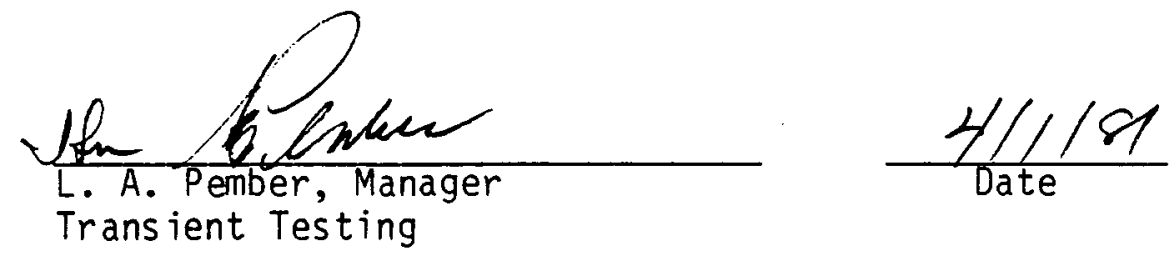

Test Train Fabrication:
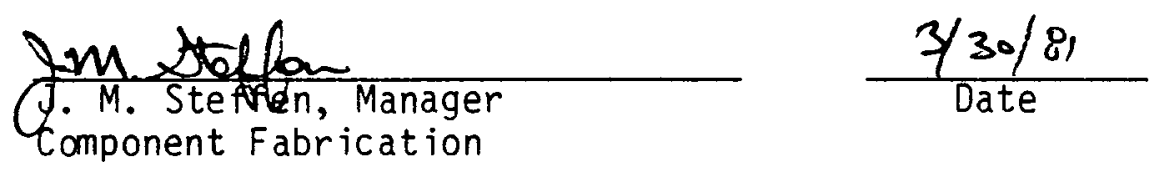

Test Article Welding:
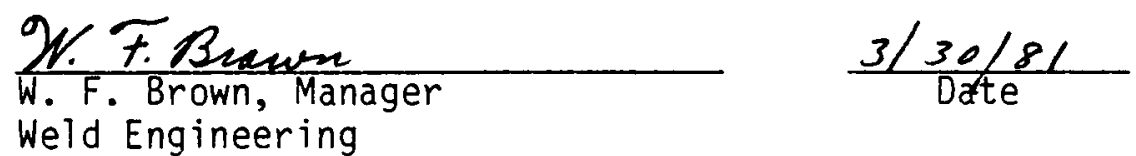

Loop Fabrication, Outfitting and Proof Testing:
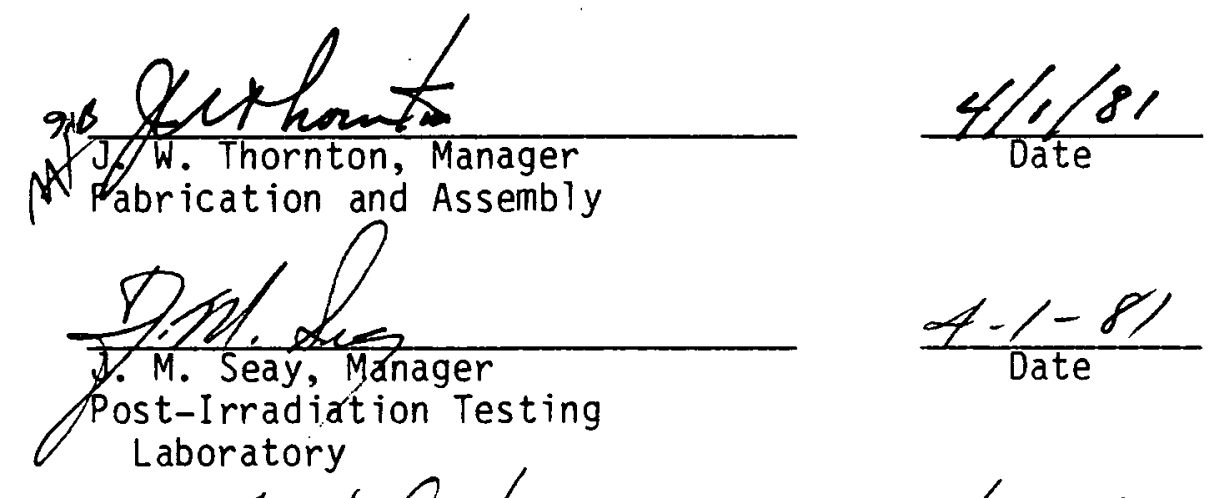

Remote Handling Operations:

Quality Assurance:
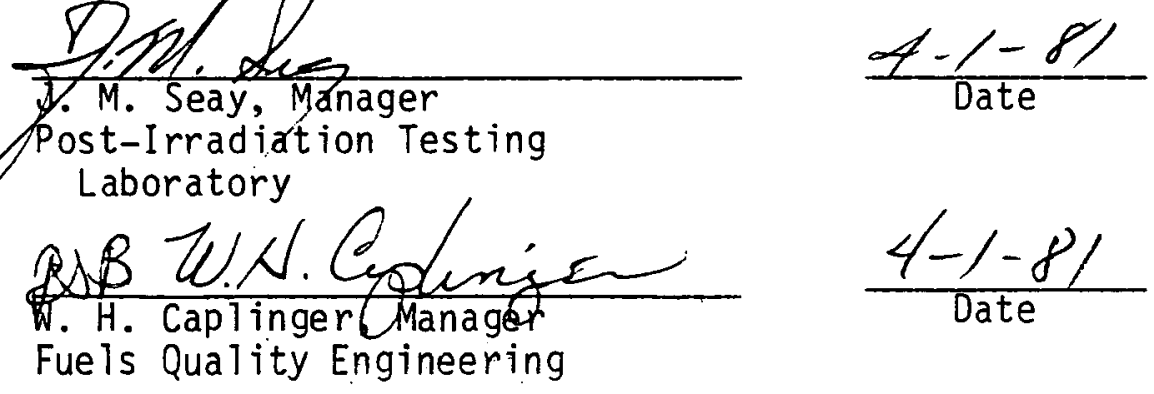


\begin{tabular}{|c|c|c|c|c|}
\hline $\begin{array}{l}\text { Hanford Engineering } \\
\text { Development Laboratory }\end{array}$ & $\begin{array}{l}\text { Westinghouse Hantord Company } \\
\text { A Subsidiary of Westinghouse Electric } \\
\text { Corporation } \\
\text { P.O. Box } 1970 \text { Richland. WA } 99352\end{array}$ & $\begin{array}{c}\text { CORE TECHNOLOGY AND SAFETY } \\
\text { ENGINEERING TEST PLAN }\end{array}$ & $\begin{array}{c}\text { REVISION } \\
1\end{array}$ & DATE \\
\hline $\begin{array}{l}\text { TEST SERIES } \\
\text { HEDL TRAN }\end{array}$ & ISIENT TEST PROGRAM & SERIES TEST PLAN & \multicolumn{2}{|l|}{ APPROVED } \\
\hline \multicolumn{2}{|c|}{ CONTENTS } & & SECTION NO. & $\begin{array}{c}\text { PAGE NO } \\
i\end{array}$ \\
\hline
\end{tabular}

\section{CONTENTS}

1.0 OBJECTIVE

2.0 AUTHOR IZATION

3.0 DEVELOPMENT PROGRAM SUMMARY

4.0 TEST COMPONENT DESCRIPTION

5.0 APPLICABLE DOCUMENTS AND DRAWINGS

6.0 MATERIALS AND HARDWARE REQUIREMENTS

7.0 FABRICATION REQUIREMENTS

8.0 WELDING REQUIREMENTS

9.0 CLEANING REQUIREMENTS

10.0 ASSEMBLY REQUIREMENTS

11.0 SHIPPING, PACKAGING, AND HANDLING REQUIREMENTS

12.0 PRE- AND POST-TRANSIENT REQUIREMENTS

13.0 REPORTS AND DOCUMENTATION

14.0 QUALITY ASSURANCE PLANS

REFERENCES

APPENDIX A - PROCEDURES FOR THE HEDL TRANSIENT TEST PROGRAM FILE SYSTEM

$A-1$

APPENDIX B - DRAWINGS-SPTL B-1

APPENDIX C - DRAWINGS-SPTT 


\begin{tabular}{|c|c|c|c|c|}
\hline $\begin{array}{l}\text { Hanford Engineering } \\
\text { Development Laboratory }\end{array}$ & 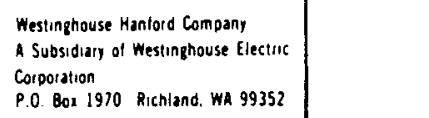 & $\begin{array}{c}\text { CORE TECHNOLOGY AND SAFETY } \\
\text { ENGINEERING TEST PLAN }\end{array}$ & $\begin{array}{c}\text { REVISION } \\
1\end{array}$ & DATE \\
\hline $\begin{array}{l}\text { TEST SERIES } \\
\text { HEDL TRAN }\end{array}$ & ISIENT TEST PROGRAM & SERIES TEST PLAN & \multicolumn{2}{|l|}{ APPROVED } \\
\hline \multicolumn{2}{|c|}{ F IGURES } & & SECTION NO. & $\begin{array}{c}\text { PAGE NO } \\
i j\end{array}$ \\
\hline
\end{tabular}

FIGURES

Figure

Page

3.1.1 US Fabricated US/UK Safety Test Program Fuel Pin

3.1.2 Typical PFR Driver Fuel Pin 3.3

3.1.3 Summary of PFR/TREAT Safety Test Program Experiments and Test Parameters $\quad 3.4$

4.1.1 Schematic Diagram of the SPTL 4.3

4.1.2 Cross Section of the SPTL at the TREAT Core $q$

4.2.1 Single Pin Test Train (SPTT) for the HEDL Transient Test Program

14.1.1 Test Program Responsibilities

14.1.2 HEDL CO6 Project Schedule

14.1.3 HEDL Transient Test Program Interface Activities 


\begin{tabular}{|c|c|c|c|c|}
\hline $\begin{array}{l}\text { Hanford Engineering } \\
\text { Development Laboratory }\end{array}$ & $\begin{array}{l}\text { Westinghouse Hantord Company } \\
\text { A Subsidiary of Westinghouse Electilic } \\
\text { Corporation } \\
\text { P.0. Box } 1970 \text { Rickiand. Wh } 99352\end{array}$ & $\begin{array}{c}\text { CORE TECHNOLOGY AND SAFETY } \\
\text { ENGINEERING TEST PLAN }\end{array}$ & $\begin{array}{r}\text { REVISION } \\
1 \\
1\end{array}$ & DATE \\
\hline $\begin{array}{l}\text { TEST SERIES } \\
\text { HEDL TRAN }\end{array}$ & SIENT TEST PROGRAM & SERIES TEST PLAN & \multicolumn{2}{|l|}{ APPROVED } \\
\hline \multicolumn{3}{|c|}{ TABLES } & SECTION NO. & PAGE NO. \\
\hline
\end{tabular}

\section{TABLES}

Table

Page

6.1.1 SPTL Pressure Boundary Components

6.2

8.1.1 Outfitting and Final Assembly Weld Qualification Requirements

8.6

8.1.2 Single Pin Test Loop ALIP and Lower Flowmeter Final Assembly Weld Qualification Requirements

8.7

8.2.1 Weld Qualification Requirements for Single Pin Test Train

14.1.1 Quality Assurance Program Index

14.2

14.1.2 Hold Points for the HEDL Transient Test Program 


\begin{tabular}{|c|c|c|c|c|}
\hline $\begin{array}{l}\text { Hanford Engineering } \\
\text { Development Laboratory }\end{array}$ & 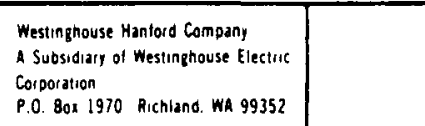 & $\begin{array}{c}\text { CORE TECHNOLOGY AND SAFETY } \\
\text { ENGINEERING TEST PLAN }\end{array}$ & $\begin{array}{c}\text { REVISION } \\
1\end{array}$ & DATE \\
\hline \multicolumn{2}{|c|}{$\begin{array}{l}\text { TEST SERIES } \\
\text { HEDL TRANSIENT TEST PROGRAM }\end{array}$} & SERIES TEST PLAN & \multicolumn{2}{|l|}{ APPROVED } \\
\hline \multicolumn{3}{|c|}{$\begin{array}{l}\text { SECTION TITLE } \\
\text { OBJECTIVE }\end{array}$} & $\begin{array}{r}\text { SECTION NO. } \\
1.0\end{array}$ & $\begin{array}{c}\text { PAGE NO. } \\
1\end{array}$ \\
\hline
\end{tabular}

1.0 OBJECTIVE

The purpose of the PFR/TREAT Safety Test Program is to obtain experimental data of fuel pin behavior during hypothetical, unprotected accidents for cores of large liquid metal cooled fast breeder reactors. The steady state and transient experiments, which will be performed under the joint program, are to be as prototypic of fast reactor performance as is possible. With respect to the transient experiments, one of the major categories of TREAT safety experiments included in the program scope is the fuel pin failure time and location experiments. When the joint program was initially formulated, the reference test vehicle for conducting the failure time and location experiments was identified as the static capsule test vehicle. Since that time, a study was conducted to determine the applicability of the static capsule test vehicle for prototypic failure time and location experiments. As a result of this study, it has been concluded that the use of the static capsule test vehicle should be limited, and flowing coolant loops should be used in their place. The first three PFR/TREAT Safety Test Program experiments, $\mathrm{CO}, \mathrm{CO} 2$ and $\mathrm{CO}$, will be conducted in the static capsule test vehicles, as covered by Engineering Test Plan TC-1439. (1) Experiments C04 and $\mathrm{CO} 5$ will be conducted in modified Mark IIIA loops, which are to be provided by ANL/RAS. Experiments $\mathrm{CO} 6$ and $\mathrm{CO} 7$ will be conducted in the most prototypic test vehicle, the Single Pin Test Loops (SPTLs). The testing approach is to initially utilize the available static capsules and transcend to the more prototypic SPTL experiments. Future HEDL testing activities, as a part of the PFR/TREAT Safety Test Program, may include multi pin initial fuel dispersal experiments in Mark III loops.

The specific objectives of this document are: (1) dictate the activities and responsibilities for the HEDL Transient Test Program, (2) specify the technical requirements for the $\mathrm{CO4}, \mathrm{CO5}, \mathrm{CO} 6$ and $\mathrm{CO} 7$ test train (SPTTs), and (3) specify the technical requirement for the $\mathrm{CO} 6$ and $\mathrm{C} 07$ Single Pin Test Loops (SPTLs). Specific requirements for single pin loop experiments beyond C07 and multi pin experiments will be covered in the addenda to this test plan. 


\begin{tabular}{|c|c|c|c|c|}
\hline $\begin{array}{l}\text { Hanford Engineering } \\
\text { Development Laboratory }\end{array}$ & $\begin{array}{l}\text { Westinghouse Manlord Company } \\
\text { A Subsidiary of Westinghouse Electiric } \\
\text { Corporation } \\
\text { P.O. Bor } 1970 \text { Richland. WA } 99352\end{array}$ & $\begin{array}{c}\text { CORE TECHNOLOGY AND SAFETY } \\
\text { ENGINEERING TEST PLAN }\end{array}$ & $\begin{array}{c}\text { REVISION } \\
1\end{array}$ & DATE \\
\hline \multicolumn{2}{|c|}{$\begin{array}{l}\text { TEST SERIES } \\
\text { HEDL TRANSIENT TEST PROGRAM }\end{array}$} & SERIES TEST PLAN & \multicolumn{2}{|l|}{ APPROVED } \\
\hline \multicolumn{3}{|c|}{ AUETION TITLE } & $\begin{array}{r}\text { SECTION NO } \\
2.0\end{array}$ & $\begin{array}{c}\text { PAGE NO. } \\
1\end{array}$ \\
\hline
\end{tabular}

\subsection{AUTHORIZATION}

Work described by this test plan is authorized under Cost Account Authorization (CAA) 5010102 . 


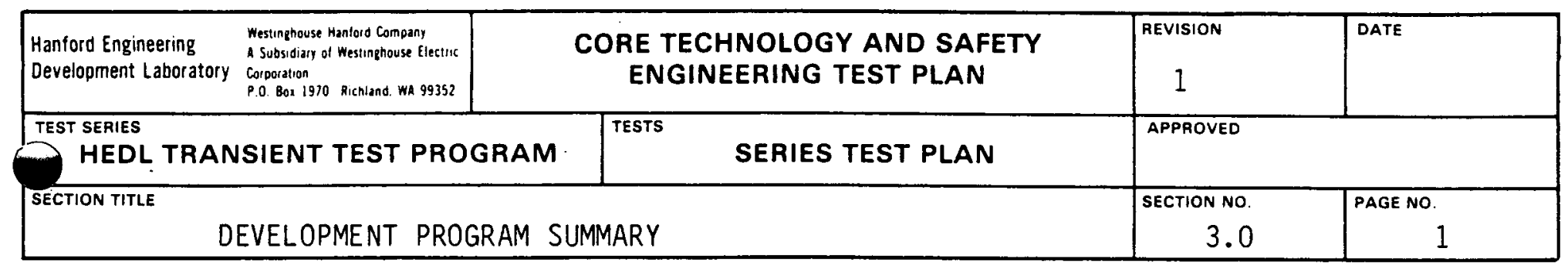

\subsection{DEVELOPMENT PROGRAM SUMMARY}

\subsection{TEST SUMMARY}

The PFR/TREAT Safety Program is a part of the Joint US/UK Safety Test Program which involves transient testing of irradiated and unirradiated fuel pins in the TREAT reactor. Experimental fuel pins fabricated by the US 10.259 in. diameter) and UK (0.230 in. diameter) are to be irradiated in the PFR and then subjected to transient overpower (TOP) or transient undercooling-driver overpower (TUCOP) simulations in TREAT. Pictorials of the US and UK fuel pins are shown in Figures 3.1 .1 and 3.1 .2 , respectively. Other test parameters consist of two power levels and four burnup levels: $0,1 / 3$ goal, $2 / 3$ goal and goal burnup. Goal burnup is $\sim 100,000 \mathrm{MWd} / \mathrm{MTM}$ for the high powered $13 \mathrm{~kW} / \mathrm{ft}$ to $16 \mathrm{~kW} / \mathrm{ft}$ fuel pins and $66,000 \mathrm{MWd} / \mathrm{MTM}$ for the $7 \mathrm{~kW} / \mathrm{ft}$ to $10 \mathrm{~kW} / \mathrm{ft}$ low powered fuel pins. Single pin and multi pin experiments will be conducted. The test objective for single pin experiments is failure time and location determination and for the multi pin experiments the objective is initial fuel dispersal. Table 3.1.1 summarizes the major test parameters for the PFR/TREAT Safety Test Program. Currently, the initial five multi pin experiments L01 through L05 have been assigned to ANL/RAS, and the initial seven single pin experiments $\mathrm{COI}$ through $\mathrm{CO} 7$ have been assigned to HEDL. Experiments $\mathrm{CO}$ through $\mathrm{CO} 3 \mathrm{will}$ be conducted in the static capsule test vehicles, experiments $\mathrm{CO} 4$ and $\mathrm{CO} 5$ will be conducted in modified Mark IIIA loops, and the $\mathrm{CO} 6$ and $\mathrm{C07}$ experiments will be conducted in the single pin test loops (SPTLs).

\subsection{ORGANIZATIONAL RESPONSIBILITIES}

The organizational responsibilities covered under this test plan are as follows:

\subsubsection{Transient Testing (TT)}

a. Overall HEDL PFR/TREAT Safety Test Program planning and coordination. 
FIGURE 3.1 .1

US FABRICATED US/UK SAFETY TEST PROGRAM FUEL PIN

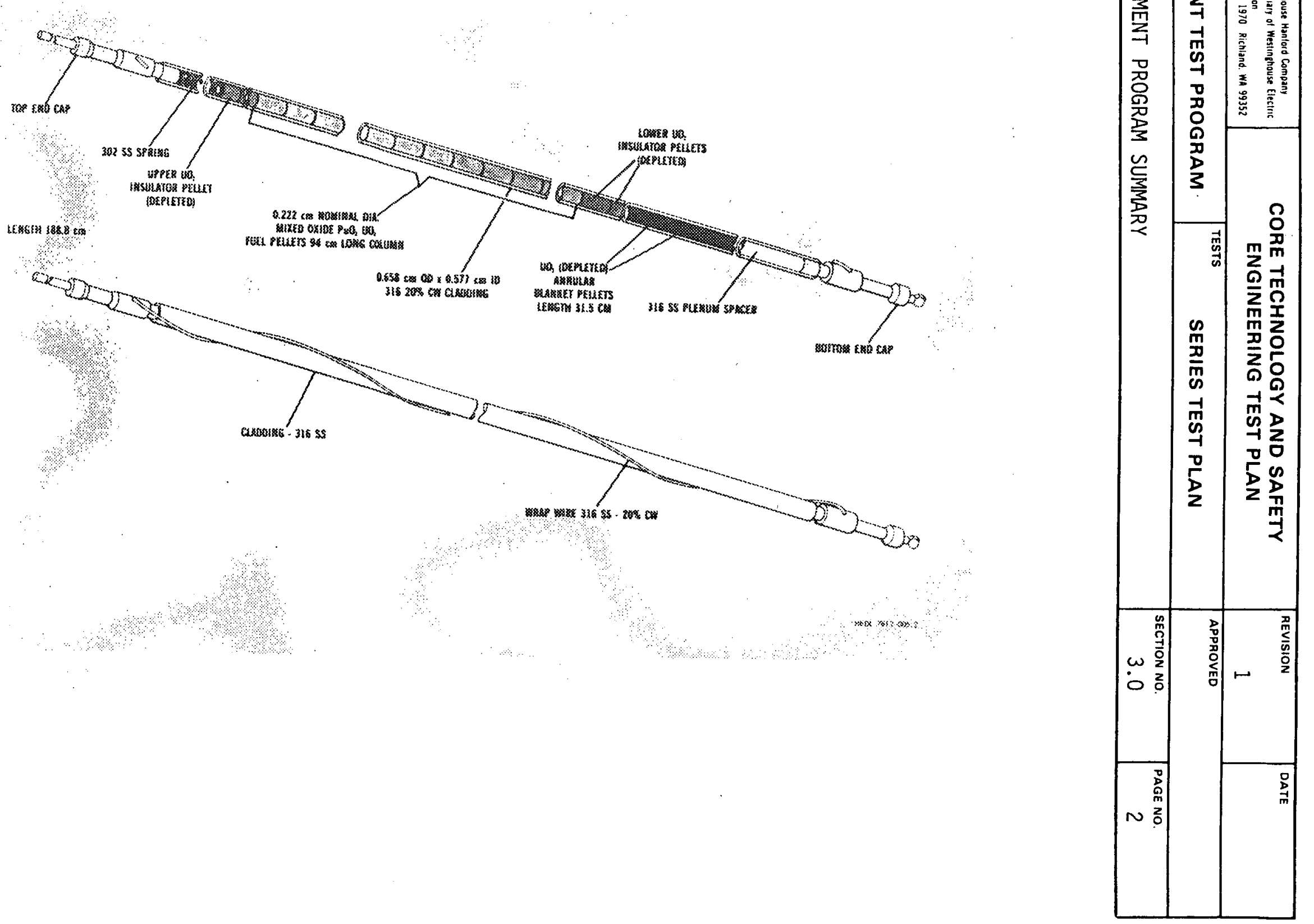


FIGURE 3.1 .2

\section{TYPICAL PFR DRIVER FUEL PIN}

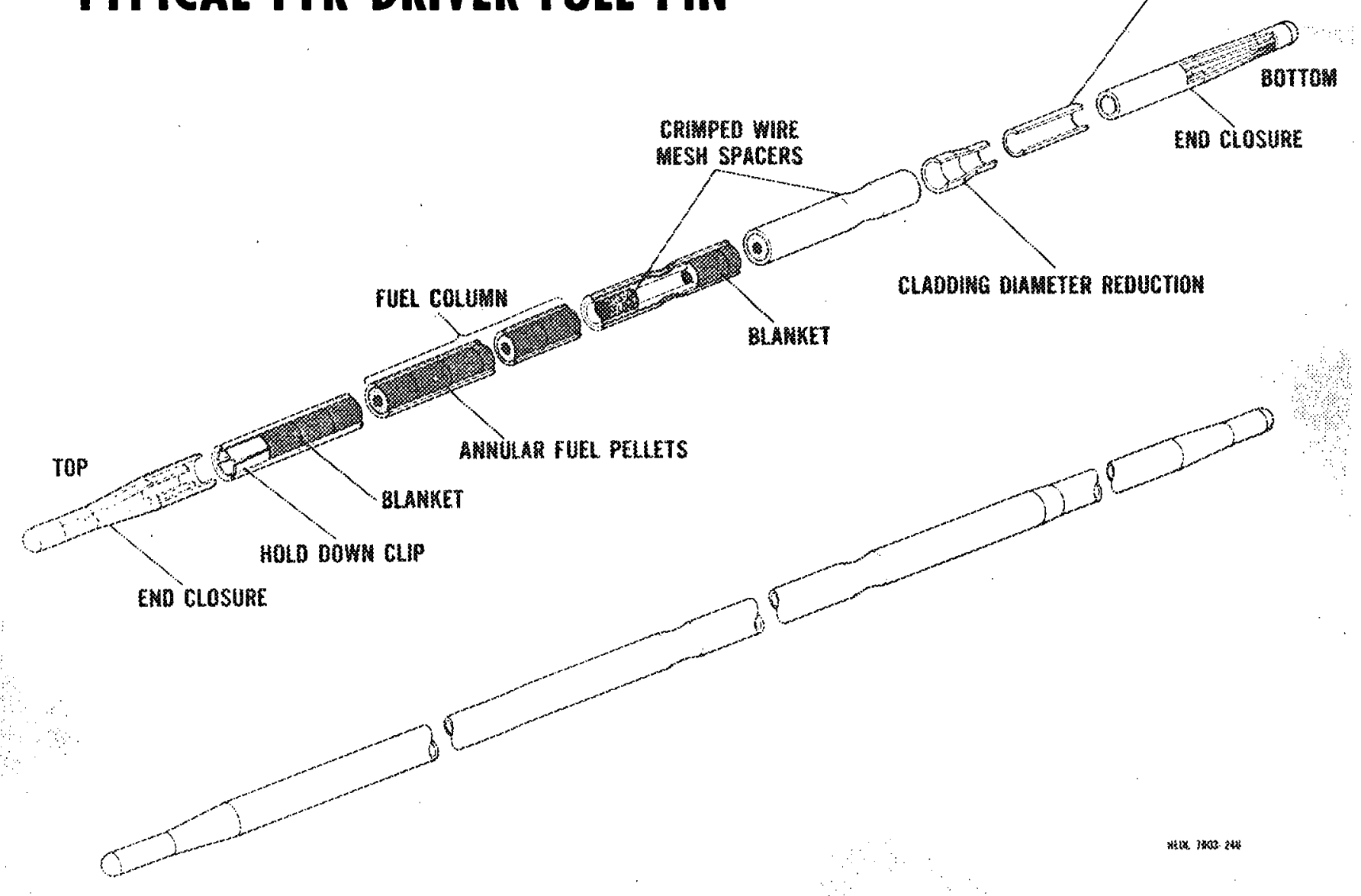


FIGURE 3.1.3 SUMMARY OF PFR/TREAT SAFETY TEST PROGRAM EXPERIMENTS AND TEST PARAMETERS

\begin{tabular}{|c|c|c|c|c|c|c|c|c|c|c|}
\hline \multirow{3}{*}{$\begin{array}{c}\text { TYPE } \\
\text { OF } \\
\text { TRANSIENT }\end{array}$} & \multirow{3}{*}{$\begin{array}{l}\text { FUEL POWER } \\
\text { RATING } \\
\text { (STEADY STATE) }\end{array}$} & \multirow{3}{*}{$\begin{array}{c}\text { TREAT } \\
\text { POWER PULSE } \\
\text { RAMP RATE } \\
\$ / S E C\end{array}$} & \multicolumn{8}{|c|}{ BURNUP } \\
\hline & & & \multicolumn{2}{|c|}{ FRESH } & \multicolumn{2}{|c|}{$1 / 3$} & \multicolumn{2}{|c|}{$2 / 3$} & \multicolumn{2}{|c|}{ FULL } \\
\hline & & & US & UK & US & UK & US & UK & US & UK \\
\hline \multirow{8}{*}{$\begin{array}{c}\text { TRANSIENT } \\
\text { OVER } \\
\text { POWER }\end{array}$} & \multirow{4}{*}{$\begin{array}{c}\text { HIGH } \\
\text { (13-16 KW/FT } \\
\text { PEAK) }\end{array}$} & 5 & & $\begin{array}{l}\mathrm{C}+\mathrm{L} \\
\mathrm{COl} \quad \text { LOl }\end{array}$ & & $\begin{array}{c}\mathrm{C}+\mathrm{L} \\
\mathrm{C02} \quad \mathrm{L} 02\end{array}$ & & & C & $\mathrm{CO}^{\mathrm{C}+\mathrm{L}}$ \\
\hline & & 2 & & & C & & C & & & \\
\hline & & 0.5 & C & & $C+L$ & & C & & $C+L$ & \\
\hline & & SLOW & & L & $L$ & $\begin{array}{c}\mathrm{C}+\mathrm{L} \\
\mathrm{CO}{ }^{\mathrm{L}} \mathrm{O3}\end{array}$ & C & & $C+L$ & $\begin{array}{l}\mathrm{C}+\mathrm{L} \\
\mathrm{C} 05 \\
\end{array}$ \\
\hline & \multirow{4}{*}{$\begin{array}{c}\text { LOW } \\
(7-10 \mathrm{KW} / \mathrm{FT} \\
\text { PEAK) }\end{array}$} & 5 & & & L & $\mathrm{CO6}^{\mathrm{C}+\mathrm{L}}$ & & & C & ${ }_{\mathrm{C} 07}^{\mathrm{C}+\mathrm{L}}$ \\
\hline & & 2 & & & C & & C & & & \\
\hline & & 0.5 & $C$ & & $C+L$ & & C & & $C+L$ & \\
\hline & & SLOW & & & & & C & & $\mathrm{C}$ & \\
\hline \multirow{4}{*}{$\begin{array}{l}\text { TRANSIENT } \\
\text { UNDER- } \\
\text { COOLING } \\
\text { OVER } \\
\text { POWER } \\
\text { (TUCOP) }\end{array}$} & \multirow{2}{*}{$\begin{array}{c}\text { HIGH } \\
\text { (13-16 KW/FT } \\
\text { PEAK) }\end{array}$} & 5 & & $C+L$ & & $\begin{array}{r}C+L \\
\quad L 04 \\
\end{array}$ & $C+L$ & & $C+L$ & $C+L$ \\
\hline & & 2 & & & $C+L$ & & $C+L$ & & $C+L$ & \\
\hline & \multirow{2}{*}{$\begin{array}{c}\text { LOW } \\
(7-10 \mathrm{KW} / \mathrm{FT} \\
\text { PEAK }\end{array}$} & 5 & & $C+L$ & & $\begin{aligned} & C+L \\
& L 05\end{aligned}$ & $C+L$ & & $C+L$ & $C+L$ \\
\hline & & 2 & & & $C+L$ & & $C+L$ & & $C+L$ & \\
\hline
\end{tabular}

LEGEND:

C REFERS TO CAPSULE TEST. COl-CO7 REPRESENT PLANNED SINGLE PIN TESTS TO STUDY FUEL PIN FAILURE TIME.

L REFERS TO LOOP TEST.

LOI-LO5 REPRESENT PLANNED MULTI PIN TESTS TO STUDY FUEL MOTION.

*FULL. (GOAL) BURNUP IS 66 MWD/KG FOR LOW POWER FUEL AND 100 MWD/KG FOR HIGH POWER FUEL. 


\begin{tabular}{|c|c|c|c|c|c|}
\hline $\begin{array}{l}\text { Hanford Engineering } \\
\text { Development Laborator }\end{array}$ & 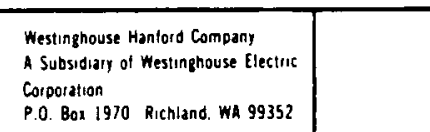 & \multicolumn{2}{|c|}{$\begin{array}{c}\text { CORE TECHNOLOGY AND SAFETY } \\
\text { ENGINEERING TEST PLAN }\end{array}$} & $\begin{array}{c}\text { REVISION } \\
1\end{array}$ & DATE \\
\hline \multicolumn{2}{|c|}{$\begin{array}{l}\text { TEST SERIES } \\
\text { HEDL TRANSIENT TEST PROGRAM }\end{array}$} & TESTS & SERIES TEST PLAN & \multicolumn{2}{|l|}{ APPROVED } \\
\hline \multicolumn{4}{|c|}{ DEVELOPMENT PROGRAM SUMMARY } & $\begin{array}{r}\text { SECTION NO. } \\
3.0\end{array}$ & $\begin{array}{r}\text { PAGE NO. } \\
5\end{array}$ \\
\hline
\end{tabular}

b. Preparation of test vehicle drawings, engineering test plans and addenda.

c. Design of the single pin and multi pin test vehicles and fuel pins.

d. Coordinate the HEDL/ANL-RAS modified Mark IIIA loop activity.

e. Specify the pre- and post-test examination requirements.

f. Conduct PFR steady-state performance analyses.

g. Coordinate fresh and irradiated fuel pin shipments between US and UK.

h. Obtain unirradiated and irradiated fuel pins required for the test program.

i. Preparation of static capsule test article design, drawings and engineering test plans.

j. Coordinate fabrication of static capsule test articles.

k. Perform analys is to establish appropriate test conditions and predict fuel pin performance during the transient test.

1. Preparation of TREAT Guide requirements (safety analys is, test specifications, operating manual, etc.).

m. Coordinate shipping of the test train assembly, fuel pins, and loop to and from the Idaho National Engineering Laboratory (INEL).

n. Prepare the HFEF Processing Specifications for each individual test.

0. Plan and direct postirradiation examination and perform the required post-test analyses, reports, etc.

p. Perform test vehicle stress analyses

q. Review and approve test article designs, design changes and documentation.

r. Conduct TREAT experiments. 


\begin{tabular}{|c|c|c|c|c|c|}
\hline $\begin{array}{l}\text { Hanford Engineering } \\
\text { Development Laborator) }\end{array}$ & 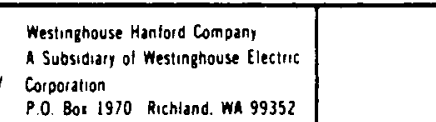 & \multicolumn{2}{|c|}{$\begin{array}{c}\text { CORE TECHNOLOGY AND SAFETY } \\
\text { ENGINEERING TEST PLAN }\end{array}$} & $\begin{array}{r}\text { REVISION } \\
1\end{array}$ & DATE \\
\hline \multicolumn{2}{|c|}{$\begin{array}{l}\text { TEST SERIES } \\
\text { HEDL TRANSIENT TEST PROGRAM }\end{array}$} & TESTS & SERIES TEST PLAN & \multicolumn{2}{|l|}{ APPROVED } \\
\hline \multicolumn{4}{|c|}{ DEVELOPMENT PROGRAM SUMMARY } & $\begin{array}{c}\text { SECTION NO } \\
3.0\end{array}$ & $\begin{array}{c}\text { PAGE NO } \\
6\end{array}$ \\
\hline
\end{tabular}

\subsubsection{Component Fabrication (CF)}

a. Procure, fabricate and assemble the test train and capsule components. (Final assembly of the test train with fuel pins will be performed at the Idaho Facility.)

b. Prepare the test train assembly shipping container.

c. Prepare the requirements and procedures for the assembly of the test articles.

d. Provide unirradiated fuel pins for the Transient Test Program.

\subsubsection{Fabrication and Assembly (F\&A)}

a. Fabricate, assemble, outf it and proof test the flowing coolant loops.

b. Prepare the requirements and procedures for the assembly of the test article.

c. Design and develop the safety test program Annular Linear Induction Pumps (ALIPS) and flow sensors.

d. Prepare for QA approval the fabrication instructions for the loop shipping containers. The loops are to be shipped to the HFEF facility separate from the test train, and routine maintenance will be performed at TREAT. The loops may be returned to HEDL only if re-outfitting is required.

\subsubsection{Postirradiation Testing (PT)}

a. Perform nondestructive and destructive fuel pin examinations in accordance with examination requirements prepared by Transient Testing Section.

b. Remove and reattach test fuel pin wire wraps, when applicable. c. Encapsule fuel pins into TREAT capsules. 


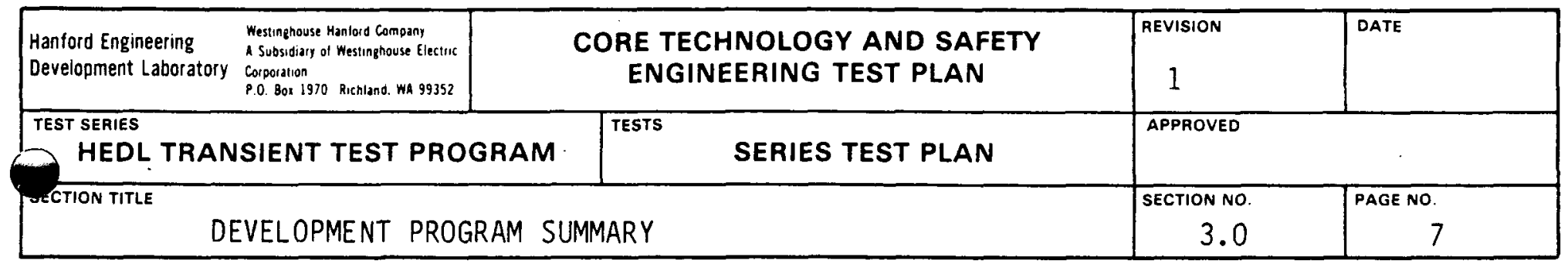

\subsubsection{Fuels Quality Assurance}

\subsubsection{Fuels Quality Engineering (FQE)}

a. Review and approve the design and fabrication documents, ETP, work plans, purchase orders and work instructions.

b. Prepare receiving inspection plans.

c. Perform scheduled audits.

d. Prepare fuel pin sampling plan for the fuel and insulator pellets.

e. Prepare inspection and test plan for fabrication of loop components.

\subsubsection{Fuels Quality Control (FQC)}

Fuels Quality Control shall perform the necessary surveillance and inspection activities to ensure conformance to the appropriate documents and procedures.

\subsubsection{Argonne National Laboratory (ANL)}

\subsubsection{ANL/RAS}

ANL/RAS is responsible for delivery of two operational modified Mark IIIA loops to HFEF for HEDL use. The loops will be fabricated and outfitted to the HEDL technical requirements prepared by Transient Testing.

\subsubsection{HFEF}

The fuel pins are to be loaded and unloaded into the test train and the test train assembly loaded and unloaded into the loop at the Hot Fuels Examination Facilities (HFEF). Depending upon the condition of the test pins, test train and programmatic objectives after the TREAT experiment, the loop may require sectioning and the recovered test section(s) returned to $\mathrm{HEDL}$ for further examination. 


\begin{tabular}{|c|c|c|c|c|c|c|}
\hline $\begin{array}{l}\text { Hanford Engineering } \\
\text { Development Laboratory }\end{array}$ & 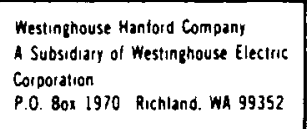 & \multicolumn{3}{|c|}{$\begin{array}{c}\text { CORE TECHNOLOGY AND SAFETY } \\
\text { ENGINEERING TEST PLAN }\end{array}$} & $\begin{array}{c}\text { REVISION } \\
1\end{array}$ & DATE \\
\hline \multicolumn{3}{|c|}{$\begin{array}{l}\text { TEST SERIES } \\
\text { HEDL TRANSIENT TEST PROGRAM }\end{array}$} & TESTS & SERIES TEST PLAN & \multicolumn{2}{|l|}{ APPROVED } \\
\hline \multicolumn{5}{|c|}{ DEVELOPMENT PROGRAM SUMMARY } & $\begin{array}{r}\text { SECTION NO. } \\
3.0\end{array}$ & $\begin{array}{r}\text { PAGE NO. } \\
8\end{array}$ \\
\hline
\end{tabular}

\subsubsection{TREAT}

The TREAT project is responsible for loading and unloading the loop into the reactor and conducting the transient test as described in the test operating manual and test specifications. 


\begin{tabular}{|c|c|c|c|c|c|}
\hline $\begin{array}{l}\text { Hanford Engineering } \\
\text { Development Laboratory }\end{array}$ & 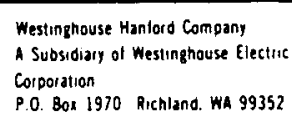 & \multicolumn{2}{|c|}{$\begin{array}{c}\text { CORE TECHNOLOGY AND SAFETY } \\
\text { ENGINEERING TEST PLAN }\end{array}$} & $\begin{array}{r}\text { REVISION } \\
1\end{array}$ & DATE \\
\hline \multicolumn{2}{|c|}{$\begin{array}{l}\text { TEST SERIES } \\
\text { HEDL TRANSIENT TEST PROGRAM }\end{array}$} & TESTS & & \multicolumn{2}{|l|}{ APPROVED } \\
\hline \multicolumn{4}{|c|}{ TEST COMPONENT DESCRIPTION } & $\begin{array}{r}\text { SECTION NO } \\
4.0\end{array}$ & $\begin{aligned} \text { PAGE NO. } \\
1\end{aligned}$ \\
\hline
\end{tabular}

\subsection{TEST COMPONENT DESCRIPTION}

This section contains a brief description of the various components of the single pin test loop experiment apparatus.

\subsection{HEDL SINGLE PIN TEST LOOP (SPTL)}

The HEDL Single Pin Test Loop (SPTL) is a flowing sodium test vehicle designed for transient testing of a single irradiated fuel $p$ in in the TREAT facility. The loop must be capable of containing all tests and test vehicle materials within its boundaries during both normal and abnormal operation conditions. The loop is designed to withstand an integral pressure of 2100 psia at $800^{\circ} \mathrm{F}$ and will be proof-tested to 2625 psia at $800^{\circ} \mathrm{F}$ sodium temperature. The design, fabrication and quality assurance requirements specified in this document for the SPTL meet the intent of the governing RDT standard E16-1, "Test Vehicles for Transient Reactor Test Facility Experiments Containing Sodium."

The functional design requirements for the single pin test loop are as follows:

1) Bas ic Design Requirement that the SPTL be enveloped by the MK-III loop,

2) Utilize MK-III service connections,

3) Variable coolant flow,

4) Prototypic thermal environment,

5) US and UK bottom plenum fuel pins,

6) Inlet and outlet flow sensors,

7) Internal volume to accomodate all pressure pulses,

8) Handling requirements compatible with facility limits,

9) Compatible with the single pin test train design.

The loop is placed in the center of the reactor core and occupies two TREAT fuel element positions. The sodium coolant is pumped up through the test 


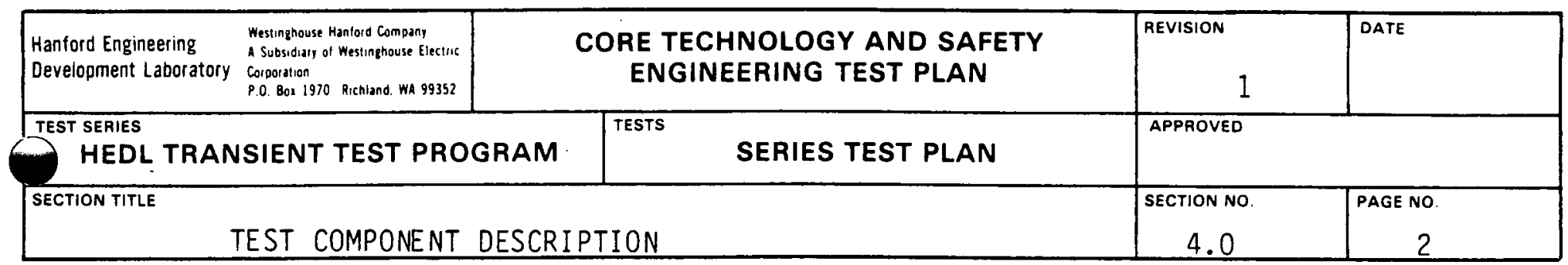

train and recirculated by a single annular linear induction pump. The loop instrumentation consists of monitor and control thermocouples and.inlet and outlet flow sensors. The single pin test train (SPTT) is inserted in the loop through the top closure flange location.

A schematic diagram of the SPTL is shown in Figure 4.1.1, and a cross section at the TREAT core centerline is shown in Figure 4.1.2. The SPTL concept is, basical1y, a modified version of the ANL Mark III series loops. The major difference between the SPTL and the Mark III loop is the SPTL will not require the use of the safety tanks, and only one ALIP will be required for single pin experiment. The single ALIP will be of a similar design as the current Mark III pump.

The Annular Linear Induction Pump (ALIP), which will be used to circulate the sodium coolant in the single pin test loop, will deliver a design volume flow rate of sodium of $6 \mathrm{gpm}\left(3.87 \times 10^{-4} \mathrm{~m}^{3} / \mathrm{s}\right)$ at $427^{\circ} \mathrm{C}$ with a pressure head of $40 \mathrm{psia}\left(2.75 \times 10^{5} \mathrm{~N} / \mathrm{m}^{2}\right.$ ). Total power consumption will be $2.0 \mathrm{~kW}$ (coil winding current of 30 to $35 \mathrm{amps}$ ) at a winding temperature of $250^{\circ} \mathrm{C}$. Net efficiency will be $6 \%$ to $8 \%$, dependent on the winding and sodium temperatures. The pump is a three-phase, four-pole configuration fitting in an envelope of $3.6 \mathrm{in}$. in diameter by $21.25 \mathrm{in}$. 1ong. The pump is composed of three major components: the core, flow duct and stator. The core is a passive component in the sodium flow duct functioning as a magnetic flux return path. It is nominally a $0.80 \mathrm{in}$. diameter rod of cobalt iron tapered at both ends. The flow duct is the test loop pipe, $1.250 \mathrm{in}$. $00 \times 1.07 \mathrm{in}$. ID stainless steel. The stator is isolated from the flow tubes with a high efficiency vacuum-thermos tube insulator. Six stacks of iron laminations and 24 sets of copper coils surround the flow tubes and constitute the field winding. The sealed stator assembly is cooled by silicon oil.

Two permanent magnet flow sensors are used to monitor the sodium flowrate in the test loop. The outlet flow sensors will have a sensitivity of $2 \mathrm{mV}$ per $\mathrm{gpm}$ and a loop coolant pressure loss of $2.2 \mathrm{psia}$ at $6 \mathrm{gpm}$. The inlet flow 


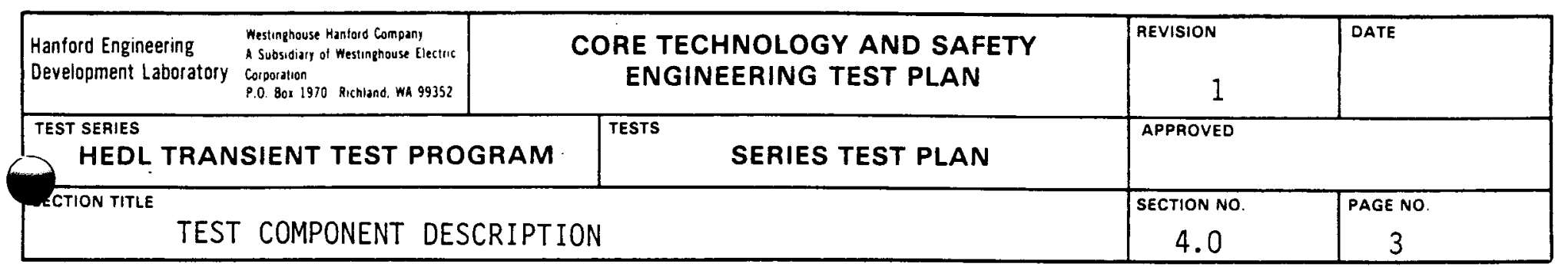

FIGURE 4.1 .1

\section{SCHEMATIC DIAGRAM OF THE SPTL}

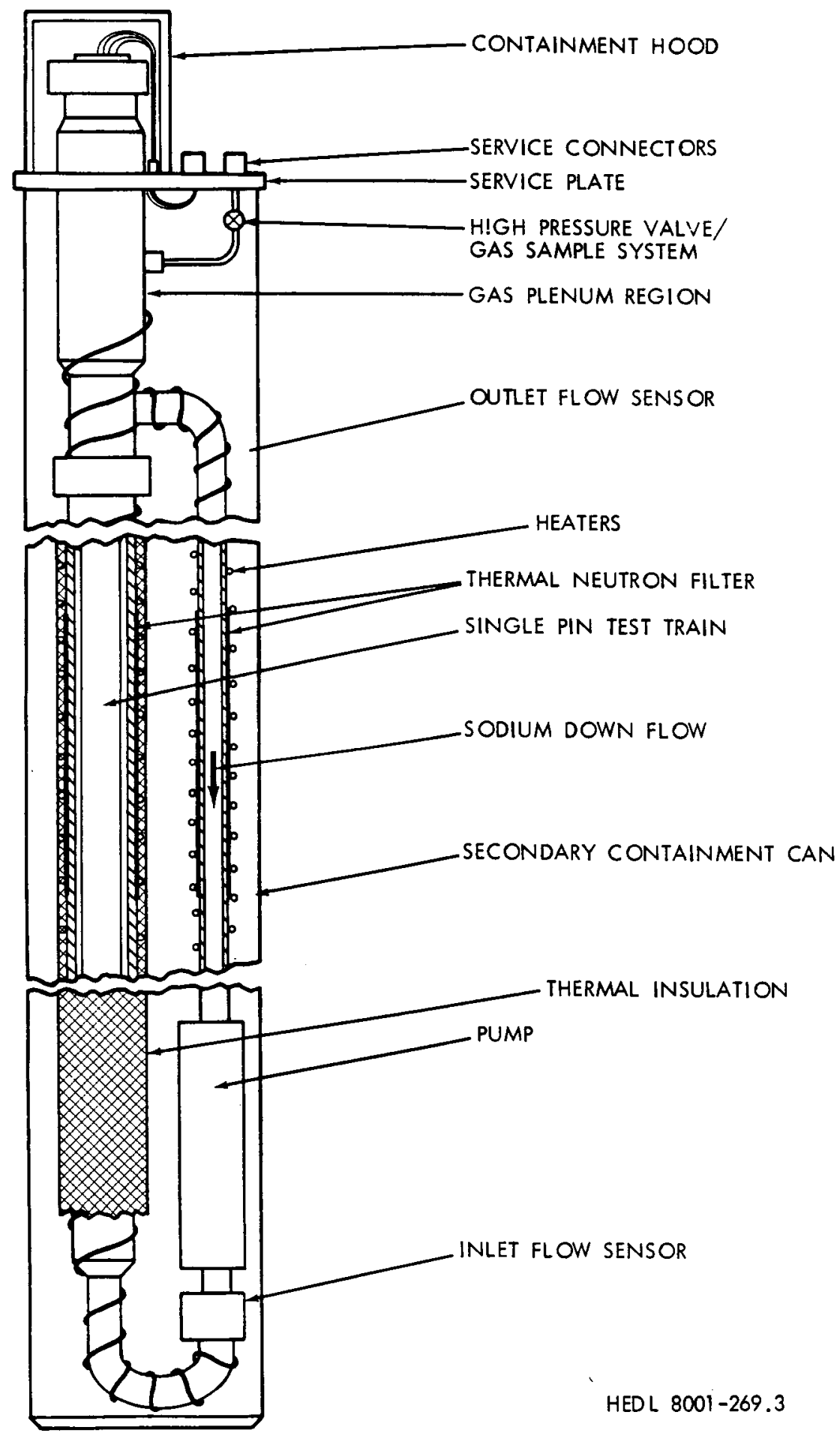




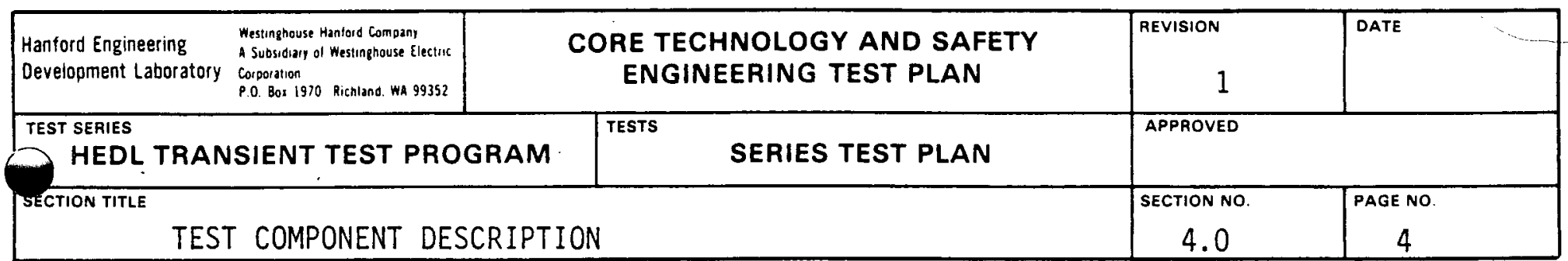

FIGURE 4.1.2

CROSS SECTION OF THE SPTL AT THE TREAT CORE \&

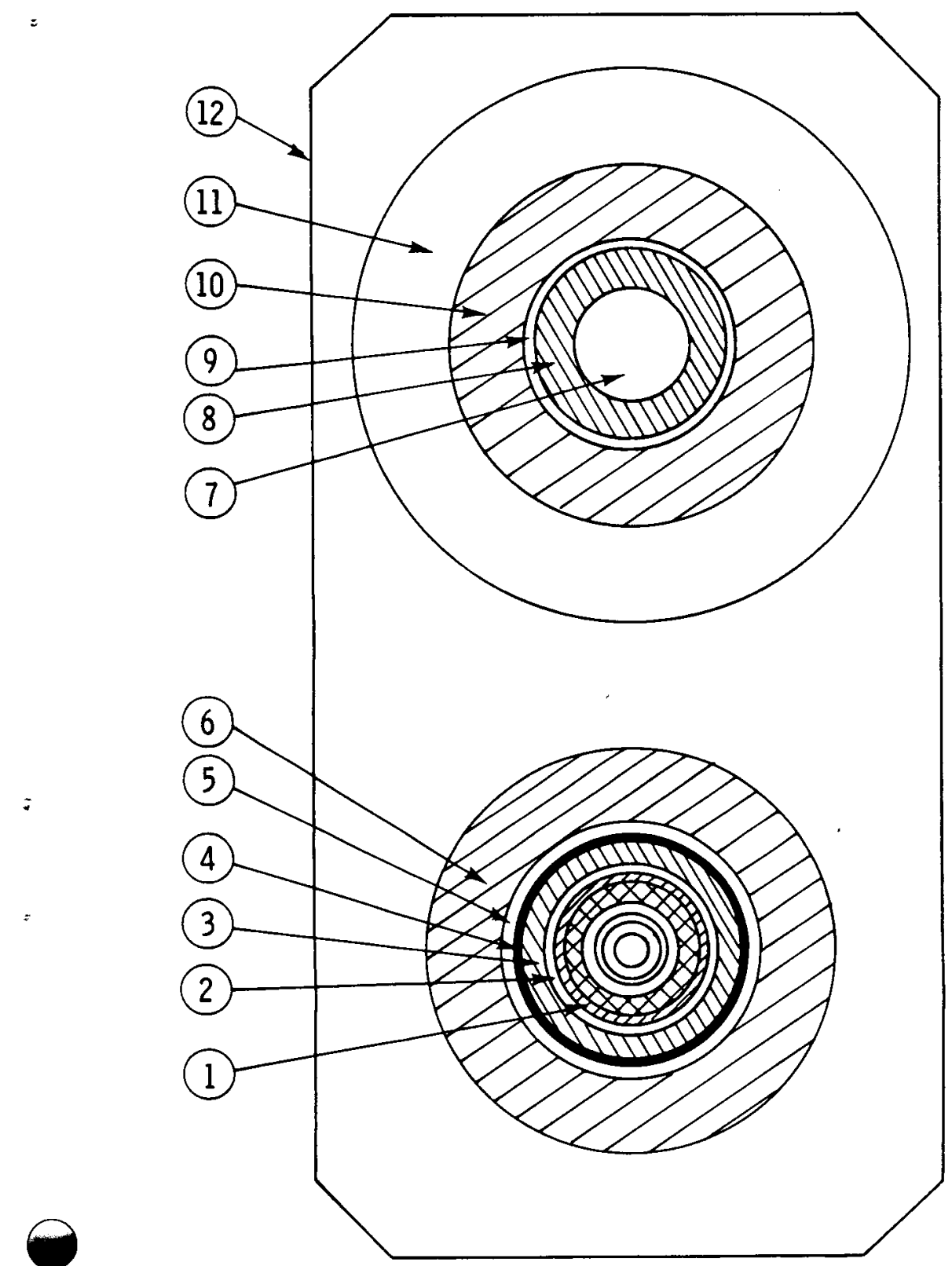

1. SINGLE PIN TEST TRAIN WITH .230 DIA FUEL PIN

2. STAGNANT SODIUM

3. $1.500 D / 1.125$ ID TEST SECTION

4. NEUTRON FILTERS

5. 0.10 DIA HEATERS

6. THERMAL INSULATION

7. SODIUM DOWN FLOW

8. 1.25 OD/.75 ID DOWN LEG

9. 0.10" DIA HEATERS

10. THERMAL INSULATION

11 ALIP

12. $4^{\prime \prime} \times 8^{\prime \prime}$ CONTAINMENT CAN 


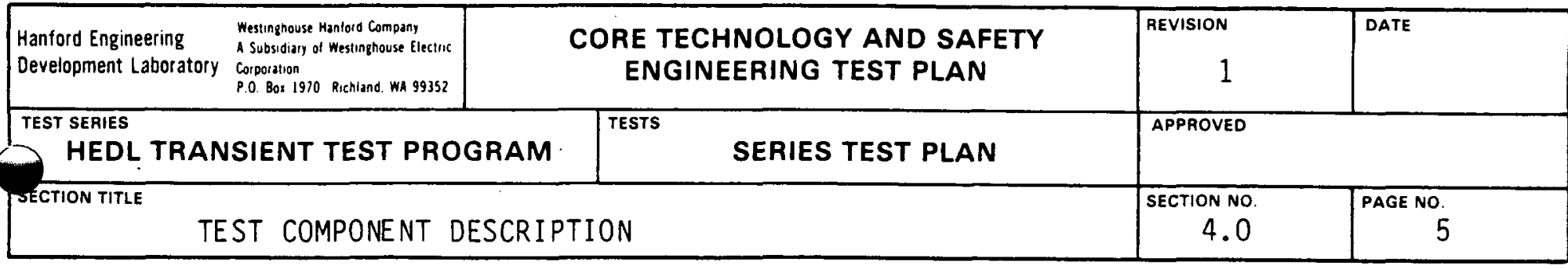

sensor will have a sensitivity of $20 \mathrm{mV}$ per gpm and a loop coolant pressure loss of $4.5 \mathrm{psia}$ at $6 \mathrm{gpm}$. Both flow sensors will use the same configuration $c l a m s h e l l$ Alnico $V$ permanent magnets and $f$ it in a 3 in. $O D \times 5$ in. long envelope.

Sensitivity of the flow sensors are enhanced in three ways. First, large, high energy cobalt-base permanent magnets are used. A soft iron flux concentrator is employed to maximize the magnetic field strength across the flow channel. Secondly, the flow channels will be restricted to maximize the sodium flow velocity and minimize the magnetic gap. Maximizing the flow velocity is essential for high flow sensor sensitivity. Care is taken not to increase the loop coolant pressure losses beyond reasonable limits. Finally, voltage pickups will be located close to the flow channels to minimize signal shunting losses.

\subsection{HEDL SINGLE PIN TEST TRAIN (SPTT) ASSEMBLY}

The test train is a long cylindrical assembly which is inserted into the loop and makes axial contact at the loop's test section seat and the top closure flange (see Figure 4.2.1). Positioned inside the test train is the test element. The test train design must fulfill the following requirements:

1) Position the test element in the loop with respect to the reactor core,

2) Minimize the radial heat losses in the fueled region,

3) Position the test temperature sensors in such a manner to obtain the best test results,

4) All of the coolant flow must be directed past the test element,

5) Allow for differential thermal expansion between the test train and loop,

6) Loop-test train penetrations and seals must be demonstrated to withst and rated loop conditions. 


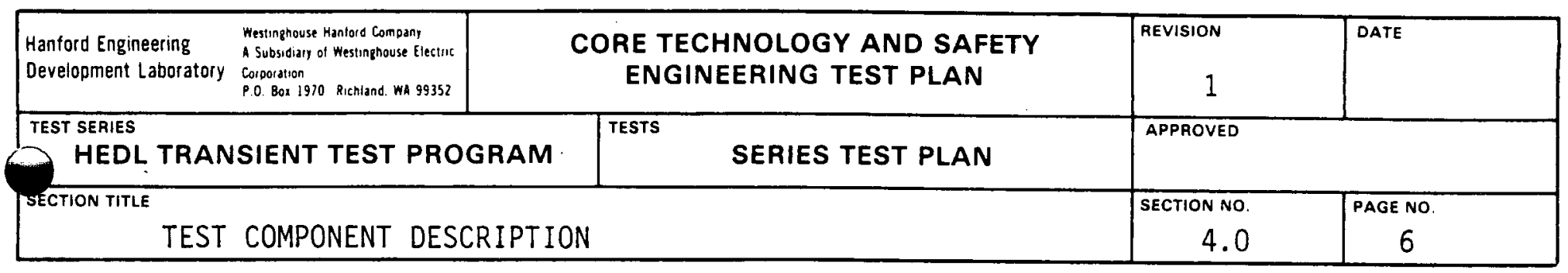

\section{HEDL SINGLE PIN TEST TRAIN}

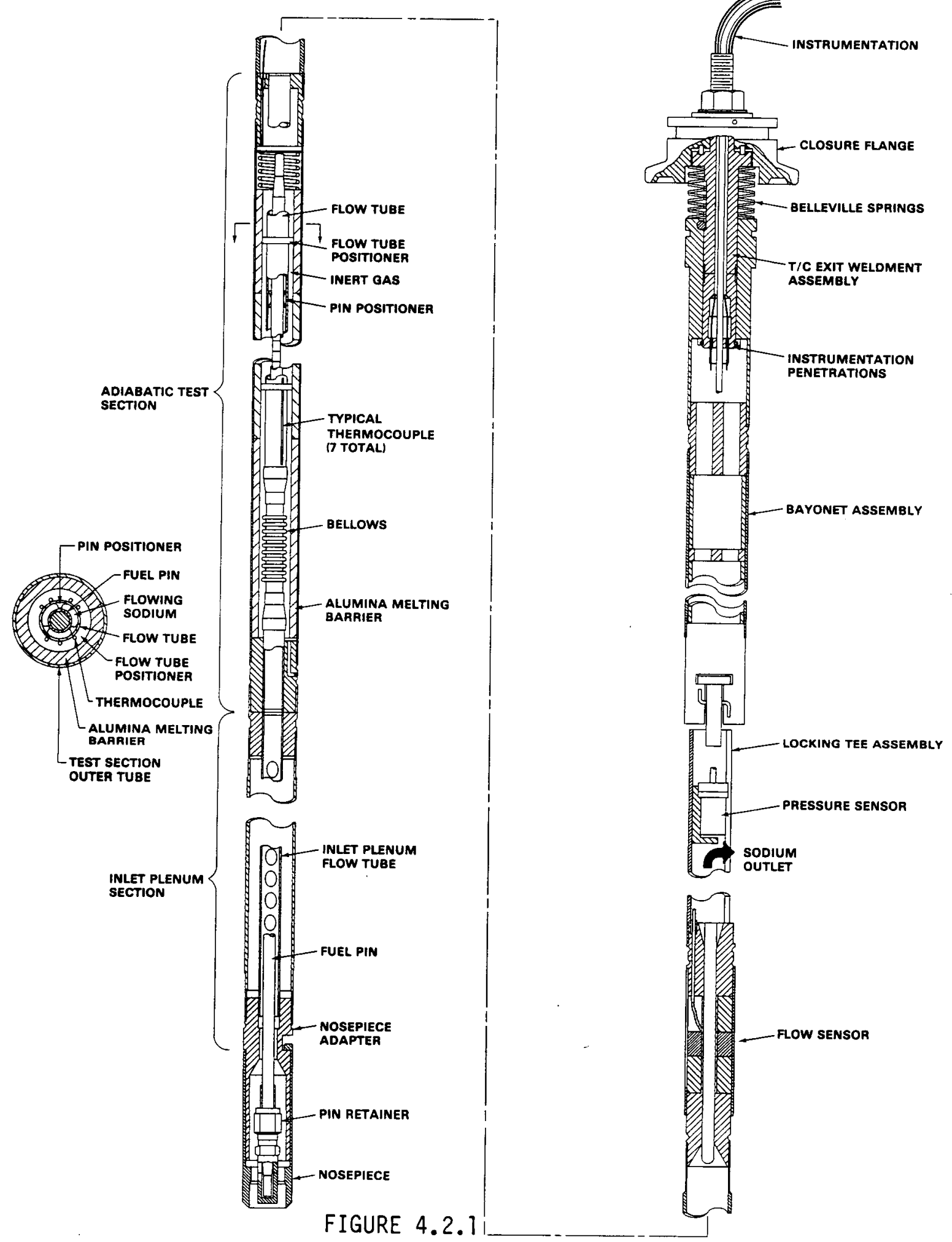

Single Pin Test Train (SPTT) for the HEDL Transient Test Program 


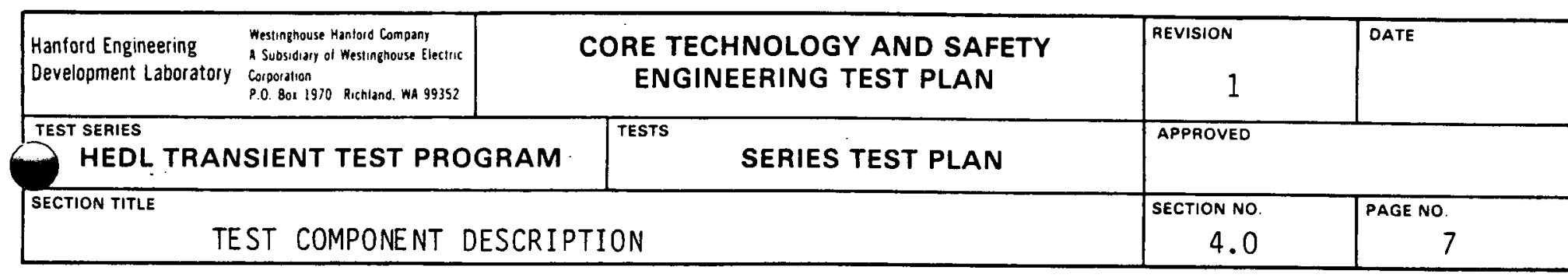

The following is a description of each test train component (see Appendix $C$ for reference to detailed engineering drawings).

\subsubsection{Thermocouple Exit Assembly (Subassembly No. 2)}

The test train thermocouples, the pressure sensor and flow sensor cables exit from the loop pressure boundary through this component. The weldment assembly seal is provided by deforming the metal seal ring against the surface of the closure flange and exit assembly. The deformation force is applied by tightening the hexagonal nut against the Belleville washers and top closure flange. A roll pin is used to keep the proper orientation of the exit weldment assembly with the top closure flange.

The T/C Exit Assembly and its mating part below, the baffle assembly, are attached by means of a retainer ring, as shown in the assembly drawing. This ring functions only when the test train is in tension, as in lifting it. When the test train is installed in the loop, the sealing of the top closure flanges compresses the stack of twelve Belleville springs in series. This compression provides the force to seat the bottom of the test train on the loop seating surface so that all the circulating sodium will be directed past the test element.

\subsubsection{Baffle Assembly (Subassembly No. 3)}

The baffle assembly serves two functions: (1) provide an extension and guide for the lower test assembly, and (2) provide protection to the top closure flange seal and thermocouple weldment assembly seal in the event a sodium hammer should be projected upward against these components. The disc-shaped gussets absorb a portion of the energy of the sodium hammer as it moves upward, thereby reducing the energy available upon impact with the top closure flange. The expansion and compression losses of the fluid also contribute in reducing the impact energy on the top closure flange. 


\begin{tabular}{|c|c|c|c|c|c|}
\hline $\begin{array}{l}\text { Hanford Engineering } \\
\text { Development Laboratory }\end{array}$ & 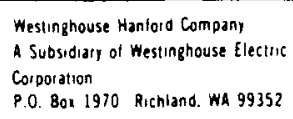 & \multicolumn{2}{|c|}{$\begin{array}{c}\text { CORE TECHNOLOGY AND SAFETY } \\
\text { ENGINEERING TEST PLAN }\end{array}$} & $\begin{array}{r}\text { REVISION } \\
1\end{array}$ & DATE \\
\hline \multicolumn{2}{|c|}{$\begin{array}{l}\text { TEST SERIES } \\
\text { HEDL TRANSIENT TEST PROGRAM }\end{array}$} & TESTS & SERIES TEST PLAN & \multicolumn{2}{|l|}{ APPROVED } \\
\hline \multicolumn{4}{|c|}{ TEST COMPONENT DESCRIPTION } & $\begin{array}{r}\text { SECTION NO. } \\
4.0\end{array}$ & $\begin{array}{r}\text { PAGE NO. } \\
8\end{array}$ \\
\hline
\end{tabular}

The test train assembly orientation is fixed by the bayonet key on the baffle assembly and the index ring attached to the inner wall of the loop closure tube (Drawing No. H-3-47080 Sheet 1, "Single Pin Test Loop Subassembly."

\subsubsection{Bayonet and Pressure Sensor Assembly (Subassembly No. 5)}

This assembly serves a dual purpose. First, it serves as an extension for the test section and directs the flow toward the down leg of the loop. The bayonet mates with the key-way of the baffle assembly and is held in place by two 1/16 in. wires, as shown on the assembly drawing. The tee design provides flexibility in the long test train column, allows the closure flange and seal ring to seal without undue restraint from the test train, and maintains the proper angular orientation with the top of the test train and the loop. The second function is to provide a housing for the outlet pressure sensor (PS-1). The sensor is located just above the beginning of the loop upper bend and is in a good position to detect any pressure pulses from the fueled region without impeding the flow.

\subsubsection{Flow Sensor Assembly (Subassembly No. 6)}

The test train flow sensor assembly, in conjunction with the pole pieces attached to the outside of the loop wall, make up the exit permanent magnet flow sensor. The test train inner pole pieces concentrate the magnetic field across the sodium flow path. There are two sets of signal pickups located in the test train. These are in addition to the pickups on the loop. This proximity to the flow path gives a higher output signal and more accurate measurement of flowrate. The two sets of pickups essentially yield two outlet sensors, and they are to be designated FS-1 and FS-2.

\subsubsection{Test Section Assembly (Subassembly No. 7)}

The purpose of the test section assembly, also called the adiabatic region, is to, (1) provide an insulated boundary to reduce radial heat transfer in 


\begin{tabular}{|c|c|c|c|c|c|c|}
\hline $\begin{array}{l}\text { Hanford Engineering } \\
\text { Development Laboratory }\end{array}$ & 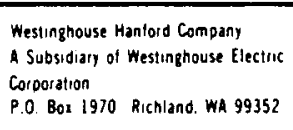 & \multicolumn{3}{|c|}{$\begin{array}{c}\text { CORE TECHNOLOGY AND SAFETY } \\
\text { ENGINEERING TEST PLAN }\end{array}$} & $\begin{array}{r}\text { REVISION } \\
1\end{array}$ & DATE \\
\hline \multicolumn{3}{|c|}{$\begin{array}{l}\text {-TEST SERIES } \\
\text { HEDL TRANSIENT TEST PROGRAM }\end{array}$} & TESTS & SERIES TEST PLAN & \multicolumn{2}{|l|}{ APPROVED } \\
\hline \multicolumn{5}{|c|}{ TEST COMPONENT DESCRIPT } & $\begin{array}{r}\text { SECTION NO. } \\
4.0\end{array}$ & $\begin{array}{r}\text { PAGE NO. } \\
9\end{array}$ \\
\hline
\end{tabular}

the region of heat generation, (2) provide radial support for the fuel element, and (3) position the test train thermocouples. Radial heat transfer losses are effectively reduced by placing an inert gas boundary between the test element coolant flow tube and the alumina molten fuel barrier. This annulus within the outer test train wall is evacuated and back-filled by means of the hole in the lower test section adapter. A bellows is placed in line with the flow tube to compensate for the differential thermal expansion between coolant flow tube and the outer tube. Calculations indicate the maximum differential expansion between the inner and outer tubes is less than the capacity of the bellows.

The radial support of the fuel pin within the flow tube is accomplished with the use of "pin positioners" at several axial locations. These positions have three support pads, spaced $120^{\circ}$ apart and represent the grid-type support in PFR.

Thermocouples are located on the flow tube at various axial fuel column locations to measure the coolant temperature. Experimental data from these thermocouples in conjunction with the coolant flow rate, will be used to establish the thermodynamic behavior of the test element.

\subsubsection{Nose Piece Assembly (Part No. 33, 34 and 36)}

The nose piece makes axial contact with the loop test section seat. The axial force applied to the test train by the action of the Belleville springs provides the seal between the nose piece and the loop test section seat and prevents the sodium coolant from bypassing the test element. The test pin is held in place by a pin retainer made from a SWAGELOK fitting, which clasps the fuel pin bottom end. The nose piece adapter limits movement upward, radially and circumferentially, while the nose piece limits the downward movement. 


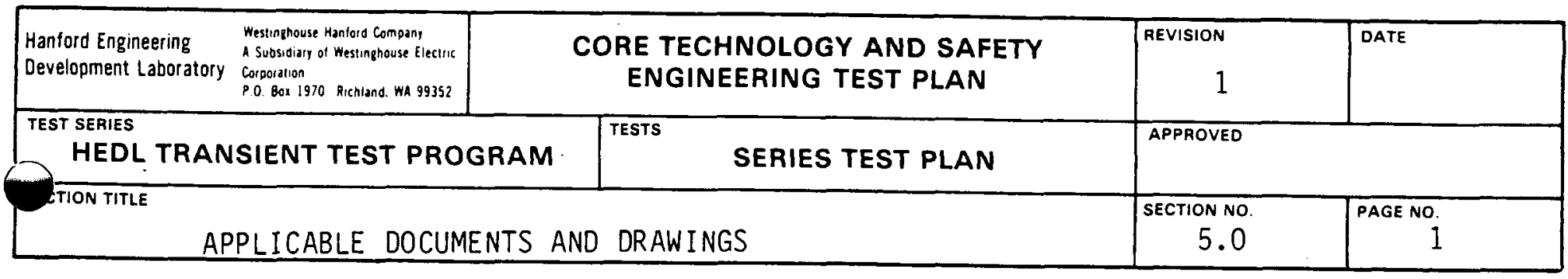

5.0 APPLICABLE DOCUMENTS AND DRAWINGS

\subsection{DOCUMENTS}

The documents 7 isted here are a part of this Engineering Test Plan and shall be applied as specified herein. The documents in force on the date of approval of this document shall apply, including any addenda or amendments in effect on that date unless otherwise specified.

In the event of any conflict between this document and those listed herein, it shall be the responsibility of the organization affected to bring it to the attention of Transient Testing for resolution.

The following documents, where applicable, pertain to the SPTL and the single pin test train assembly for the HEDL Transient Test Program.

\subsubsection{DOE Reactor Development and Technology (RDT) Standards}

$$
\begin{aligned}
& \text { RDT C7-6 - Thermocouple Material and Thermocouple Assembly, Chrome 1-P } \\
& \text { vs. Alumel, Stainless Steel Sheathed, Magnesium Oxide } \\
& \text { Insulated. } \\
& \text { RDT E 15-2NB-T - Class } 1 \text { Nuclear Components (Supplement to ASME Boiler and } \\
& \text { Pressure Vessel Code, Section III, Subsections NA and NB). } \\
& \text { Amendments } 1 \text { through } 4 . \\
& \text { RDT F2-2 - Quality Assurance Program Requirements. } \\
& \text { RDT F2-4 - Quality Verification Program Requirements. } \\
& \text { RDT F3-2 - Calibration Systems Requirements. } \\
& \text { RDT F3-6 - Nondestructive Examination (Supplement to ASME Boiler and } \\
& \text { Pressure Vessel Code, Section V), } 1971 \text { issue. } \\
& \text { RDT F5-1 - Cleaning and Cleanliness Requirements for Nuclear Reactor } \\
& \text { Components. } \\
& \text { RDT F6-2 - Welding of Reactor Core Components and Test Assemblies. } \\
& \text { RDT F6-5T - Welding and Brazing Qualifications (Supplement to ASME } \\
& \text { Boiler and Pressure Vessel Code, Section IX). }
\end{aligned}
$$




\begin{tabular}{|c|c|c|c|c|}
\hline $\begin{array}{l}\text { Hanford Engineering } \\
\text { Development Laboratory }\end{array}$ & $\begin{array}{l}\text { Mestunghouse Hantord Company } \\
\text { A Subsidiary of Westinghouse Electirt } \\
\text { Corpordition } \\
\text { P.0. Box } 1970 \text { Richiand. WA } 99352\end{array}$ & $\begin{array}{c}\text { CORE TECHNOLOGY AND SAFETY } \\
\text { ENGINEERING TEST PLAN }\end{array}$ & $\begin{array}{r}\text { REVISION } \\
1\end{array}$ & DATE \\
\hline $\begin{array}{l}\text { TEST SERIES } \\
\text { HEDL TRAN }\end{array}$ & SIENT TEST PRO & SERIES TEST PLAN & \multicolumn{2}{|l|}{ APPROVED } \\
\hline \multicolumn{3}{|l|}{ SECTION TITLE } & $\begin{array}{r}\text { SECTION NO } \\
5.0\end{array}$ & $\begin{array}{r}\text { PAGE NO. } \\
2\end{array}$ \\
\hline
\end{tabular}

RDT F6-11

- Fabrication and Installation of Piping Subassemblies for Liquid Metal Services

RDT F6-14

- Brazing Fabrication Requirements.

RDT F7-2

- Preparation of Sealing, Packaging, Packing and Marking of Components for Shipping and Storage.

RDT F8-6

- Hoisting and Rigging of Critical Components and Related Equipment.

RDT $M 1-2$

- Stainless Steel Welding Rods and Bare Electrodes (ASME SFA-5.9 with Additional Requirements).

RDT M1-11 - Nickel and Nickel-Alloy Bare Welding Rods and Electrodes (ASME SFA-5.14 with Additional Requirements).

RDT M13-1 - Sodium Purchase Specifications.

RDT M14-1 - Sodium Cover Gas -- Purchase Specifications.

RDT 1-3 - Preparation of Unusual Occurrence Reports.

\subsubsection{American National Standards Institute (ANSI) Standards}

ANSI Y14.5 - Dimensioning and Tolerancing for Engineering Drawings.

\subsubsection{American Society of Mechanical Engineers (ASME)}

ASME SFA-5.14 - Nickel and Nickel-Alloy Base Welding Rods and Electrodes.

ASME Boiler and Pressure Vessel Code, Section III, Subsection NB, Nuclear Power Plant Components, Amendments 1 through 4.

ASME Boiler and Pressure Vessel Code, Section IX, Welding Qualifications, Amendments 1 through 4.

ASME Boiler and Pressure Vessel Code, Section V, Nondestructive Examinations, Amendment 1.

ASME SFA-5.9, Corrosion-Resisting Chromium and Chromium-Nickel Steel Welding Rods and Bare Electrodes.

ASME SA-312, Seamiess Austenitic Stainless Steel Annealed Pipe. 


\begin{tabular}{|c|c|c|c|c|}
\hline $\begin{array}{l}\text { Hanford Engineering } \\
\text { Development Laboratory }\end{array}$ & $\begin{array}{l}\text { Westinghouse Hantord Company } \\
\text { A Subsiolary of Westinghouse Elecritic } \\
\text { Corporation } \\
\text { P. . Bor } 1970 \text { Richland. WA } 99352\end{array}$ & $\begin{array}{c}\text { CORE TECHNOLOGY AND SAFETY } \\
\text { ENGINEERING TEST PLAN }\end{array}$ & $\begin{array}{r}\text { REVISION } \\
1 \\
1\end{array}$ & DATE \\
\hline $\begin{array}{l}\text { TEST SERIES } \\
\text { HEDL TRAN }\end{array}$ & SIENT TEST PRO & SERIES TEST PLAN & \multicolumn{2}{|l|}{ APPROVED } \\
\hline TETION TITLE & APPLICABLE DOCUMENTS AND DRAW INGS & AND DRAW INGS & $\begin{array}{c}\text { SECTION NO. } \\
5.0\end{array}$ & $\begin{array}{c}\text { PAGE NO. } \\
3\end{array}$ \\
\hline
\end{tabular}

5.1.4 American Society for Testing Materials (ASTM)

A-213 - Seamless Ferritic and Austenitic Alloy-Steel Boiler, Superheater, and Heat-Exchanger Tubes.

A-240 - Chromium and Chromium-Nickel Stainless Steel Plate, Sheet, and Strip for Fusion-Welded Unfired Pressure Vessels.

A-269 - Seamless and Welded Austenitic Stainless Steel Tubing for General Service.

A-276 - Stainless and Heat-Resisting Steel Bars Hot-Finished or Cold-Fin ished.

A-312 - Seamless and Welded Austenitic Stainless Steel Pipe.

A-479 - Stainless and Heat Resisting Steel Bars and Shapes for Use in Boilers and Other Pressure Vessels.

B-170 - Oxygen-Free Electrolytic Copper Wire Bars, Billets and Cakes.

B-272 - Flat Copper Products With Finished (Rolled or Drawn) Edges (Flat Wire or Strip).

5.1.5 Aerospace Material Specification (AMS)

AMS-5667F - Alloy, Corrosion and Heat Resistant Nickel Base 15. $\mathrm{Cr}-7 \mathrm{Be}-2.5 \mathrm{Ti}-1(\mathrm{Cb}+\mathrm{Ta})-0.7 \mathrm{Al}$ Bars

5.1.6 HEDL Specifications

5.1.6.1 MG-100 - Quality Assurance Manual

5.1.6.2 Supplemental quality assurance procedures or requirements as specified in Section 14.0 .

5.1.6.3 TA-19 - Packaging

5.1.6.4 TME 72-33 - Operating Procedures for Irradiation Test Fabrication

5.1.6.5 FQE-OP-002 - Instructions for Processing Core Component Nonconformance Reports 


\begin{tabular}{|c|c|c|c|c|}
\hline $\begin{array}{l}\text { Hanford Engineering } \\
\text { Development Laboratory }\end{array}$ & 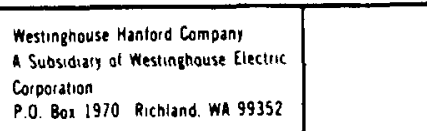 & $\begin{array}{c}\text { CORE TECHNOLOGY AND SAFETY } \\
\text { ENGINEERING TEST PLAN }\end{array}$ & $\begin{array}{r}\text { REVISION } \\
1\end{array}$ & DATE \\
\hline \multicolumn{2}{|c|}{$\begin{array}{l}\text { TEST SERIES } \\
\text { HEDL TRANSIENT TEST PROGRAM }\end{array}$} & SERIES TEST PLAN & \multicolumn{2}{|l|}{ APPAOVED } \\
\hline \multicolumn{3}{|c|}{ APPLICABLE DOCUMENTS AND DRAWINGS } & $\begin{array}{r}\text { SECTION NO } \\
5.0 \\
\end{array}$ & $\begin{array}{r}\text { PAGE NO. } \\
4 \\
\end{array}$ \\
\hline
\end{tabular}

5.1.6.6 TC-1361 - HEDL Mark III Loop Design Confirmation Transient Test Series Engineering Test Plan

\subsubsection{Federal Specifications}

QQ-N-290 - Nickel Plating (Electrodeposited).

QQ-W-423 - Wire, Steel, Corrosion-Resisting.

\subsection{DRAWINGS}

The SPTL and the Single Pin Test Train Design drawings for this test series are specified in Appendices $B$ and $C$ of this document, respectively. Should other HEDL drawings be prepared; shop drawings, outfitting drawings, etc., they shall require the approval of the responsible organizations as specified in Section 3.2, Transient Testing and Fuels Quality Engineering. 


\begin{tabular}{|c|c|c|c|c|}
\hline $\begin{array}{l}\text { Hanford Engineering } \\
\text { Development Laboratory }\end{array}$ & 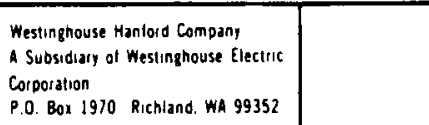 & $\begin{array}{c}\text { CORE TECHNOLOGY AND SAFETY } \\
\text { ENGINEERING TEST PLAN }\end{array}$ & $\begin{array}{r}\text { REVISION } \\
1\end{array}$ & DATE \\
\hline \multicolumn{2}{|c|}{$\begin{array}{l}\text { TEST SERIES } \\
\text { HEDL TRANSIENT TEST PROGRAM }\end{array}$} & SERIES TEST PLAN & \multicolumn{2}{|l|}{ APPROVED } \\
\hline \multicolumn{3}{|c|}{ MATERIAL AND HARDWARE REQUIREMENTS } & $\begin{array}{r}\text { SECTION NO. } \\
6.0\end{array}$ & $\begin{array}{r}\text { PAGE NO. } \\
1\end{array}$ \\
\hline
\end{tabular}

\subsection{MATERIAL AND HARDWARE REQUIREMENTS}

The material and hardware requirements for the loop and test train are specified on the drawings listed in Appendices $B$ and $C$ and supplimented by the contents of this section.

\subsection{LOOP MATERIAL AND HARDWARE REQUIREMENTS}

The appropriate material standards are tabulated in Section 5.0. Use of materials other than those specified on the drawings, or those which fail to meet the specifications of this document, shall require an approved design change. All raw materials which are designated Quality Assurance Level II shall be purchased to the appropriate standards. Materials purchased to a Quality Assurance Level II may be used in a Level III component or assemblies. All raw materials shall require certification by the vendor.

\subsubsection{Pressure Boundary Components}

\subsubsection{Pressure Boundary Raw Materials}

The pressure boundary components are tabulated in Table 6.1.1. The following material requirements pertain to Type 316 stainless steel components of Table 6.1.1.

\section{A. Type 316 Stainless Steel Rods, Bars and Pipe}

ASTM A-47.9, "Stainless and Heat Resisting Steel bars and Shapes for Use in Boilers and Other Pressure Vessels."

ASTM A-276, "Stainless and Heat Resisting Steel Bars and Shapes." Rods and bars shall be fully annealed, center less ground, and have a carbon content $0.04 \% \mathrm{C}$ minimum ( $\mathrm{H}$ grade), and a nickel content $11.0 \% \leq \mathrm{Ni} \leq 14.0 \%$. 


\begin{tabular}{|c|c|c|c|c|}
\hline $\begin{array}{l}\text { Hanford Engineering } \\
\text { Development Laboratory }\end{array}$ & 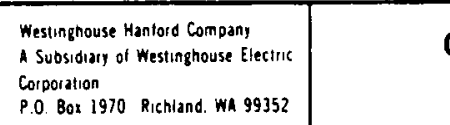 & $\begin{array}{c}\text { CORE TECHNOLOGY AND SAFETY } \\
\text { ENGINEERING TEST PLAN }\end{array}$ & $\begin{array}{r}\text { REVISION } \\
1 \\
1\end{array}$ & DATE \\
\hline $\begin{array}{l}\text { TEST SERIES } \\
\text { HEDL TRAN }\end{array}$ & USIENT TEST PROGRAM & SERIES TEST PLAN & \multicolumn{2}{|l|}{ APPROVED } \\
\hline \multicolumn{2}{|r|}{ MATERIAL AND HARDWARE } & REQU IREMENTS & $\begin{array}{c}\text { SECTION NO. } \\
6.0\end{array}$ & $\begin{array}{r}\text { PAGE NO } \\
2\end{array}$ \\
\hline
\end{tabular}

TABLE 6.1 .1

SPTL PRESSURE BOUNDARY COMPONENTS

Part Number
H-3-47080-3
H-3-47080-4
H-3-47080-5
H-3-47080-6
H-3-47080-7
H-3-47080-8
H-3-47084-2
R0202-0130-DB
RO202-0131-DC
R0202-0206-DB
RO202-0196-DB
ETD-1-56783-B
RP-1-44936-A
H-3-47103-9
H-3-47653-4
H-3-47653-5
H-3-47653-6
H-3-47653-7
H-3-47653-15

\begin{tabular}{l} 
Description \\
\hline Closure Tube \\
Return Tee \\
Return Leg \\
Test Section \\
Trans ition Piece \\
Lower Bend \\
Flow Sensor Tube \\
Closure Flange Bolt \\
Closure Flange Clamp \\
Blind Closure Flange \\
Closure Flange Seal Ring \\
Closure Flange \\
Seal Ring - Thermocouple \\
TC Exit \\
Core Tube \\
Core Tube \\
Core Tube \\
Duct, Lower Flowmeter \\
Core Tube
\end{tabular}

Material Type

316 SST

316 SST

316 SST

316 SST

316 SST

316 SST

316 SST

Inconel $x-750$

Inconel $x-750$

316 SST

316 SST

316 SST

316 SST

316 SST

316 SST

316 SST

316 SST

316 SST

316 SST 


\begin{tabular}{|c|c|c|c|c|}
\hline $\begin{array}{l}\text { Hanford Engineering } \\
\text { Development Laboratory }\end{array}$ & 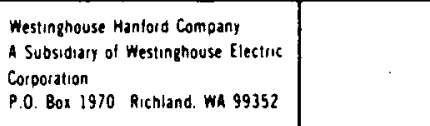 & $\begin{array}{c}\text { CORE TECHNOLOGY AND SAFETY } \\
\text { ENGINEERING TEST PLAN }\end{array}$ & $\begin{array}{r}\text { REVISION } \\
1\end{array}$ & DATE \\
\hline \multicolumn{2}{|c|}{$\begin{array}{l}\text { TEST SERIES } \\
\text { HEDL TRANSIENT TEST PROGRAM }\end{array}$} & SERIES TEST PLAN & \multicolumn{2}{|l|}{ APPROVED } \\
\hline \multicolumn{2}{|c|}{ MATERIAL AND HARDWARE } & REQUIREMENTS & $\begin{array}{r}\text { SECTION NO. } \\
6.0\end{array}$ & $\begin{array}{r}\text { PAGE NO. } \\
3 \\
\end{array}$ \\
\hline
\end{tabular}

B. Type 316 Stainless Steel Plate

ASTM A-240, "Stainless and Heat Resisting Chromium and Chromium-Nickel Stee] Plate, Sheet and Strip for Fusion Welded Unfired Pressure Vessels." Plate shall be fully annealed, and have a carbon content $0.04 \% \leq C \leq 0.08 \%$,

( $H$ grade) and a nickel content $11.0 \% \leq \mathrm{Ni} \leq 14.0 \%$.

C. Type 316 Stainless Steel Tubing

ASTM A-213, "Seamless Ferritic and Austenitic Alloy-Steel Boiler Superheater and Heat-Exchanger Tubes." Tubing shall be cold drawn fully annealed Type $316 \mathrm{H}$ with a carbon content of $0.04 \% \leq \mathrm{C} \leq 0.08 \%$ and a nickel content of $11.0 \% \leq \mathrm{Ni} \leq 14.0 \%$.

ASTM A-269, "Seamless and Welded Austenitic Stainless Steel Tubing for General Service." Tubing shall be fully annealed seamless Type 316 and have a carbon content of $0.04 \% \leq \mathrm{C} \leq 0.08 \%$ and a nickel content of $11.0 \% \leq \mathrm{Ni} \leq 14.0 \%$.

\subsubsection{Material Certification and Inspection Requirements}

A. Certified chemical checks and tensile tests shall be performed on all material used for the Loop. For the pressure boundary components for Table 6.1.1, certification will include separate chemical analyses independent of the supplier's analysis. The chemical analyses and tensile test shall be performed on each heat of tube, round, and bar. The tensile specimen is to be taken adjacent to the sample for chemical analyses.

All welding filler material shall conform to Paragraph NB-2410, Section III of the ASME Code and supplementing documents.

Chemical overchecks on filler material shall be made from each spool of wire and from each box of rod.

B. The raw material to be used for the closure clamp bolts shall be radiographed prior to machining. 


\begin{tabular}{|c|c|c|c|c|}
\hline $\begin{array}{l}\text { Hanford Engineering } \\
\text { Development Laboratory }\end{array}$ & 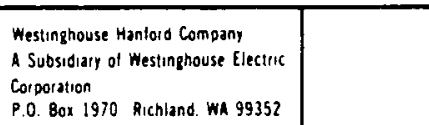 & $\begin{array}{c}\text { CORE TECHNOLOGY AND SAFETY } \\
\text { ENGINEERING TEST PLAN }\end{array}$ & $\begin{array}{r}\text { REVISION } \\
1\end{array}$ & DATE \\
\hline $\begin{array}{l}\text { TEST SERIES } \\
\text { HEDL TRANS }\end{array}$ & ISIENT TEST PROGRAM & SERIES TEST PLAN & APPROVED & \\
\hline \multicolumn{3}{|c|}{ MATERIAL AND HAROWARE REQUIREMENTS } & $\begin{array}{r}\text { SECTION NO. } \\
6.0\end{array}$ & $\begin{array}{r}\text { PAGE NO. } \\
4\end{array}$ \\
\hline
\end{tabular}

C. A coupon from each heat of raw material stock (bar, tube, etc.) procured for the pressure boundary components of Table 6.1 .1 shall receive a fluorescent liquid penetrant test (for information only) in accordance with the requirements of RDT F3-6. In addition, all pressure boundary raw materials shall be submitted to an ultrasonic inspection in accordance with RDT F3-6 as amended below for calibration hole diameter.

AMS 5667F, Grade 688 Type I (Inconel X-750)

U1trasonic inspection shall be made on each bar to the 1971 edition of RDT F3-6 (except 3/16 in. diameter round used for closure flange clamp bails). The standard shall be a flat bottom hole 1/32 in. diameter for rounds and bars. Where high noise level is encountered, due to material structure, a 1/16 in. diameter flat bottom hole may be used. In this case, hole depth shall be $25 \%$ of the material thickness for 2 in. thickness or less; or the greater of $1 / 2$ in. or $10 \%$ of the material thickness of material greater than 2 inches. Material with a reflector equal to or in excess of the reflector from the test holes is cause for rejection.

ASTM A-479-63, Type 316

Ultrasonic inspection shall be made for each bar to the 1971 edition of RDT F3-6 using a standard flat bottom hole 1/32-in. diameter for sizes $3 / 8$ in. to 2-7/8 in. diameter rounds, and a 1/16 in. diameter flat bottom hole for sizes 3-1/4 in. and 3-1/2 in. diameter rounds, and a 1/8-in. diameter flat bottom hole for 4-in. diameter rounds. Material with defects in excess of standard is not acceptable.

ASTM A-312, ASME SA-312, ASTM A-269 and ASTM A-213 Type 316

Ultrasonic inspection shall be made on each pipe and tubing Section NB-2552 of the ASME Boiler and Pressure Vessel Code, Section V, using a standard of the same nominal diameter and thickness and of the same nominal composition 


\begin{tabular}{|c|c|c|c|c|}
\hline $\begin{array}{l}\text { Hanford Engineering } \\
\text { Development Laboratory }\end{array}$ & $\begin{array}{l}\text { Westinghouse Hantord Company } \\
\text { A Subsiduary of Westinghouse Electinc } \\
\text { Copporation } \\
\text { P.O. Box } 1970 \text { Richland. Wa } 99352\end{array}$ & $\begin{array}{c}\text { CORE TECHNOLOGY AND SAFETY } \\
\text { ENGINEERING TEST PLAN }\end{array}$ & $\begin{array}{r}\text { REVISION } \\
1\end{array}$ & DATE \\
\hline TEST SEAIES & ISIENT TEST PROGRAM & SERIES TEST PLAN & \multicolumn{2}{|l|}{ APPROVED } \\
\hline \multicolumn{3}{|c|}{ MATERIAL AND HARDWARE REQUIREMENTS } & $\begin{array}{r}\text { SECTION NO. } \\
6.0\end{array}$ & $\begin{array}{r}\text { PAGE NO } \\
5\end{array}$ \\
\hline
\end{tabular}

and heat treated condition as the pipe or tubing which is being examined. The standard defects shall be axial notches of grooves on the outside and inside surfaces of the standard specimen and shall have a length one inch or less, a width not to exceed $1 / 16$ in., and a depth not greater than the larger of $0.004 \mathrm{in}$. or $5 \%$ of the nominal wall thickness. Material with defects in excess of the standard is not acceptable.

\subsubsection{Material Repair}

Basic materials shall be free of all repairs. Repair of basic material is not permitted.

\subsubsection{Archive Samples}

One 12-in. long (or a 2-1b) archive sample representing each heat of material procured for fabrication of pressure boundary components shall be maintained. Commercially available fittings shall be exempt from this requirement. Archive samples shall be identified as to heat, lot, material, and purchase order number.

\subsubsection{Non-Pressure Boundary Components}

Certified vendor chemical checks and tensile tests shall be performed on all material (including weld wire) used in the loop non-pressure boundary components. No further certification and inspections are required for these materials.

\subsubsection{Hardware Requirements}

The QA level of the hardware components, heaters, thermocouples, nuts, bolts, fittings, etc., are designated on the drawings. Level III components must be equal or better quality than those specified on the drawings. Hardware components shall have vendor supplied certification of physical and chemical properties, or vendor supplied certification that the material complies with the purchase order or verification by chemical overcheck. 


\begin{tabular}{|c|c|c|c|c|}
\hline $\begin{array}{l}\text { Hanford Engineering } \\
\text { Development Laboratory }\end{array}$ & 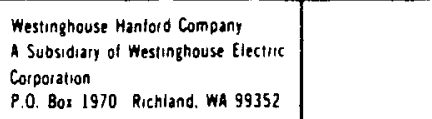 & $\begin{array}{c}\text { CORE TECHNOLOGY AND SAFETY } \\
\text { ENGINEERING TEST PLAN }\end{array}$ & $\begin{array}{r}\text { REVISION } \\
1\end{array}$ & DATE \\
\hline TEST SERIES & SIENT TEST PROGRAM & SERIES TEST PLAN & \multicolumn{2}{|l|}{ APPROVED } \\
\hline \multicolumn{3}{|c|}{ MATERIAL AND HARDWARE REQUIREMENTS } & $\begin{array}{c}\text { SECTION NO. } \\
6.0 \\
\end{array}$ & $\begin{array}{r}\text { PAGE NO } \\
6 \\
\end{array}$ \\
\hline
\end{tabular}

\subsubsection{ALIP and Flow Sensor Requirements}

Material requirements for each component are specified on each drawing. Certified vendor chemical checks shall be performed on all material used in the ALIP and flow sensors. Materials such as clamps, bellows, bolts, screws, fittings, connectors, etc. shall be procured in accordance with applicable manufacturer specifications.

Copper wire shall have a resistivity of less than 1.100 ohm per 1000 feet. Vanadium Permendur rod and flat strip shall be purchased to vendor specification. Macor shall be purchased as a proprietary brand name product. Mullite tubing shall be purchased to vendor specification. Insulating cement shall be Sauereisen $\# 29$ refractory electrically insulating cement purchased to vendor specification. The Permanent Magnets shall be ALNICO V B, conforming to the specification of the Crucible Steel Company of America, ALNICO $\vee$ B permanent magnet alloy.

The pump tube (HEDL drawing H-3-47653) shall be fabricated as a pressure boundary component (paragraph 6.1.1). All other components are non-pressure boundary items. The appropriate material standards are tabulated in Section 5.0 .

\subsection{TEST TRAIN MATERIAL AND HARDWARE REQUIREMENTS}

Material requirements for each component are specified on each drawing and shall require certification. The appropriate material standards are tabulated in Section 5.0. Use of materials other than those specified on the drawings or those which fail to meet the specifications of this document shall require approval of the cognizant Transient Testing Engineer. Itemized herein are the material requirements for the test train assembly components. 


\begin{tabular}{|c|c|c|c|c|}
\hline $\begin{array}{l}\text { Hanford Engineering } \\
\text { Development Laborator }\end{array}$ & 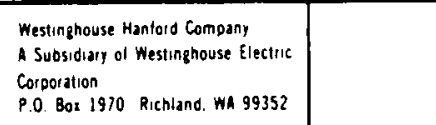 & $\begin{array}{c}\text { CORE TECHNOLOGY AND SAFETY } \\
\text { ENGINEERING TEST PLAN }\end{array}$ & $\begin{array}{r}\text { REVISION } \\
1\end{array}$ & DATE \\
\hline \multicolumn{2}{|c|}{$\begin{array}{l}\text { TEST SERIES } \\
\text { HEDL TRANSIENT TEST PROGRAM }\end{array}$} & SERIES TEST PLAN & \multicolumn{2}{|l|}{ APPROVED } \\
\hline \multicolumn{2}{|r|}{ MATERIAL AND HAROWARE } & REQUIREMENTS & $\begin{array}{r}\text { SECTION NO. } \\
6.0 \\
\end{array}$ & $\begin{array}{r}\text { PAGE NO. } \\
7 \\
\end{array}$ \\
\hline
\end{tabular}

All materials procured to RDT, ASME, ASTM or other material standards shall have vendor certification. Other material shall have vendor certification, or the chemical composition shall be verified by chemical analysis to the specified requirements.

\subsubsection{ASTM A-269 Tubing or Equal Qual ity}

a. Material composition to meet the requirement for grade TP 304 .

b. Seamless or welded tubing.

c. Dimensional requirements as specified on the engineering drawings (Section 5.2 and Appendix C).

d. Test report is required.

\subsubsection{ASTM A-276 Stainless Steel Round Bar Stock}

a. The chemical composition requirements for grade TP 304 or TP 316 shall not exceed the limits specified in the ASTM A-276 standard. Chemical overchecks are required for the elements $\mathrm{C}, \mathrm{Cr}, \mathrm{Ni}$ and $\mathrm{Mo}$ for grade TP 316 .

b. Dimensional requirements as specified on the engineering drawings.

c. Condition A finish.

d. Ladle analysis is required.

e. All bulkhead bar stock shall be leak tested. A helium leak rate greater than $1.0 \times 10^{-9} \mathrm{Scc} / \mathrm{sec}$ constitutes an unacceptable material.

\subsubsection{Flow Sensor Cable}

The flow sensor Bulk Material shall meet the following requirements:

a. Purchased to Specification $Y-131-664$ and RDT Standard C7-6.

b. Four conductor cable with two pair of Chromel-P vs. Alumel wires. 


\begin{tabular}{|c|c|c|c|c|}
\hline $\begin{array}{l}\text { Hanford Engineering } \\
\text { Development Laboratory }\end{array}$ & 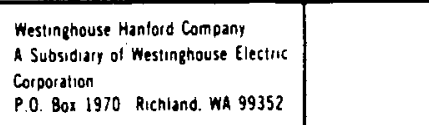 & $\begin{array}{c}\text { CORE TECHNOLOGY AND SAFETY } \\
\text { ENGINEERING TEST PLAN }\end{array}$ & $\begin{array}{r}\text { AEVISION } \\
1\end{array}$ & DATE \\
\hline $\begin{array}{l}\text { TEST SERIES } \\
\text { HEDL TRAN }\end{array}$ & ISIENT TEST PROGRAM & SERIES TEST PLAN & \multicolumn{2}{|l|}{ APPROVED } \\
\hline JECTION TITLE & ATERIAL AND HARDWARE & REQUIREMENTS & $\begin{array}{r}\text { SECTION NO } \\
6.0\end{array}$ & $\begin{array}{r}\text { PAGE NO. } \\
8\end{array}$ \\
\hline
\end{tabular}

c. Outside diameter shall be 0.0625 in. nominal.

d. Stainless steel sheathed and magnesium oxide insulated.

\subsubsection{Thermocouples}

The test train thermocouple Bulk Material shall be purchased to RDT Standard RDT C7-6, Thermocouple Material and Thermocouple Assembly, Chromel-P vs. Alume1, Stainless Steel Sheathed, Magnesium Oxide Insulated.

6.2.4.1 The Bulk Material shall be 0.0625 inch diameter, nominal.

\subsubsection{Bellows}

The bellows shall meet the requirements specified in the HEDL Purchase Order Y-9D-444-70099. Visual inspection, dimensional, and leak test overchecks are required.

\subsubsection{Belleville Springs}

6.2.6.1 The Belleville springs used to provide the nose piece coolant seal shall be $11 / 16$ in. ID $\times 1.375$ in. OD Belleville spring, Associated Spring corporation, Catalog No. B1375-044S, or the equivalent. Each Belleville spring shall meet the following requirements.

a. Chemical composition shall meet the requirements of the government specification MIL-S-5059 Type 302. Vendor certification as to material composition shall suffice.

b. Dimensional requirements as follows:

$$
\begin{aligned}
& \text { ID }-\frac{0.697}{0.692} \text { in. } \\
& 0 D-\frac{1.375}{1.370} \mathrm{in.}
\end{aligned}
$$




\begin{tabular}{|c|c|c|c|c|}
\hline $\begin{array}{l}\text { Hanford Engineering } \\
\text { Deveiopment Laboratory }\end{array}$ & 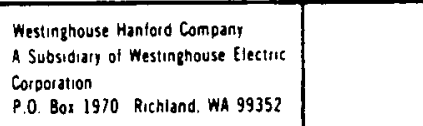 & $\begin{array}{c}\text { CORE TECHNOLOGY AND SAFETY } \\
\text { ENGINEERING TEST PLAN }\end{array}$ & $\begin{array}{r}\text { REVISION } \\
1\end{array}$ & DATE \\
\hline \multicolumn{2}{|c|}{$\begin{array}{l}\text { TEST SERIES } \\
\text { HEDL TRANSIENT TEST PROGRAM }\end{array}$} & SERIES TEST PLAN & \multicolumn{2}{|l|}{ APPROVED } \\
\hline \multicolumn{2}{|r|}{ MATERIAL AND HARDWARE } & REQU IREMENTS & $\begin{array}{r}\text { SECTION NO } \\
6.0\end{array}$ & $\begin{array}{r}\text { PAGE NO. } \\
9\end{array}$ \\
\hline
\end{tabular}

$$
\begin{array}{r}
\text { Height }-\frac{0.089}{0.087} \text { in. } \\
\text { Thickness }-\frac{0.045}{0.043} \text { in. }
\end{array}
$$

c. Load requirements: Each Belleville spring shall be certified that force of $751 \mathrm{~b}-10 \%$ is supplied for a compression distance of $0.0044 \mathrm{in}$. and $375 \mathrm{lb} \cdot 10 \%$ load in the flat position.

6.2.6.2 The Belleville washers used to provide the exit weldment assembly to closure flange seal shall be a $1 / 2$ in. ID $\times 1$ in. OD washer, Associated Spring Corporation, Catalog No. B1000-050S, or the equivalent. Each

Belleville washer shall meet the following requirements:

a. Chemical composition as specified in Section 6.2.6.1a.

b. Dimensional requirements as follows:

$$
\begin{aligned}
& \text { ID }-0.505 \text { in. minimum } \\
& 00-1.000 \text { in. maximum }
\end{aligned}
$$$$
\text { Height }-0.075 \pm 0.005 \text { in } \text {. }
$$

Thickness $-0.050 \pm 0.005$ in.

c. Load requirements: Each Belleville washer shall be certified to show that a load of $600 \mathrm{lb} \pm 10 \%$ is produced in the flat position.

\subsubsection{Pressure Sensor (PS-1)}

The pressure sensor used to detect pressure pulses from failed fuel pins shall be Kaman Sciences Corporation pressure transducer KP-1911-A3000P-SM-C05. The design characteristics of this sensor are:
a. Measures absolute pressure in psi.
b. Pressure range of 5 psi to $3000 \mathrm{psi}$.
c. Standard mounting configuration. 


\begin{tabular}{|c|c|c|c|c|}
\hline $\begin{array}{l}\text { Hanford Engineering } \\
\text { Development Laboratory }\end{array}$ & 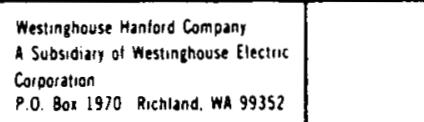 & $\begin{array}{c}\text { CORE TECHNOLOGY AND SAFETY } \\
\text { ENGINEERING TEST PLAN }\end{array}$ & $\begin{array}{r}\text { REVISION } \\
1\end{array}$ & DATE \\
\hline $\begin{array}{l}\text { TEST SERIES } \\
\text { HEDL TRAN }\end{array}$ & ISIENT TEST PROGRAM & SERIES TEST PLAN & \multicolumn{2}{|l|}{ APPROVED } \\
\hline \multicolumn{3}{|c|}{ MATERIAL AND HARDWARE REQUIREMENTS } & $\begin{array}{r}\text { SECTION NO } \\
6.0\end{array}$ & $\begin{array}{r}\text { PAGE NO. } \\
10\end{array}$ \\
\hline
\end{tabular}

d. Metal sheathed cable, mineral insulated cable, $5 \mathrm{ft}$ long.

e. Flexible PVC sheathed cable with transition connector between the two cable sections and connector to electronics housing. The length should be 35 feet.

\section{2 .8 Hexagonal Nut}

A $1 / 2$ - 13 UNC - 2B hex nut, ASTM A307 grade $A$ nut, or better shall be used to tighten the exit weldment assembly to the closure flange. Vendor certification as to material composition shall suffice.

\subsubsection{Flat Washer}

A $1 / 2$ in. ID $\times 1-1 / 4$ in. OD stainless steel flat washer is required in conjunction with the hex nut. Vendor certification as to material composition shall suffice.

\subsubsection{Stainless Wire}

300 series wire $0.062+0.000$ in. 00 shall be used to fix the locking tee to the upper baffle assembly.

\subsubsection{Retaining Ring}

A retaining ring, Waldes Retaining Ring, Catalog No. 5103-68-H, or the equivalent, shall be used to retain the exit weldment assembly.

\subsubsection{Spring Pins}

6.2.12.1 A $3 / 16$ in. nominal diameter $\times 7 / 8$ in. long spring pin, ESNA Catalog No. 79-040-125-0875, shall be used to prevent rotation of the $T / C$ exit adapter and the lower test train assembly with respect to the closure flange. Material shall be certified 300 series stainless steel. 


\begin{tabular}{|c|c|c|c|c|}
\hline $\begin{array}{l}\text { Hanford Engineering } \\
\text { Development Laboratory }\end{array}$ & 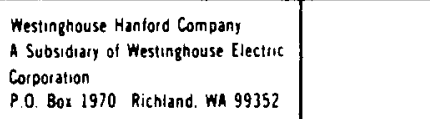 & $\begin{array}{c}\text { CORE TECHNOLOGY AND SAFETY } \\
\text { ENGINEERING TEST PLAN }\end{array}$ & REVISION & DATE \\
\hline $\begin{array}{l}\text { TEST SEAIES } \\
\text { HEDL TRAN }\end{array}$ & SIENT TEST PROGRAM & SERIES TEST PLAN & \multicolumn{2}{|l|}{ APPROVEO } \\
\hline \multicolumn{3}{|c|}{ MATERIAL AND HAROWARE REQUIREMENTS } & $\begin{array}{c}\text { SECTION NO. } \\
6.0\end{array}$ & $\begin{array}{r}\text { PAGE NO. } \\
11\end{array}$ \\
\hline
\end{tabular}

6.2.12.2 A $1 / 8$ in. nominal diameter $\times 7 / 8$ in. long stainless steel spring pin, ESNA Catalog No. 79-028-125-0875, shall be used to prevent rotation of the $T / C$ exit assembly with respect to the closure flange. Material shall be certified 300 series stainless steel or equal quality.

\subsubsection{Thermocouple Connector}

The thermocouple connector for the $\mathrm{CO} 4$ and $\mathrm{CO} 5$ experiments will be provided by ANL. The thermocouple connector for the SPTL experiments, C06, C07---, etc, shall be a Cannon KJ6E-12-35-SN straight plug. The pins shall be the standard gold-silver plated copper alloy. Fabrication and Assembly is to provide the Cannon connector to Component Fabrication.

\subsubsection{Alumina Retaining Spring}

The compression spring used to retain the alumina sleeves in position during shipping and handling shall be Associated Spring Corporation Catalog No. C0850-068-1250-S, or the equivalent. The spring shall satisfy the following requirements.

a. Chemical composition shall meet the requirements of the federal specifications QQ-W-423 Comp. FS302 and AMS 5688 for spring temper. Vendor certification as to material composition shall suffice.

b. The spring shall have a right hand helix and be squared and ground at both ends. The dimensional requirements are given below.

$$
\begin{aligned}
& \text { ID }-0.675 \text { minimum } \\
& 0 D-0.850 \pm 0.015 \\
& \text { Length }-1.25 \pm 0.12 \\
& \text { Wire Diameter }-0.68 \text { nomina } 1 \\
& \text { Spring Rate }-16.5 \pm 10 \% \mathrm{lb} / \mathrm{in} . \\
& \text { Solid Height }-0.39 \text { Reference }
\end{aligned}
$$




\begin{tabular}{|c|c|c|c|c|}
\hline $\begin{array}{l}\text { Hanford Engineering } \\
\text { Development Laboratory }\end{array}$ & 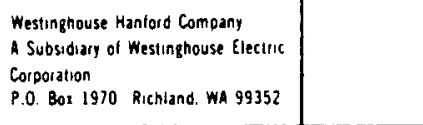 & $\begin{array}{c}\text { CORE TECHNOLOGY AND SAFETY } \\
\text { ENGINEERING TEST PLAN }\end{array}$ & $\begin{array}{r}\text { REVISION } \\
1\end{array}$ & DATE \\
\hline $\begin{array}{l}\text { TEST SERIES } \\
\text { HEDL TRAN }\end{array}$ & SIENT TEST PROGRAM & SERIES TEST PLAN & APPROVED & \\
\hline \multicolumn{3}{|c|}{ MATERIAL AND HARDWARE REQUIREMENTS } & $\begin{array}{r}\text { SECTION NO. } \\
6.0\end{array}$ & $\begin{array}{r}\text { PAGE NO. } \\
12\end{array}$ \\
\hline
\end{tabular}

\subsubsection{Alumina Molten Fuel Barrier}

$$
\text { Composition: } \begin{aligned}
& \mathrm{Al}_{2} \mathrm{O}_{3}-99 \% \\
& \mathrm{SiO}_{2}-0.80 \% \text { maximum } \\
& \mathrm{Fe}_{2} \mathrm{O}_{3}-0.015 \% \\
& \mathrm{Na}_{2} \mathrm{O}-0.050 \% \text { maximum }
\end{aligned}
$$

\subsubsection{Flow Sensor Spacer}

The spacer shall be MACOR, machinable ceramic, made by Dow Corning, or equivalent.

\subsubsection{Pin Retainer}

The pin retainer is made by attaching a cup extension to the bottom of a SWAGELOK To Male Pipe Weld Connector. The SWAGELOK catalog number is SS-400-1-2MPW. The fitting shall be 316 stainless steel, and vendor certification as to material composition shall suffice.

\subsection{TEST PIN REQUIREMENTS}

The pins for tests $\mathrm{CO} 4$ through $\mathrm{CO} 7$ are to be provided by the UK, and HEDL has no responsibility in their fabrication or assembly. 


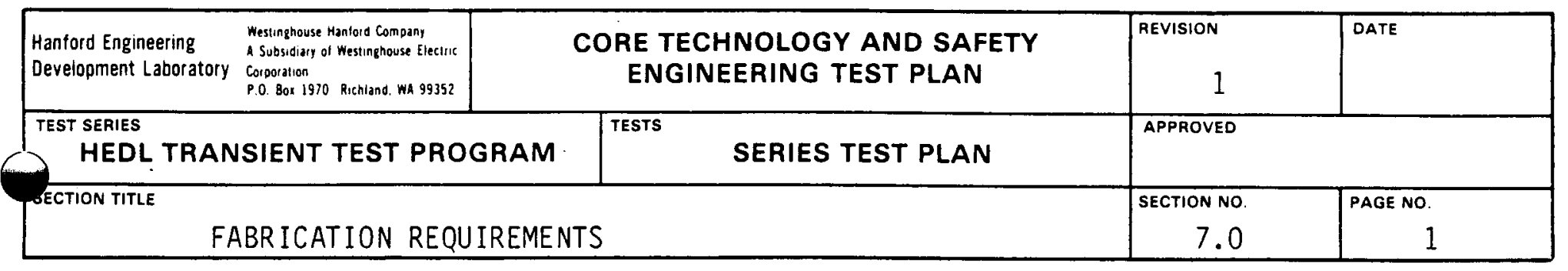

\subsection{FABRICATION REQUIREMENTS}

Fabrication of the test train and loop components shall be in accordance with the drawings and this specification. Work instructions shall be prepared for those components fabricated by HEDL, and off-site fabrication shall be done in accordance with an approved manufacturing plan, instruction or purchase order.

\subsection{LOOP FABRICATION REQUIREMENTS}

7.1.1 All pressure component fabrication shall be done in accordance with Section III of the ASME Boiler and Pressure Vessel Code and with the supplemental requirements of RDT E15-2NB-T and this specification. The applicable code classification is Class I for the pressure boundary components of Table 6.1.1. NPT code symbol marking and Data Report Form NPP-1 are not required. In lieu of NPP-1, the fabricator shall certify that construction of the subassemblies is in accordance with this specification.

7.1.2 Appropriate notes and hold points indicated on the drawings shall be addressed in the work instruction. The cleanliness requirements of Section 9.0 shall be addressed in the work instructions.

7.1.3 Modifications or repairs such as welding, bending, heat treating, cleaning, machining, cutting, temporary attachment, nondestructive testing, or any other process which might alter the function of the loop components, flow sensors or the electromagnetic pump is strictly prohibited uniess specified in this engineering test plan, test plan addenda, approved work plan, or work instructions.

\subsubsection{All components shall conform to the drawing requirements.}

7.1.5 The visual and dimension inspection requirements are to be specified on the inspection requests for each Quality Assurance Level II component. All critical dimensions and geometric dimensions and tolerances (flatness, 


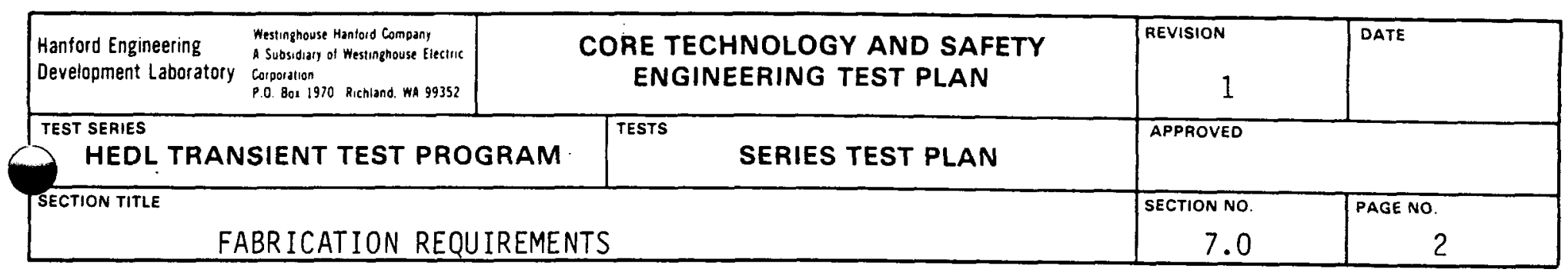

runout, true position, etc.), as specified on the drawings, shall receive $100 \%$ inspection.

7.1.6 Cutting fluids containing more than $50 \mathrm{ppm}$ chlorine and fluorine aggregate shall not be used when machining stainless steel. The final cleaning of components shall use an approved cleaning procedure which has demonstrated the capability of removing soluble chlorides and fluorides to $<0.5 \mu \mathrm{g} / \mathrm{in}^{2}$ Sulfur content of the cutting fluid shall not exceed $1.5 \%$.

7.1.7 All measurements shall be performed with instruments calibrated to RDT Standard RDT F3-2T, Calibration Systems Requirements.

7.1.8 Prior to use in fabrication, all materials shall be examined:

(a) Visually, to assure specified cleanliness and detect obvious defects, and

(b) Nondestructively, in accordance with the requirements specified in Section 6.1 .

7.1.9 Material and component identification and certification shall be traceable.

\subsubsection{Materials}

All materials shall be identified in accordance with the requirements of the applicable material standard. When raw material is cut or sectioned, all identification shall be maintained.

\subsubsection{Components}

During fabrication, all parts shall be identified in accordance with the requirements of RDT F 7-3, except that only marking by electrochemical etching or vibration marking tool shall be used directly on the product. 


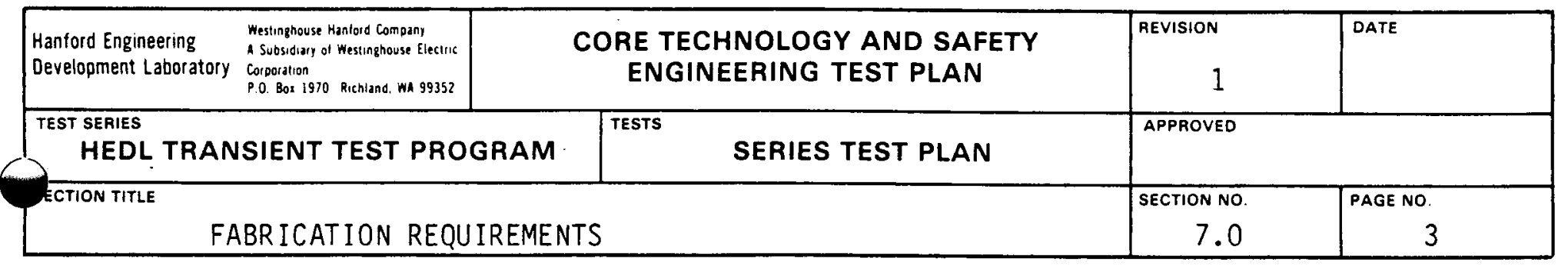

The identification number shall consist of the part drawing number followed by a serial number, $-1,-2,-3$, etc., if more than one identical part is involved. Each component shall be uniquely identified.

7.1.10 Rough machining of the Inconel $\times 750$ bolts shall be done in the solution treated condition. Final machining shall be performed after final age hardening heat treatment.

7.1.11 Clamps shall be final machined after the solution heat treat and prior to final heat treat. Flange clamps shall be machined from bar stock with the central axis of the clamp parallel to the direction of rolling (fibers) of the bar.

7.1.12 The Grade 688 Type I (Inconel X750) closure clamp and bolts shall be heat treated as follows:

A. Prior to final machining, the clamps shall be solution treated at $2100^{\circ} \mathrm{F} \pm 25^{\circ}$ for $3 \mathrm{hrs}$ and rapidly cooled in force-circulated air. A1l surfaces shall then be final machined.

B. After final machining, the clamps shall be stabilized at $1550^{\circ} \mathrm{F} \pm 25^{\circ}$ for $24 \mathrm{hrs}$ or more in vacuum or in a controlled argon atmosphere and furnace cooled in three hours to $1300^{\circ} \mathrm{F}$-or below in vacuum or controlled argon atmosphere.

C. The clamps shall be precipitation hardened at $1300^{\circ} \mathrm{F} \pm 25^{\circ}$ for about $20 \mathrm{hrs}$ in vacuum or in argon atmosphere with cooling in an argon atmosphere.

D. All bolts shall be heat treated at $1750^{\circ} \mathrm{F} \pm 25^{\circ}$ in vacuum for one hour. The furance shall then be brought to $1350^{\circ} \mathrm{F} \pm 25^{\circ}$ and held for eight hours in argon or a vacuum environment. The furnace shall then be cooled to $1150^{\circ} \mathrm{F}$ at a rate of $15^{\circ} \mathrm{F}$ per hour. Thereafter, the furnace shall be cooled in argon or vacuum atmosphere to room temperature.

A coupon consisting of typical material shall be heat treated with the clamps and bolts. The coupon shall be sectioned and metallographically examined. The heat treatment shall be deemed acceptable if the examination verifies that the material has been fully age hardened and a Rockwell hardness between $26 \mathrm{C}$ and $37 \mathrm{C}$. 


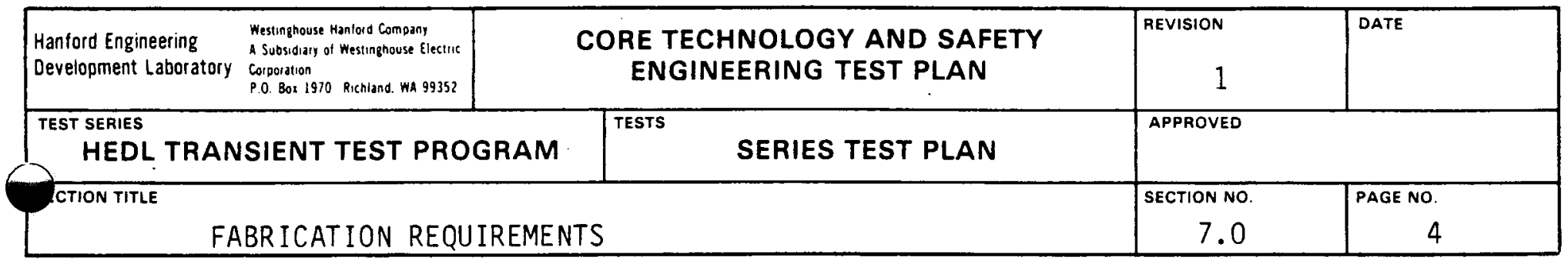

\subsubsection{ALIP and Flow Sensor Fabrication Requirements}

The requirements covered in Paragraph 7.1 .1 through 7.1 .9 do apply to the ALIP and flow sensors.

Special assembly and cleaning procedures for ALIP and flow sensor subassemblies are covered in Section 9 and 10 .

\subsection{TEST TRAIN FABRICATION REQUIREMENTS}

7.2.1 All components shall conform to the geometry and dimensions shown on the drawings.

7.2.2 The visual and dimension inspection requirements are to be specified on the inspection requests for each Quality Assurance Level II component. All critical dimensions and geometric dimensions and tolerances (flatness, runout, true position, etc.), as specified on the drawings, shall receive $100 \%$ inspection.

7.2.3 Cutting fluids containing more than $50^{\circ} \mathrm{ppm}$ chlorine and fluorine aggregate shall not be used when machining stainless steel. The final cleaning of components shall use a cleaning procedure which has demonstrated the capability of removing soluble chlorides and fluorides to less than 0.5 micrograms per inch ${ }^{2}$. Sulfur content of the cutting fluid shall not exceed $1.5 \%$.

7.2.4 Work instructions shall be prepared, and the appropriate notes and hold points indicated on the drawings shall be addressed in the work instruction. Because the length of the test train and the top closure flange dimensions are dependent on the particular loop that is to be used, special precautions shall be taken to ensure the appropriate dimensions are used for the particular test train assembly. 


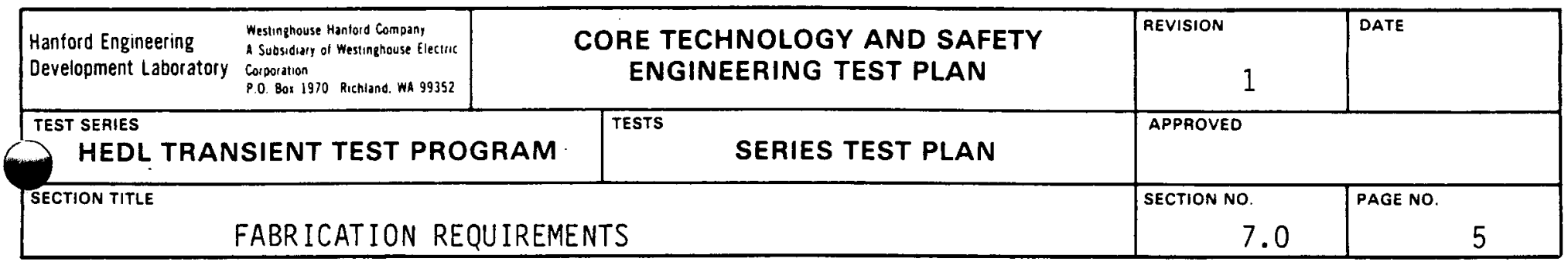

7.2.5 All measurements shall be performed with instruments calibrated to ROT F3-2T, Calibration Systems Requirements.

7.2.6 A fabrication follower card for each component shall be maintained. Material, heat, and/or lot specifications shall be recorded on the follower card.

7.2.7 Some component lengths may require adjustment due to tolerance stack-up as specified in Section 10.2.8 of this ETP.

7.2.8 Special machining of the tube ends may be required since available commercial tubing generally does not meet the required tubing tolerances. Tubing ID to be machined round are to be held in a collet with the appropriate end supported as needed. Record the finished diameter to within an accuracy of \pm 0.001 in. before releasing from the collet. This is the dimension from which the diametral clearance between the tube and mating part shall be determined. The final tubing dimension must meet the print specification. If the wall thickness is too thin, the tube shall be scrapped. If machining of the outside surface is required, the machined surface is to be blended to the unmachined surface with a minimum of a $1 / 8$ in. radius.

7.2.9 Alignment of each component at assembly shall be accomplished by aligning all the $0^{\circ}$ scribe lines placed on the components according to the drawings. For information, the $0^{\circ}$ scribe lines are oriented opposite the direction of the sodium exit flow at Part No. 5 and the loop return leg.

7.2.10 Material and component identification and certification shall be traceable.

7.2.11 Fabrication and Assembly shall provide to Component Fabrication the material for the pressure boundary components of the test train; that is, the top closure flange, the seal ring, and the T/C Exit Part No. 9. 


\begin{tabular}{|c|c|c|c|c|}
\hline $\begin{array}{l}\text { Hanford Engineering } \\
\text { Development Laboratory }\end{array}$ & 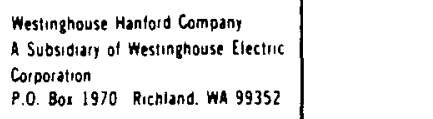 & $\begin{array}{l}\text { ORE TECHNOLOGY AND SAFETY } \\
\text { ENGINEERING TEST PLAN }\end{array}$ & $\begin{array}{r}\text { REVISION } \\
1 \\
1\end{array}$ & DATE \\
\hline $\begin{array}{l}\text { TEST SERIES } \\
\text { HEDL TRAN }\end{array}$ & SIENT TEST PROGRAM & SERIES TEST PLAN & \multicolumn{2}{|l|}{ APPAOVED } \\
\hline \multicolumn{3}{|c|}{ FABR ICATION REQUIREMENTS } & $\begin{array}{c}\text { SECTION NO } \\
7.0\end{array}$ & $\begin{array}{r}\text { PAGE NO } \\
6\end{array}$ \\
\hline
\end{tabular}

a. Component Fabrication shall fabricate the top closure flange to Drawing No. ETD-1-56783-B and the material specification of section 6.1 .1 .1 of this ETP.

b. Component Fabrication shall fabricate the $T / C$ exit seal ring to ANL Drawing No. RP-1-44936-A and the material specification of Section 6.1 .1 .1 of this ETP.

c. Component Fabrication shall fabricate the T/C Exit component, $H-3-47103-9$, and the material specification of Section 6.1.1.1 of this ETP.

\subsection{TEST ELEMENT FABRICATION REQUIREMENTS}

The pins for tests $\mathrm{CO} 4$ through $\mathrm{CO} 7$ are to be provided by the UK, and HEDL has no responsibility for their fabrication. 


\begin{tabular}{|c|c|c|c|c|}
\hline $\begin{array}{l}\text { Hanford Engineering } \\
\text { Development Laboratory }\end{array}$ & 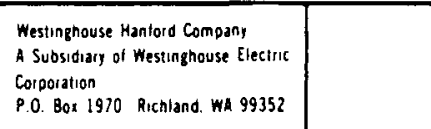 & $\begin{array}{c}\text { CORE TECHNOLOGY AND SAFETY } \\
\text { ENGINEERING TEST PLAN }\end{array}$ & $\begin{array}{r}\text { REVISION } \\
1\end{array}$ & DATE \\
\hline $\begin{array}{l}\text { TEST SERIES } \\
\text { HEDL TRAI }\end{array}$ & ISIENT TEST PROGRAM & SERIES TEST PLAN & \multicolumn{2}{|l|}{ APPROVED } \\
\hline WETION TITLE & LDING REQUIREMENTS & & $\begin{array}{r}\text { SECTION NO. } \\
8.0\end{array}$ & $\begin{array}{r}\text { Page no. } \\
1\end{array}$ \\
\hline
\end{tabular}

\subsection{WELDING REQUIREMENTS}

All welding on the loops and Test Trains shall be in accordance with the drawings and this document. Work instructions or procedures are to be prepared by the organization responsible for the welding. Any hold points designated on the drawings, work plan, or specified herein shall be addressed in the procedures.

\subsection{LOOP WELDING REQUIREMENTS}

\subsubsection{General Requirements}

Welding shall meet the requirements of Section III of the ASME Boiler and Pressure Vessel Code as supplemented by RDT E15-2NB-T.

Only concave fillet welds shall be permitted. The concavity of the fillet welds shall conform to Figure NB-4427-1 of the Code.

\subsubsection{Weld Qualification and Records}

Qualification of the welding procedures to be used and of the performance of welders and welding operators shall comply with the requirements of the Code as supplemented by RDT E15-2NB-T and RDT F6-5. The fabricator's records shall comply with Paragraph NA-4900 of the Code, except that the fabricator will also include a record of joints and the identity of the welding operator making the joints as a part of documentation requirements.

\subsubsection{Single $P$ in Test Loop Subassembly $(H-3-47080)$}

\subsubsection{Pressure Boundary Welding}

The subassembly shall be assembled by Gas Tungsten Arc Welding (GTAW). All weldments are subject to the following additional requirements except for the Top Plate and Magnet Brackets. 


\begin{tabular}{|c|c|c|c|c|}
\hline $\begin{array}{l}\text { Hanford Engineering } \\
\text { Development Laboratory }\end{array}$ & 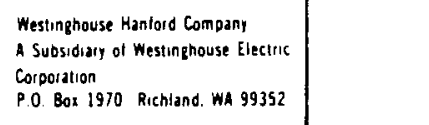 & $\begin{array}{c}\text { CORE TECHNOLOGY AND SAFETY } \\
\text { ENGINEERING TEST PLAN }\end{array}$ & $\begin{array}{r}\text { REVISION } \\
1\end{array}$ & DATE \\
\hline \multicolumn{2}{|c|}{$\begin{array}{l}\text { TEST SERIES } \\
\text { HEDL TRANSIENT TEST PROGRAM }\end{array}$} & SERIES TEST PLAN & \multicolumn{2}{|l|}{ APPROVED } \\
\hline \multicolumn{2}{|r|}{ WELDING REQUIREMENTS } & & $\begin{array}{r}\text { SECTION NO } \\
8.0 \\
\end{array}$ & $\begin{array}{r}\text { PAGE NO. } \\
2 \\
\end{array}$ \\
\hline
\end{tabular}

(a) All welding shall be performed in a clean area as defined in RDT F5-IT, Section 3.4.

(b) GTAW shall be done using ER-316 or ER-308 filler weld material with internal inert gas backup.

(c) Complete joint penetration of wall thickness shall be achieved without undercut or other defects specified in the referenced documents.

(d) The concavity in the weld region on the internal surface of welds $W-3, W-4$ and $W-5$ shall be controlled so that the internal surface can be machined to the straightness, finish and wall thickness shown on drawings.

(e) The concentricity (run out) between adjacent components shal1 not be greater than the dimensional tolerances shown on the drawing.

(f) All finish external weld surfaces shall be filed smooth and fully blended with mating surfaces before any examinations (radiographic, leak and liquid penetrant) are made.

The crown of the weld shall meet the dimensions specified in the Code, Paragraph NB-4426.1.

(g) Length of the lower bend ( $\mathrm{H}-3-47080-8)$ shall be adjusted at final assembly. Welds $W-8$ and $W-9$ are to be the final subassembly welds and are to be welded in conjunction.

\subsubsection{Minor Attachment Welds}

Welds $W-1, W-2, W-10, W-11, W-12, W-13, W-14, W-16, W-17$ and $W-18$ are classified as minor attachment welds in accordance with NB-4435 (RDT E15-2NB-T, Paragraph ANB 5260) and shall be welded in accordance with Section 8.1.3.1, Items $a$ and $b$.

\subsubsection{Weld Repair (During Fabrication)}

(a) Fabricator shall meet Code requirements for weld repair.

(b) Two weld repairs may be performed without further approval. Thereafter, the third repair shall be reported as a nonconformance requiring disposition. A rework repair procedure shall be required prior to repair of the weld. 


\begin{tabular}{|c|c|c|c|c|}
\hline $\begin{array}{l}\text { Hanford Engineering } \\
\text { Development Laboratory }\end{array}$ & 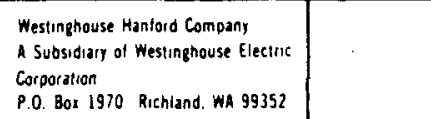 & $\begin{array}{c}\text { CORE TECHNOLOGY AND SAFETY } \\
\text { ENGINEERING TEST PLAN }\end{array}$ & $\begin{array}{r}\text { REVISION } \\
1\end{array}$ & DATE \\
\hline \multicolumn{2}{|c|}{$\begin{array}{l}\text { TEST SERIES } \\
\text { HEDL TRANSIENT TEST PROGRAM }\end{array}$} & SERIES TEST PLAN & \multicolumn{2}{|l|}{ APPROVED } \\
\hline WELDING REQUIREMENTS & ELDING REQUIREMENTS & & $\begin{array}{r}\text { SECTION NO. } \\
8.0\end{array}$ & $\begin{array}{r}\text { PAGE NO. } \\
3\end{array}$ \\
\hline
\end{tabular}

Defects shall be removed by machining or rotary filing only. Grinding and flame cutting are specifically prohibited.

\subsubsection{Dissimilar Metal Welds}

Welds joining dissimilar metals, excluding the use of ER-308 as noted 8.1.3.1.b, shall not be permitted unless specifically authorized in writing by Transient Testing. This provision shall include temporary attachments, such as handling attachments and shop tooling.

\subsubsection{Examination and Testing of Welds}

All weld surfaces should be prepared for inspection in accordance with the requirements of $8.1 .3 .1 . f$. All nondestructive examinations shall be performed according to the methods defined in the code as supplemented by RDT E15-2 and as specified herein. Welds $W-3, W-4, W-5, W-6, W-7, W-8, W-9$ and $W-15$ are designated as critical welds and shall be volumetrically examined by one nondestructive method.

Each weld shall receive radiographic and liquid penetrant examinations. The root and each successive weld pass shall receive liquid penetrant examinations.

\subsection{Visual Examination}

Welded joints and repair welds shall be visually inspected for compliance with the Code and RDT E-15-2NB-T. Dimensional inspection of the welds shall be based upon a reference line, which is permanently marked on the material at a known distance from the joint.

\subsection{Liquid Penetrant Examination}

The liquid penetrant examination shall be made in accordance with Section III of the ASME Code and RDT E-15-2NB-T. 


\begin{tabular}{|c|c|c|c|c|}
\hline $\begin{array}{l}\text { Hanford Engineering } \\
\text { Development Laboratory }\end{array}$ & 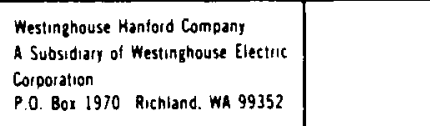 & $\begin{array}{c}\text { CORE TECHNOLOGY AND SAFETY } \\
\text { ENGINEERING TEST PLAN }\end{array}$ & $\begin{array}{r}\text { REVISION } \\
1\end{array}$ & DATE \\
\hline $\begin{array}{l}\text { TEST SERIES } \\
\text { HEDL TRAN }\end{array}$ & ISIENT TEST PROGRAM & SERIES TEST PLAN & \multicolumn{2}{|l|}{ APPROVED } \\
\hline \multicolumn{2}{|r|}{ WELDING REQUIREMENTS } & & $\begin{array}{r}\text { SECTION NO. } \\
8.0\end{array}$ & $\begin{array}{r}\text { PAGE NO. } \\
4\end{array}$ \\
\hline
\end{tabular}

\subsection{Radiographic Examination}

Radiographic examination shall be made in accordance with Section III of the ASME Code and ROT E-15-2NB-T, except that examination shall be made at the maximum sensitivity as established by penetrameter or standard comparisons.

Double viewing with separate images shall be taken where possible at $0^{\circ}, 60^{\circ}$ and $120^{\circ}$. Where separate images are not possible because of geometry, superimposed images are acceptable. Where $0^{\circ}, 60^{\circ}$ and $120^{\circ}$ angle shots are not possible because of geometry angle shots shall be taken at $0^{\circ}, 45^{\circ}$ and $90^{\circ}$, or as many of the three orientations $\left(0^{\circ}, 45^{\circ}\right.$ and $\left.90^{\circ}\right)$ as possible. Radiographic procedures shall include the direction of shots and whether separate or superimposed images will be obtained.

\subsection{Helium Leak Test}

Helium leak tests shall be performed in accordance with Article 10 of ASME Code, Section $V$. The following parts of Article 10 are deleted:

T1030 Gas and Bubble Formation Testing

T1040 Halogen Diode Detector Testing ("Sniffer Method")

T1050 Hel ium Mass Spectrometer Testing (Reverse Probe - "Sniffer Method")

The following additional requirement supplements the indicated part of Article 10.

T1072 Report. add:

A detailed report shall be made after testing has been completed and shall contain the followng information as a minimum:

1. Procedure designation and equipment used

2. Operator's name and date of test

3. Number and nature of leaks found. 


\begin{tabular}{|c|c|c|c|c|}
\hline $\begin{array}{l}\text { Hanford Engineering } \\
\text { Development Laboratory }\end{array}$ & 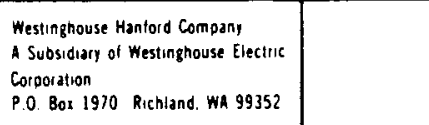 & $\begin{array}{c}\text { CORE TECHNOLOGY AND SAFETY } \\
\text { ENGINEERING TEST PLAN }\end{array}$ & $\begin{array}{r}\text { REVISION } \\
1\end{array}$ & DATE \\
\hline $\begin{array}{l}\text { TEST SERIES } \\
\text { HEDL, TRAN }\end{array}$ & SIENT TEST PROGRAM & SERIES TEST PLAN & \multicolumn{2}{|l|}{ APPROVED } \\
\hline \multicolumn{2}{|r|}{ WELDING REQUIREMENTS } & & $\begin{array}{r}\text { SECTION NO } \\
8.0\end{array}$ & $\begin{array}{r}\text { PAGE NO. } \\
5\end{array}$ \\
\hline
\end{tabular}

8.1.4 SPTL Outfitting and Final Assembly Welding (H-3-47129, $\mathrm{H}-3-47130$ and H-3-47131)

All outfitting and final assembly welding shall be in accordance with the drawings and the designated sections of RDT F6-2 and this document.

The clamp bails (Drawing No. R0202-0131) shall be GTAW welded in a clean area using either ER $\mathrm{Ni} \mathrm{CrFe-7}$ or ER $\mathrm{Ni} \mathrm{Cr}-3$ weld wire.

\subsubsection{Procedures and Qualifications}

Table 8.1.1 shows the weld qualification requirements for each SPTL outfitting and final assembly weld.

\subsection{Resistance Spot Welding}

Resistance welding procedures utilized on the SPTL loop fabrication shall employ a capacitor discharge resistance spot welding machine with a pressure operated discharge mechanism. Each type and size of RSW shall be predemonstrated and qualified on simulated samples of production hardware, including material thicknesses, composition and surface conditions, which must be welded in the loop fabrication.

After establishing optimum RSW parameters and machine settings, the SPTL weld procedure shall be prepared with the following information as a minimum:

Drawing and Procedure Number

Welding Machine (model - serial)

Electrical Capability

Pressure Application - Settings

Weld Parameters (electrode force in pounds, energy in watt seconds, pulse shape and duration, range switch settings)

Base Materials 
TABLE 8.I.I

OUTFIIIING AND FINAL ASSEMBLY WELD QUALIFICATION REQUIREMENTS

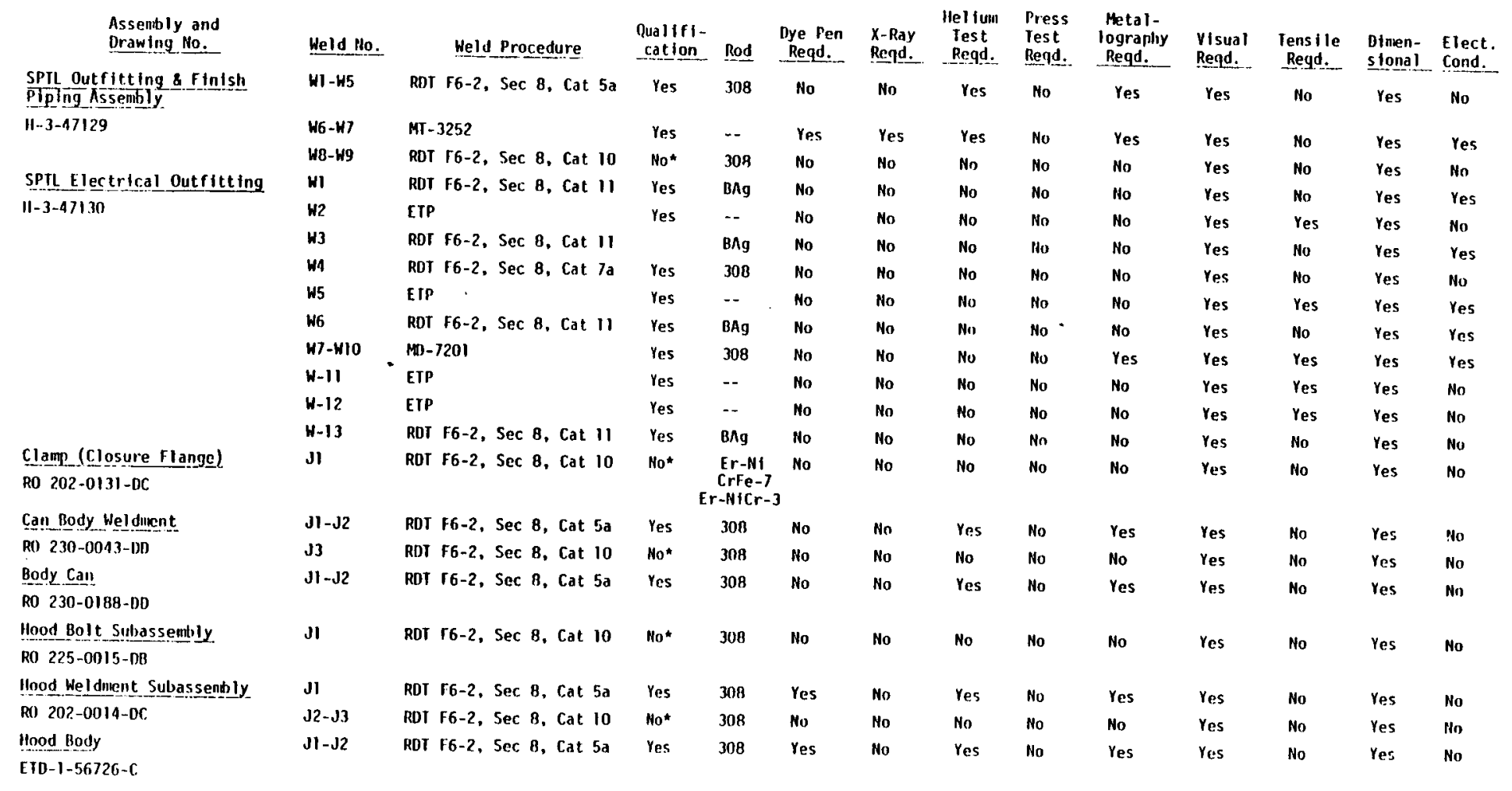

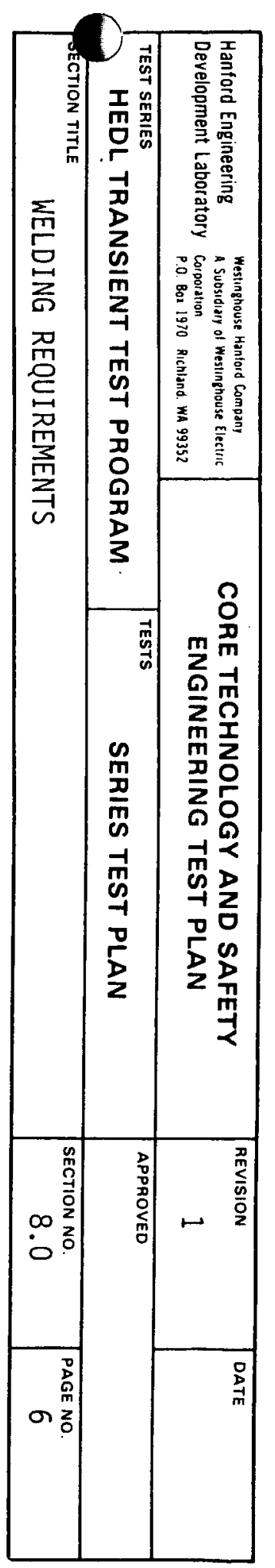


SINGLE PIN TEST LOOP ALIP ANO LOWER FLOWMETER FINAL ASSEMBLY Weld Qualification Requirements

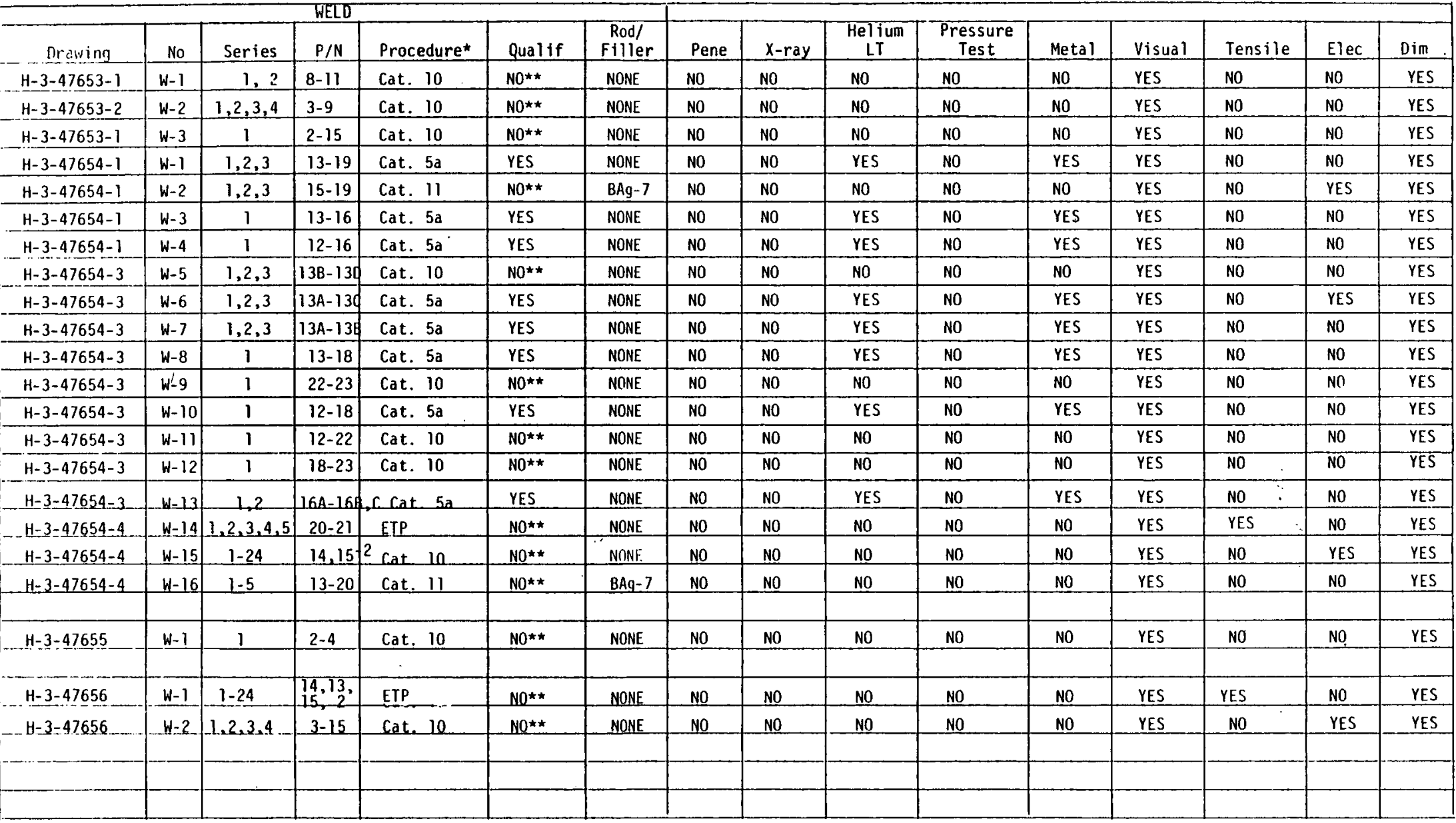

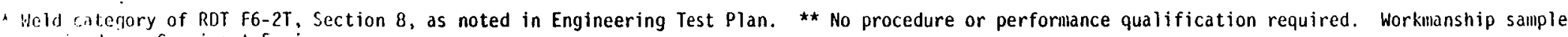
Eaprired per Cognizant Engineer.
Page 1 of 1

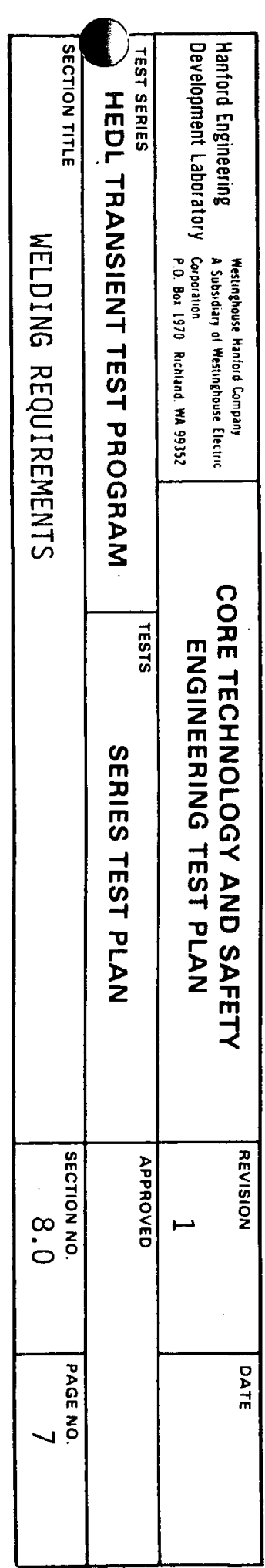




\begin{tabular}{|c|c|c|c|c|}
\hline $\begin{array}{l}\text { Hanford Engineering } \\
\text { Development Laboratory }\end{array}$ & 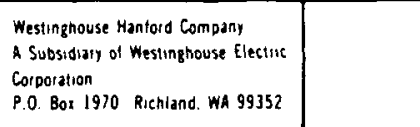 & $\begin{array}{c}\text { CORE TECHNOLOGY AND SAFETY } \\
\text { ENGINEERING TEST PLAN }\end{array}$ & $\begin{array}{r}\text { REVISION } \\
1\end{array}$ & DATE \\
\hline \multicolumn{2}{|c|}{$\begin{array}{l}\text { TEST SERIES } \\
\text { HEDL TRANSIENT TEST PROGRAM }\end{array}$} & SERIES TEST PLAN & \multicolumn{2}{|l|}{ APPROVED } \\
\hline \multicolumn{2}{|r|}{ WELDING REQUIREMENTS } & & $\begin{array}{r}\text { SECTION NO. } \\
8.0\end{array}$ & $\begin{array}{r}\text { PAGE NO. } \\
8\end{array}$ \\
\hline
\end{tabular}

Material Form

Material Gauge

Joint Design Sketch (showing weld spacing and overlap)

Welding Electrode Information

The RSW procedure shall be qualified by making three consecutive single welds which exhibit good quality and meet the following acceptance criteria:

Visual Examination - RSW spots shall exhibit a slight depression with a $r$ im which has a smooth radius when examined at ( $3 x$ to $5 x$ magnification). Welds which have any of the following defects are to be rejected.

- No deformation or excessive deformation (over $50 \%$ of material thickness)

- Expulsion - Excessive overheating - Pitting - Cracking Excessive Oxidation or Spalling.

Destructive Tests - Test Welds shall be peel tested to failure. A weld shall be judged acceptable if the peel test results in a hole in the peeled-off component that is at least the thickness of the component.

An alternate tensile test may be performed. If the tensile strength for each material combination is greater than the acceptance criterion established by the Fabrication Development welding engineer, the weld qualification is acceptable.

\subsubsection{Production Weld Acceptance Criteria}

All welds shall comply with the drawings and the requirements of RDT F6-2. As a minimum, all welds are to be visually and dimensionally examined. All resistance welds shall be visually examined and shall meet the requirements stated in 8.1.4.1.1.

Leak tight shall be a helium leak rate less than $1.0 \times 10^{-8} \mathrm{Scc} / \mathrm{sec}$ of helium unless otherwise specified on the drawings. 


\begin{tabular}{|c|c|c|c|c|}
\hline $\begin{array}{l}\text { Hanford Engineering } \\
\text { Development Laboratory }\end{array}$ & 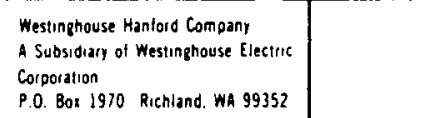 & $\begin{array}{c}\text { CORE TECHNOLOGY AND SAFETY } \\
\text { ENGINEERING TEST PLAN }\end{array}$ & $\begin{array}{r}\text { REVISION } \\
1\end{array}$ & DATE \\
\hline \multicolumn{2}{|c|}{$\begin{array}{l}\text { TEST SERIES } \\
\text { HEDL TRANSIENT TEST PROGRAM }\end{array}$} & SERIES TEST PLAN & \multicolumn{2}{|l|}{ APPROVED } \\
\hline \multicolumn{2}{|r|}{ WELDING REQUIREMENTS } & & $\begin{array}{r}\text { SECTION NO. } \\
8.0 \\
\end{array}$ & $\begin{array}{r}\text { PAGE NO. } \\
9\end{array}$ \\
\hline
\end{tabular}

\subsubsection{Annular Linear Induction Pump (ALIP) and Flow Sensor Welding}

Al1 components containing pressure boundary welds listed in Table 6.1 .1 shall be in accordance with the weld qualification described in paragraphs 8.1.2 and 8.1 .3 herein.

Table 8.1.2 shows the non-pressure boundary weld qualification requirements. A11 non-pressure boundary welds shall be made to Section 8 of RDT F6-2T and this document.

Paragraphs 8.1.4.1.1 and 8.1.4.2 apply to the ALIP and flowmeter non-pressure boundary welds.

Workmanship sample welds may be required to meet fabricator/cognizant engineer acceptance.

The following welds, al though not requiring qualification, will require a workmanship demonstration sample to include leak, visual, and metallography testing:

Orawing $\mathrm{H}-3-47654, \mathrm{~W}-9, \mathrm{~W}-11, \mathrm{~W}-12$

Drawing H-3-47655, W-1.

\subsection{TEST TRAIN WELDING REQUIREMENTS}

\subsubsection{Procedures}

All welding shall be in accordance with the drawings and the appropriate sections of the RDT Welding Standard RDT F6-2, "Welding of Reactor Core Components and Test Assemblies," and this test plan. Work instructions shall be prepared by the sections having responsibilities as indicated in this ETP. 


\begin{tabular}{|c|c|c|c|c|}
\hline $\begin{array}{l}\text { Hanford Engineering } \\
\text { Development Laboratory }\end{array}$ & $\begin{array}{l}\text { Westinghouse Hantord Company } \\
\text { A Substidiary of Westinghouse Electric } \\
\text { Corporation } \\
\text { P.O. Bos } 1970 \text { Richland. Wa } 99352\end{array}$ & $\begin{array}{c}\text { CORE TECHNOLOGY AND SAFETY } \\
\text { ENGINEERING TEST PLAN }\end{array}$ & $\begin{array}{r}\text { REVISION } \\
1\end{array}$ & DATE \\
\hline $\begin{array}{l}\text { TEST SERIES } \\
\text { HEDL TRAN }\end{array}$ & ISIENT TEST PROGRAM & SERIES TEST PLAN & \multicolumn{2}{|l|}{ APPROVED } \\
\hline \multicolumn{2}{|r|}{ WELDING REQUIREMENTS } & & $\begin{array}{c}\text { SECTION NO. } \\
8.0 \\
\end{array}$ & $\begin{array}{r}\text { PAGE NO } \\
10\end{array}$ \\
\hline
\end{tabular}

Brazing sequence shall be specified in the assembly work instructions. Table 8.2.1 shows the weld qualification requirements for each test train weld. The tensile test load requirement for the bellows-to-tube welds, Drawing $H-3-47879$, Welds $W-25$ and $W-26$, is a force greater than 45 pounds.

\subsubsection{Attachment of Thermocouple Lead Wires and Thermocouple Hold Down Straps}

Attachment welds shall be made with a capacitor discharge resistance spot welding machine using a force triggered hand probe. A welding procedure shall be prepared and qualified for each application. Materials of job thickness, composition and surface condition shall be used in performing the tests. The welding parameters shall be selected by performing prequalification tests. After the proper machine settings have been determined, the following data shall be recorded on the Welding Procedure sheet: job title, drawing number, welding machine (name, model, S/N), electrical rating, type of pressure application, base materials, material form, material thickness, joint design sketch (showing weld spacing and overlap), welding electrode information (alloy class, shank and face diameter, shape of face and distance between welding electrode and ground electrode), welding machine parameters (electrode force in pounds, energy in watt-seconds, pulse shape and duration, and range switch settings) welding cable length, welding operators name, data qualification welds made, and weld joint number.

The welding procedure shall be qualified by making three consecutive single welds. All three welds shall meet the following acceptance criteria.

- Visual Examination - The surface of the parts welded shall reveal a slight depression with a rim which is radially smooth. The following conditions shall be cause for rejection: no deformation, excessive deformation (over $50 \%$ of material thickness), expulsion, evidence of excessive overheating such as surface melting, pitting, cracking, and accumulation of flaking, spalling or wrinkled black and gray oxidation, and deposition of electrode material on surface of welded parts. Visual examination shall be performed at $3 X$ to $5 X$ magnification. 


\begin{tabular}{|c|c|c|c|c|}
\hline $\begin{array}{l}\text { Hanford Engineering } \\
\text { Development Laboratory }\end{array}$ & 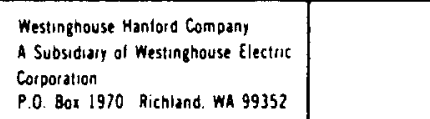 & $\begin{array}{c}\text { CORE TECHNOLOGY AND SAFETY } \\
\text { ENGINEERING TEST PLAN }\end{array}$ & $\begin{array}{r}\text { REVISION } \\
1 \\
1\end{array}$ & DATE \\
\hline $\begin{array}{l}\text { TEST SEAIES } \\
\text { HEDL TRAR }\end{array}$ & ISIENT TEST PROGRAM & SERIES TEST PLAN & \multicolumn{2}{|l|}{ APPROVED } \\
\hline SECTION TITLE & NELDING REQU IREMENTS & & $\begin{array}{c}\text { SECTION NO. } \\
8.0\end{array}$ & $\begin{array}{r}\text { PAgE NO. } \\
11\end{array}$ \\
\hline
\end{tabular}

- Destructive Tests - The test welds shall be tensile-shear tested . to failure. The tensile-shear strength for each weld shall not be less than the strength shown on the drawing welding symbols.

\subsubsection{Acceptance Criteria}

All test train welds shall comply with the drawings and the requirements of RDT F6-2 with the following exceptions:

- Visual Exaination - Visual inspections of Welds $W-40$ and $W-41$ of $\mathrm{H}-3-47103$, and $W e l d s \mathrm{~W}-25$ and $W-26$ of $H-3-47879$ shall be done at not less than $10 x$ magnification.

- A11 brazes sha11 meet the requirements of RDT F6-2, Section 8 and RDT F6-14, "Brazing Fabrication Requirements," except that braze alloy shall be ASTM B-260 or SFA-5.8, AWS Classification BNi-8. In addition, the exit weldment assembly braze and welds shall be pressure tested as specified in Section 10.2.10.

- All instrumentation resistance welds shall be visually examined and shall meet the requirement stated in 8.2.1.1. 
TABLE 8.2.1

WELD QUAL IFICATION REQUIREMENTS FOR SINGLE PIN IEST TRAIN

Drawing H-3-47103

\begin{tabular}{|c|c|c|c|c|c|c|c|c|c|c|c|c|c|}
\hline \multicolumn{5}{|c|}{ WELD } & \multirow{2}{*}{$\begin{array}{c}\text { Dye Pen } \\
\text { Req. }\end{array}$} & \multirow{2}{*}{$\begin{array}{c}\text { X-Ray } \\
\text { Req. }\end{array}$} & \multirow{2}{*}{$\begin{array}{l}\text { Helium } \\
\text { Leak Test } \\
\text { Req. }\end{array}$} & \multirow{2}{*}{$\begin{array}{c}\text { Pressure } \\
\text { Test } \\
\text { Reg. }\end{array}$} & \multirow{2}{*}{$\begin{array}{l}\text { Metal- } \\
\text { lography } \\
\text { Req. }\end{array}$} & \multirow{2}{*}{$\begin{array}{l}\text { Visual } \\
\text { Req. }\end{array}$} & \multirow{2}{*}{$\begin{array}{c}\text { Tensile } \\
\text { Reo. }\end{array}$} & \multirow{2}{*}{$\begin{array}{l}\text { Elect. } \\
\text { Cond. } \\
\text { Req. }\end{array}$} & \multirow{2}{*}{$\begin{array}{l}\text { Dimen. } \\
\text { Req. }\end{array}$} \\
\hline No. & Part No. & Procedure & Qualif. & Rod & & & & & & & & & \\
\hline W-1 & $9 A / 9 B$ & MT-1-14, Cat 4 * & Yes & 308 & Yes & Yes & Yes & No & Yes & Yes & No & No & Yes \\
\hline W-2 & $39 G / 9 B$ & MT-4-1, Cat 11* & Yes & $\begin{array}{l}\text { B } \\
\text { B-260 } \\
\text { BNi8 }\end{array}$ & No & No & Yes & No & Yes & Yes & No & Yes & Yes \\
\hline$W-3$ & $39 F / 9 B$ & & & & & & & & & & & & \\
\hline$W-4$ & $39 E / 9 B$ & & & & & & & & & & & & \\
\hline$W-5$ & $39 C / 9 B$ & & & & & & & & & & & & \\
\hline$H-6$ & $39 A / 9 B$ & & & & & & & & & & & & \\
\hline$W-7$ & $52 / 9 B$ & & & & & & & & & & & & \\
\hline$W-8$ & $40 / 9 B$ & & & & & & & & & & & & \\
\hline$W-9$ & $390 / 9 B$ & & & & & & & & & & & & \\
\hline$W-10$ & $39 B / 9 B$ & $\downarrow$ & $\checkmark$ & 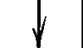 & 1 & $\gamma$ & $V$ & . & $\downarrow$ & & $\psi$ & $\downarrow$ & \\
\hline W-11 & $8 A / 8 B$ & ROT F6-2T Sec 8, Cát 10 & $\mathrm{No}^{\star \star \star}$ & -- & No & No & No & No & Ho & Yes & No & No & Yes \\
\hline W- 12 & $8 \mathrm{~B} / 8 \mathrm{C}$ & & & & 1 & & & 1 & 1 & & $\mid$ & $\mid$ & 1 \\
\hline$w-13$ & $8 \mathrm{C} / \mathrm{ED}$ & & & & & & & & & & & & \\
\hline$W-14$ & $80 / 8 \mathrm{E}$ & & & & & & & & & & & & \\
\hline$W-15$ & $8 \mathrm{E} / 8 \mathrm{~F}$ & & & & & & & & & & & & \\
\hline$W-16$ & $8 F / 8 G$ & $\downarrow$ & $\psi$ & $\psi$ & $y$ & & $\downarrow$ & 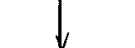 & & $v$ & & 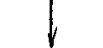 & 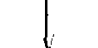 \\
\hline$W-17$ & $11 / 13$ & MT-2-5, Cat 7* & Yes & $-\cdots$ & Yes & Yes & No & No & Yes & Yes & No & No & Yes \\
\hline$H-18$ & $13 / 14$ & MT-1-13, Cat 7* & Yes & 308 & Yes & No & No & No & Yes & Yes & No & No & Yes \\
\hline$W-19$ & $15 / 5 A$ & ROT F6-2T Sec 8, Cat 10 & $\mathrm{No}^{\star \star *}$ & 308 & No & Ho & No & No & No & Yes & No & No & Yes \\
\hline W-20 & $15 / 5 A$ & & & & & & & & & & & & \\
\hline$W-21$ & $23 / 15$ & & & & & & & & & & & & \\
\hline$W-22$ & $23 / 15$ & & & & & & & & & & & & \\
\hline$W-23 A$ & $15 / 5 A$ & & & & & & & & & & & & \\
\hline$W-23 B$ & $15 / 5 A$ & $\checkmark$ & & v & $\downarrow$ & & & & r & & & r & 1 \\
\hline
\end{tabular}

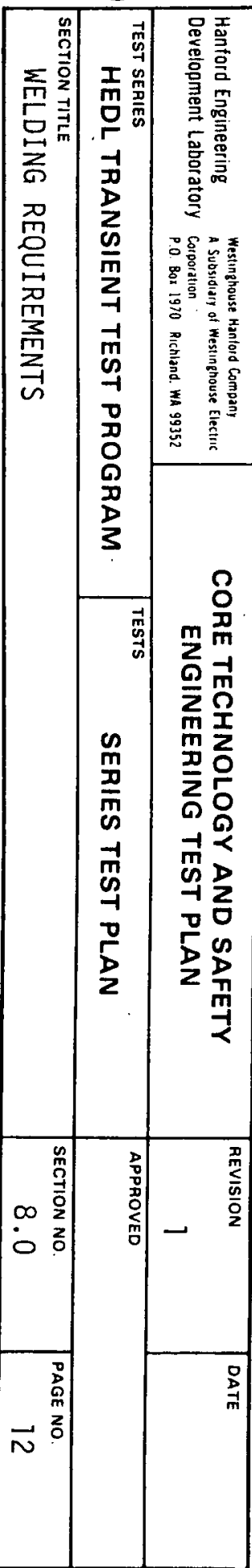

* WELD Category of RDT F6-2T, Section 8

** No procedure qualification required. Performance qualification required per RDT-F6-2T. 
Table 8.2.1 (Con't)

WELD QUALIFICATION REQUIREMENTS FOR SINGLE PIN TEST TRAIN

Drawing $\mathrm{H}-3-47103$ (Con't)

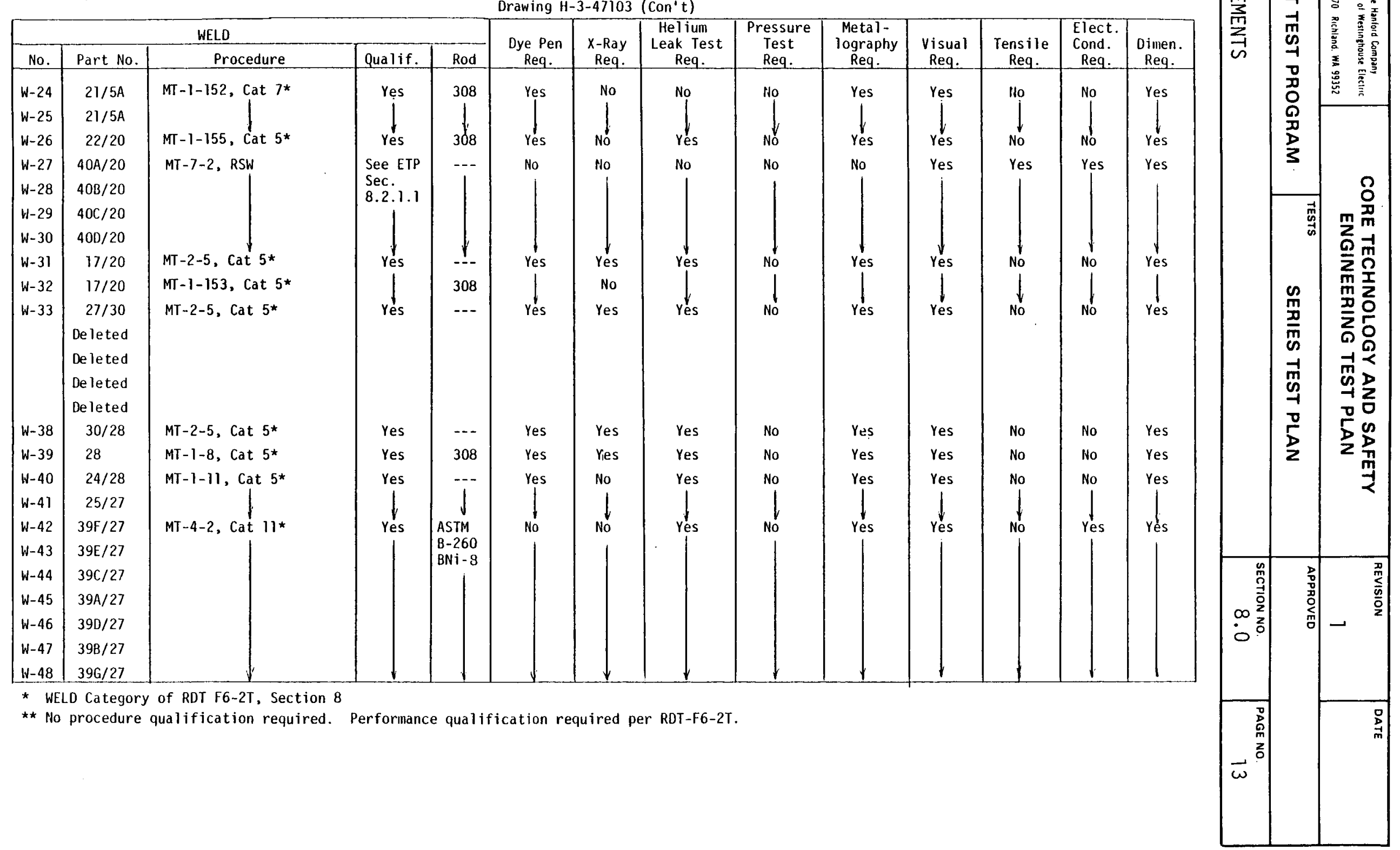


Table 8.2.1 ( $\left.\operatorname{Con}^{\prime} t\right)$

WELD QUALIFICATION REQUIREMENTS FOR SINGLE PIN TEST TRAIN

Drawing $\mathrm{H}-3-47103$ ( $\mathrm{Con}^{\circ} \mathrm{t}$ )

\begin{tabular}{|c|c|c|c|c|c|c|c|c|c|c|c|c|c|}
\hline \multicolumn{5}{|c|}{ WELD } & \multirow[b]{2}{*}{$\begin{array}{c}\text { Dye Pen } \\
\text { Req. }\end{array}$} & \multirow[b]{2}{*}{$\begin{array}{c}\text { X-Ray } \\
\text { Req. }\end{array}$} & \multirow{2}{*}{$\begin{array}{c}\text { Helium } \\
\text { Leak Test } \\
\text { Req. }\end{array}$} & \multirow{2}{*}{$\begin{array}{c}\text { Pressure } \\
\text { Test } \\
\text { Req. }\end{array}$} & \multirow{2}{*}{$\begin{array}{l}\text { Metal- } \\
\text { lography } \\
\text { Req. }\end{array}$} & \multirow[b]{2}{*}{$\begin{array}{c}\text { Visual } \\
\text { Req. }\end{array}$} & \multirow[b]{2}{*}{$\begin{array}{c}\text { Tensile } \\
\text { Req. }\end{array}$} & \multirow{2}{*}{$\begin{array}{l}\text { Elect. } \\
\text { Cond. } \\
\text { Reg. }\end{array}$} & \multirow[b]{2}{*}{$\begin{array}{l}\text { Dimen. } \\
\text { Reg. }\end{array}$} \\
\hline No. & Part Ho. & Procedure & Qualif. & Rod & & & & & & & & & \\
\hline$W-49$ & $19 / 10$ & RDT F6-2T Sec 8, Cat 10 & No & 308 & Ho & No & No & No & No & Yes & No & No & Yes \\
\hline$W-50$ & $33 A / 33 B$ & MT-1-150, Cat 7* & Yes & 308 & Yes & No & No & No & Yes & Yes & No & No & Yes \\
\hline$W-51$ & $33 B / 33$ & & & & & & & & & & & & \\
\hline$W-52$ & $33 C / 33$ & & & & & & & & & & & & \\
\hline W-53 & $35 / 37$ & MT-1-155, Cat 10* & No $\star \star \star$ & - & No & No & No & No & No & Yes & No & No & Yes \\
\hline W-54 & $37 / 32$ & MT-2-5, Cat $7^{\star}$ & Yes & --- & Yes & Yes & No & No & Yes & Yes & No & No & Yes \\
\hline$H-55$ & $32 / 34$ & & & & & & & & & & & & \\
\hline$W-56$ & $7 / 4$ & & & & & & & & & & & & \\
\hline$W-57$ & $16 / 7$ & & & & & & & & & & & & \\
\hline$W-58$ & $5 / 6$ & & & & & & & & & & & & \\
\hline$W-59^{\circ}$ & $2 / 3$ & & V & & $\downarrow$ & 1 & 1 & $\downarrow$ & $y$ & & $\Downarrow$ & & \\
\hline$W-60$ & $39 A / 25$ & MT-7-2, RSW & See ETP & -1 & No & No & No & No & No & Yes & Yes & Yes & Yes \\
\hline$W-61$ & $39 B / 25$ & & $\begin{array}{l}\text { Sec. } \\
8.2 .1 .1\end{array}$ & & & & & & & & & & \\
\hline$W-62$ & $39 \mathrm{C} / 25$ & & & & & & & & & & & & \\
\hline$W-63$ & $390 / 25$ & & & & & & & & & & & & \\
\hline$W-64$ & $39 E / 25$ & & & & & & & & & & & & \\
\hline$W-65$ & $39 F / 25$ & & & & & & & & & & & & \\
\hline$W-66$ & $39 G / 25$ & & & $\sqrt{ }$ & $y$ & & & & & & & $l$ & \\
\hline$W-67$ & 20 & MT-1-8, Cat 5* & Yes & 308 & Yes & Yes & Yes & No & Yes & Yes & No & No & Yes \\
\hline$W-68$ & $40 / 22$ & MT-4-2, Cat 11 * & Yes & $\begin{array}{l}\text { ASTM } \\
B-260 \\
B N i-8\end{array}$ & No & No & Yes & No & Yes & Yes & No & Yes & Yes \\
\hline$W-69$ & $6 / 16$ & MT-2-5, Cat 7 * & Yes & --- & Yes & Yes & No & No & Yes & Yes & No & No & Yes \\
\hline
\end{tabular}

* WELD Category or RDT F6-2T, Section 8 .

** No procedure qualification required. Perfornance qualification required per RDT-F6-2T. 
TABLE 8.2 .1 ( Con't $t$ )

WELD QUAL IFICATION REQUIREMENTS FOR SINGLE PIN TEST TRAIN

Adiabatic Region Flow Tube Assembly - Drawing H-3-47879

\begin{tabular}{|c|c|c|c|c|c|c|c|c|c|c|c|c|c|}
\hline \multicolumn{5}{|c|}{ WELD } & \multirow{2}{*}{$\begin{array}{c}\text { Dye Pen } \\
\text { Req. }\end{array}$} & \multirow{2}{*}{$\begin{array}{c}\text { X-Ray } \\
\text { Req. }\end{array}$} & \multirow{2}{*}{$\begin{array}{l}\text { Helium } \\
\text { Leak Test } \\
\text { Req. }\end{array}$} & \multirow{2}{*}{$\begin{array}{c}\text { Pressure } \\
\text { Test } \\
\text { Req. } \\
\end{array}$} & \multirow{2}{*}{$\begin{array}{l}\text { Metal- } \\
\text { lography } \\
\text { Req. }\end{array}$} & \multirow{2}{*}{$\begin{array}{c}\text { Visual } \\
\text { Reg. }\end{array}$} & \multirow{2}{*}{$\begin{array}{c}\text { Tensile } \\
\text { Req. }\end{array}$} & \multirow{2}{*}{$\begin{array}{l}\text { Elect. } \\
\text { Cond. } \\
\text { Req. }\end{array}$} & \multirow[b]{2}{*}{$\begin{array}{c}\text { Dimen. } \\
\text { Reg. }\end{array}$} \\
\hline No. & Part No. & Procedure & Qualif. & Rod & & & & & & & & & \\
\hline$W-1$ & $2 / 3$ & MT-2-172, Cat. 5* & Yes & - & Yes & No & Yes & No & Yes & Yes & No & No & Yes \\
\hline$W-2$ & $3 / 7$ & & & 1 & 1 & 1 & 1 & & 1 & 1 & 1 & & \\
\hline$w-3$ & $7 / 3$ & & & & & & & & & & & & \\
\hline$w-4$ & $3 / 8$ & & & & & & & & & & & & \\
\hline$w-5$ & $8 / 3$ & & & & & & & & & & & & \\
\hline$W-6$ & $3 / 9$ & & & & & & & & & & & & \\
\hline$W-7$ & $9 / 3$ & & & & & & & & & & & & \\
\hline$W-8$ & $3 / 10$ & & & & & & & & & & & & \\
\hline W-9 & $10 / 3$ & & & & & & & & & & & & \\
\hline$W-10$ & $3 / 11$ & & & & & & & & & & & & \\
\hline$w-11$ & $11 / 3$ & & & & & & & & & & & & \\
\hline$w-12$ & $3 / 12$ & & & & & & & & & & & & \\
\hline$w-13$ & $12 / 3$ & & & & & & & & & & & & \\
\hline$W-14$ & $3 / 13$ & & & & & & & & & & & & \\
\hline$W-15$ & $13 / 3$ & & & & & & & & & & & & \\
\hline$W-16$ & $3 / 14$ & & & & & & & & & * & & & \\
\hline$W-17$ & $14 / 3$ & & & & & & & & & & & & \\
\hline$w-18$ & $3 / 15$ & & & & & & & & & & & & \\
\hline$W-19$ & $15 / 3$ & & & & & & & & & & & & \\
\hline$W-20$ & $3 / 16$ & & & & & & & & & & & & \\
\hline$W-21$ & $16 / 3$ & & & & & & & & & & & & \\
\hline$W-22$ & $3 / 4$ & & $\downarrow$ & $\downarrow$ & $\downarrow$ & $\downarrow$ & $\downarrow$ & 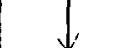 & $\downarrow$ & $\downarrow$ & $\downarrow$ & $\sqrt{1}$ & $\sqrt{1}$ \\
\hline$W-23$ & $6 / 10$ & RDT F6-2T, Sec 8, Cat 10 & No & 308 & No & No & No & No & No & Yes & No & No & Yes \\
\hline$W-24$ & $6 / 14$ & & $\downarrow$ & $\downarrow$ & $\downarrow$ & $\downarrow$ & $\downarrow$ & $\downarrow$ & $\downarrow$ & $\downarrow$ & $\downarrow$ & $\downarrow$ & $\downarrow$ \\
\hline$W-25$ & $4 / 5$ & MT $-2-4$, Cat 5 * & Yes & 308 & Yes & No & Yes & No & Yes & Yes & Yes & No & Yes \\
\hline$W-26$ & $5 / 17$ & & $\downarrow$ & $\downarrow$ & $\downarrow$ & $\downarrow$ & $\downarrow$ & $\downarrow$ & $\downarrow$ & $\downarrow$ & & $\downarrow$ & $\downarrow$ \\
\hline
\end{tabular}

* Weld Category of ROT F6-2T, Section 8

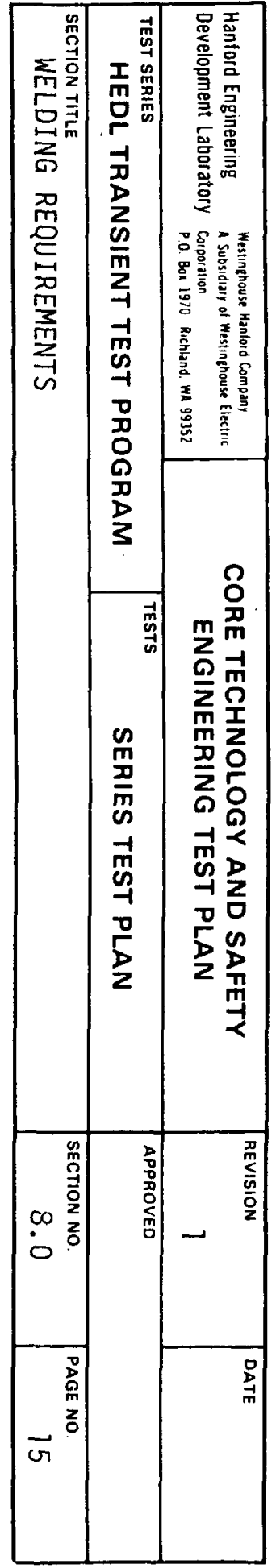


TABLE 8.2.1 (Con't)

WELO QUALIFICATION REQUIREMENTS FOR SINGLE PIN TEST TRAIN

Inlet Plenum Flow Tube Assembly - Drawing H-3-47886

\begin{tabular}{|c|c|c|c|c|c|c|c|c|c|c|c|c|c|}
\hline \multicolumn{5}{|c|}{ WELLD } & \multirow{2}{*}{$\begin{array}{c}\text { Dye Pen } \\
\text { Req. }\end{array}$} & \multirow{2}{*}{$\begin{array}{c}x-\text { Ray } \\
\text { Req. }\end{array}$} & \multirow{2}{*}{$\begin{array}{l}\text { HeTium } \\
\text { Leak Test } \\
\text { Reg. }\end{array}$} & \multirow{2}{*}{$\begin{array}{c}\text { Pressure } \\
\text { Test } \\
\text { Reg. } \\
\end{array}$} & \multirow{2}{*}{$\begin{array}{c}\text { Metal- } \\
\text { lography } \\
\text { Req. }\end{array}$} & \multirow[b]{2}{*}{$\begin{array}{c}\text { Visual } \\
\text { Reg. }\end{array}$} & \multirow{2}{*}{$\begin{array}{c}\text { Tensile } \\
\text { Req. }\end{array}$} & \multirow{2}{*}{$\begin{array}{l}\text { Elect. } \\
\text { Cond. } \\
\text { Req. }\end{array}$} & \multirow{2}{*}{$\begin{array}{l}\text { Dimen. } \\
\text { Reg. }\end{array}$} \\
\hline No. & Part No. & Procedure & Qual if. & Rod & & & & & & & & & \\
\hline W-I & $2 / 3$ & MT-2-172 & Yes & - & No & No & No & No & Yes & Yes & No & No & Yes \\
\hline$w-2$ & $3 / 4$ & & & $\mid$ & & ] & & 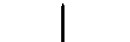 & 1 & & 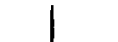 & 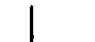 & \\
\hline$w-3$ & $4 / 3$ & & & & & & & & & & & & \\
\hline$W-4$ & $3 / 5$ & & & & & & & & & & & & \\
\hline$W-5$ & $5 / 3$ & & & & & & & & & & & & \\
\hline W-6 & $3 / 6$ & & & & & & & & & & & & \\
\hline W-7 & $6 / 7$ & $\checkmark$ & $\Downarrow$ & $\downarrow$ & $\downarrow$ & $\downarrow$ & $\Downarrow$ & $\Downarrow$ & $\vee$ & $\vee$ & $\downarrow$ & $\downarrow$ & $\downarrow$ \\
\hline & & & & & & & & & & & & & \\
\hline & & & & & & & & & & & & & \\
\hline & & & & & & & & & & & & & \\
\hline & & & & & & & & & & & & & \\
\hline & & & & & & & & & & & & & \\
\hline & & & & & & & & & & & & & \\
\hline & & & & & & & & & & & & & \\
\hline & & & & & & & & & & & & & \\
\hline & & & & & & & & & & & & & \\
\hline
\end{tabular}

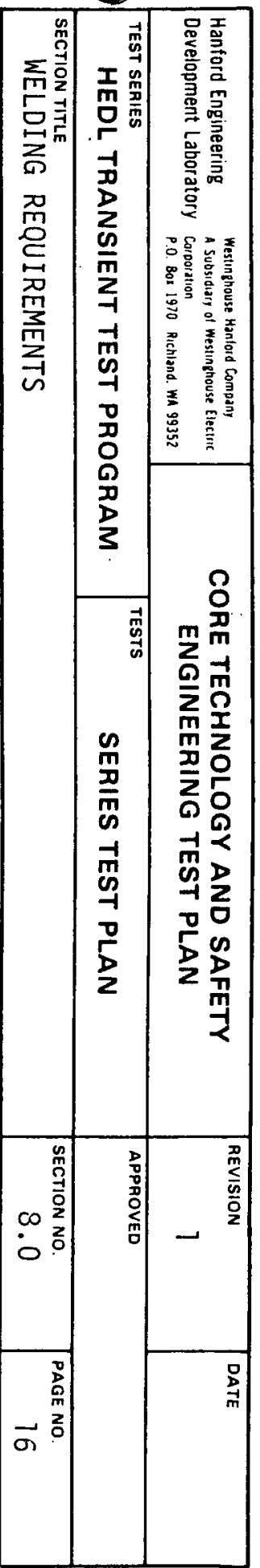




\begin{tabular}{|c|c|c|c|c|}
\hline $\begin{array}{l}\text { Hanford Engineering } \\
\text { Development Laboratory }\end{array}$ & 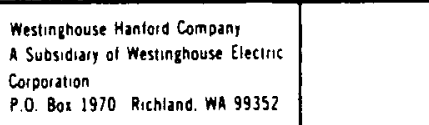 & $\begin{array}{c}\text { CORE TECHNOLOGY AND SAFETY } \\
\text { ENGINEERING TEST PLAN }\end{array}$ & $\begin{array}{r}\text { REVISION } \\
1\end{array}$ & DATE \\
\hline $\begin{array}{l}\text { TEST SERIES } \\
\text { HEDL TRANS }\end{array}$ & SIENT TEST PROGRAM & SERIES TEST PLAN & \multicolumn{2}{|l|}{ APPROVED } \\
\hline CLEANING REQUIREMENTS & EANING REQUIREMENTS & & $\begin{array}{r}\text { SECTION NO } \\
9.0\end{array}$ & $\begin{array}{r}\text { PAGE NO } \\
1\end{array}$ \\
\hline
\end{tabular}

- 9.0 CLEANING REQUIREMENTS

During fabrication, storage, welding and assembly operations, etc., precautions are to be taken to assure the cleanliness of the final test articles.

\subsection{LOOP CLEANING REQUIREMENTS}

The fabrication of the loop subassembly shall be conducted to facilitate cleaning and inspection for cleanliness and to minimize contamination during fabrication and assembly. Surfaces shall be cleaned in accordance with ROT F5-1 and shall be maintained in a clean condition throughout all processes. Written cleaning procedures shall be prepared in accordance with RDT F5-1. Once fabrication of the subassembly has proceeded such that visual inspection of all internal surfaces for cleanliness is not possible, the fabricator shall seal all openings of the subassembly in accordance with F7-2 to prevent contamination. Except as required during the normal course of fabrication, the seals shall not be broken. For these cases, appropriate precautions, including use of clean room, clean areas, glove boxes, etc., shall be employed to preclude entry of foreign material into the subassembly during the fabrication operations. If the seal should be lost and there is not assurance that foreign matter has not entered the subassembiy, then the subassembly shall be recleaned to meet the requirements of RDT F5-1. As a minimum, the following items shall be addressed in the appropriate procedures:

9.1.1 All work areas or equipment which will come into contact with any component of the test article shall be cleaned prior to being put into service or covered with polyethylene sheeting. Cleaning shall consist of wiping with clean unbleached cotton swabs or cloth using ethyl alcohol.

9.1.2 Individual stainless metal components, but not assemblies, may be acid cleaned. Acid cleaning procedures are to meet the requirements of Section 4.7 of RDT F5-1. Final water rinsing can be performed using grade $B$ water. 


\begin{tabular}{|c|c|c|c|c|}
\hline $\begin{array}{l}\text { Hanford Engineering } \\
\text { Development Laboratory }\end{array}$ & 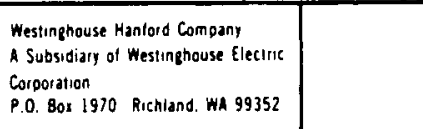 & $\begin{array}{c}\text { CORE TECHNOLOGY AND SAFETY } \\
\text { ENGINEERING TEST PLAN }\end{array}$ & $\begin{array}{r}\text { AEVISION } \\
1\end{array}$ & DATE \\
\hline $\begin{array}{l}\text { TEST SERIES } \\
\text { HEDL TRAN }\end{array}$ & SIENT TEST PROGRAM & SERIES TEST PLAN & \multicolumn{2}{|l|}{ APPROVED } \\
\hline \multicolumn{2}{|r|}{ CLEANING REQUIREMENTS } & & $\begin{array}{r}\text { SECTION NO } \\
9.0\end{array}$ & $\begin{array}{r}\text { PAGE NO. } \\
2\end{array}$ \\
\hline
\end{tabular}

Nickel-chromium-iron alloys (Inconel $\times 750$ ) shall not be alkaline or acid cleaned. Care shall be taken during heat treatment to prevent black oxide coatings. Temper films are acceptable.

9.1.3 Prior to cleaning, the open circumferential crevice between the top plate and closure tube opposite the fillet weld may be sealed with RTV-109 silicone sealant (or equivalent) to prevent cleaning solution from entering. This sealant, if used, shall be removed following cleaning and prior to final rinse.

9.1.4 Cleaned components shall be free of foreign materials when visually examined at $1 X$ magnification. White cloth patches rubbed over the surfaces which exhibit lubricants, metallic flakes, carbon or any other particles shall be cause for rejection.

9.1.5 Final cleaning of the test article components and assembly shall consist of wiping with clean unbleached cotton swabs or cloth using ethyl alcohol.

9.1.6 Cutting fluid content requirements of Section 7.0 shall be addressed in the fabrication instructions.

9.1.7 Assembly shall be conducted in a controlled work area.

9.1.8 All test article components are classified as coolant or critical surface.

9.1.9 After cleaning, each component is to be handled with lint-free gloves and stored in clean polyethylene covering or containers.

9.1.10 New stainless steel brushes shall be used to remove adherent scale.

9.1.11 Black oxide coatings are not acceptable surfaces. 


\begin{tabular}{|c|c|c|c|c|}
\hline $\begin{array}{l}\text { Hanford Engineering } \\
\text { Development Laboratory }\end{array}$ & 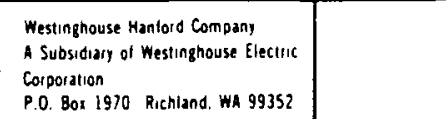 & $\begin{array}{c}\text { CORE TECHNOLOGY AND SAFETY } \\
\text { ENGINEERING TEST PLAN }\end{array}$ & $\begin{array}{r}\text { REVISION } \\
1 \\
1\end{array}$ & DATE \\
\hline TEST SERIES & VSIENT TEST PROGRAM & SERIES TEST PLAN & \multicolumn{2}{|l|}{ APPROVED } \\
\hline SECTION TITLE & CLEANING REQU IREMENTS & & $\begin{array}{c}\text { SECTION NO. } \\
9.0\end{array}$ & $\begin{array}{r}\text { PAGE NO } \\
3\end{array}$ \\
\hline
\end{tabular}

9.1.12 Austenitic stainless steel, which has become sensitized during operations such as heat treating, welding, or forming, shall be protected against corrosion and moisture during all subsequent manufacturing and storage operations.

9.1.13 In the event a situation with respect to cleaning or cleanliness should arise which is not covered in the approved cleaning procedures, it is to be brought to the attention of Transient Testing for resolution.

\subsubsection{ALIP and Flow Sensor Cleaning Requirements}

Sections 9.1 - 9.1.13 are applicable to SST components of the ALIP and flow sensors, with the exception of the laminations and coil subassemblies. Coil and lamination subassemblies will require special cleaning.

The coil wire shall be cut to approximate length (for the dual-coil subassembly) prior to cleaning. The prepared length shall be placed in a 20-25\% Nitric Acid solution, room temperature, for approximately 25 seconds, removed, sprayed with water, and dried. The wire must be used within 20 minutes or re-cleaning will be required.

The laminations must be free of al.l grease and dirt. If cleaning is required, an alcohol solution shall be used to wipe clean both surfaces of each lamination.

Once final assembly of the Calibration Test Article is complete, handling without lint free gloves, etc. is acceptable.

\subsection{TEST TRAIN CLEANING REQUIREMENTS}

The assembly of the test train components shall be conducted in a manner to facilitate cleaning, inspection for cleanliness, and to minimize contamination during installation and in the completed system or assembly. Surfaces 


\begin{tabular}{|c|c|c|c|c|}
\hline $\begin{array}{l}\text { Hanford Engineering } \\
\text { Development Laboratory }\end{array}$ & 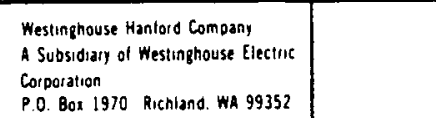 & $\begin{array}{c}\text { CORE TECHNOLOGY AND SAFETY } \\
\text { ENGINEERING TEST PLAN }\end{array}$ & $\begin{array}{r}\text { REVISION } \\
1\end{array}$ & DATE \\
\hline $\begin{array}{l}\text { TEST SERIES } \\
\text { HEDL TRAN }\end{array}$ & USIENT TEST PROGRAM & SERIES TEST PLAN & \multicolumn{2}{|l|}{ APPROVED } \\
\hline \multicolumn{3}{|c|}{ CLEANING REQUIREMENTS } & $\begin{array}{r}\text { SECTION NO } \\
9.0\end{array}$ & $\begin{array}{r}\text { PAGE NO. } \\
4\end{array}$ \\
\hline
\end{tabular}

shall be cleaned in accordance with RDT F5-1 and shall be maintained in a clean condition throughout all processes. Written cleaning procedures are to be prepared in accordance with RDT F5-1.

\subsection{IN-CELL WORK CLEANING REQUIREMENTS}

Care should be taken at all times to avoid particle contamination of the loop's sodium.

Presented here are the minimum requirements which are sufficient to provide the necessary cleanliness for the test apparatus.

9.3.1 All work areas or equipment which will come into contact with test train or fuel elements shall be cleaned prior to being put into service. cleaning shall consist of wiping with clean unbleached cotton swabs using ethyl alcohol.

\subsubsection{The use of water shall be minimized.}

9.3.3 No oxidizing agents such as nitric acid or halide environments shall come in contact with the test apparatus at any time. The components shall not be acid cleaned.

9.3.4 HFEF will receive the test train sealed in polyethylene, and the covering shall be opened prior to the loading of the fuel pin into the test train.

9.3.5 The fuel pins shall be wiped with clean unbleached cotton swabs using ethyl alcohol just prior to loading in the test train. The fuel pins are to be left in their shipping containers until just prior to loading in the test train. 


\begin{tabular}{|c|c|c|c|c|}
\hline $\begin{array}{l}\text { Hanford Engineering } \\
\text { Development Laboratory }\end{array}$ & 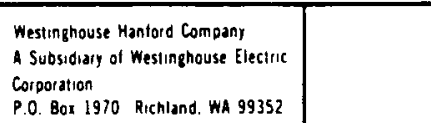 & $\begin{array}{c}\text { CORE TECHNOLOGY AND SAFETY } \\
\text { ENGINEERING TEST PLAN }\end{array}$ & $\begin{array}{r}\text { REVISION } \\
1\end{array}$ & DATE \\
\hline \multicolumn{2}{|c|}{$\begin{array}{l}\text { TEST SERIES } \\
\text { HEDL TRANSIENT TEST PROGRAM }\end{array}$} & SERIES TEST PLAN & \multicolumn{2}{|l|}{ APPROVED } \\
\hline \multicolumn{3}{|c|}{ CIFANING RFOUIRFMFNTS } & $\begin{array}{r}\text { SECTION NO } \\
9.0\end{array}$ & $\begin{array}{r}\text { PAGE NO. } \\
5\end{array}$ \\
\hline
\end{tabular}

9.3.6 Just prior to loading into the loop, the test train assembly shall be wiped with clean unbleached cotton swabs using ethyl alcohol. The test train assembly shall be protected as best as possible from general shop atmosphere. For any prolonged period of inactivity (more than $4 \mathrm{hrs}$ ), the test train assembly shall be sealed or covered with new polyethylene sheeting and masking tape. The masking tape shall not contact the cleaned component.

9.3.7 Materials which contain as major (>30\%) elements lead, sulfur, zinc, cadmium or other low melting point metals shall not be placed in contact with the test train and fuel pins. Aluminum shall not be allowed to come into contact with the pins after they have been removed from the shipping container and cleaned at HFEF.

9.3.8 Care shall be taken to avoid lodging or the accidental loss of foreign materials, such as tools, cleaning components, fixtures, etc., in the test apparatus. The assembly procedures shall assure that no foreign materials become lodged in the assembly.

9.3.9 In the event a situation with respect to cleaning or cleanliness should arise which is not covered in the approved cleaning procedures, it shall be brought to the attention of Transient Testing for resolution.

9.3.10 HEDL, HFEF, TREAT or any other facility handling the fuel pins are to address (if applicable), but need not be limited to the above nine items (9.3.1 through 9.3.9). It shall include all cleaning methods, precautions, approved cleaning agents, inspection procedures, acceptance requirements, sequential cleaning operations, and nonconformance reports. 


\begin{tabular}{|c|c|c|c|c|}
\hline $\begin{array}{l}\text { Hanford Engineering } \\
\text { Development Laboratory }\end{array}$ & 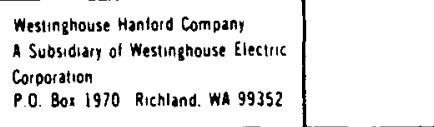 & $\begin{array}{c}\text { CORE TECHNOLOGY AND SAFETY } \\
\text { ENGINEERING TEST PLAN }\end{array}$ & $\begin{array}{r}\text { REVISION } \\
1 \\
1\end{array}$ & DATE \\
\hline $\begin{array}{l}\text { IEST SERIES } \\
\text { HEDL TRANS }\end{array}$ & ISIENT TEST PROGRAM & SERIES TEST PLAN & APPROVED & \\
\hline SECTION TITLE & SSEMBLY REQUIREMENTS & & $\begin{array}{r}\text { SECTION NO. } \\
10.0\end{array}$ & $\begin{array}{r}\text { PAGE NO. } \\
1\end{array}$ \\
\hline
\end{tabular}

10.0 ASSEMBLY REQUIREMENTS

10.1 LOOP ASSEMBLY, OUTF ITTING AND PROOF TESTING REQUIREMENTS

10.1.1 Loop Assembly Requirements

Assembly of the HEDL loops components will be performed by Fabrication and Assembly $(F \& A)$. An assembly plan shall be prepared by $F \& A$ for each loop, which includes the specific step-wise assembly, inspection points, hold points, references to operating and inspections procedures and provisions for the documentation of completed work. The assembly plan is to be reviewed and approved by Transient Testing (TT) and Fuel Quality Engineering (FQE). FQE shall review for inspection and hold points. TT shall review for design conformance. F\&A shall review for specific procedures, fabricability, etc. Specific assembly requirements are as follows:

10.1.1.1 Hold points and cautionary notes specified on the drawings are to be addressed in the assembly plan.

10.1.1.2 Cleanliness requirements of Section 9.0 are to be addressed in the assembly plan when applicable.

10.1.1.3 The assembly plan shall specifically call out the order of assembly of each component to prevent the possibility of making a permanent attachment which may interfere with the function of another component. Also, the assembly plan is to identify all required inspections and data recording requirements.

10.1.1.4 Conditions may arise during the course of a development program that cannot be anticipated and require changes to certain procedural steps. These changes are to be written into the assembly plan, signed, and dated by the cognizant engineer. Affected organizations, including TT and FQE, will be advised of all handwritten changes and approvals obtained in accordance with the requirements of Section 10.1 . 


\begin{tabular}{|c|c|c|c|c|}
\hline $\begin{array}{l}\text { Hanford Engineering } \\
\text { Development Laboratory }\end{array}$ & 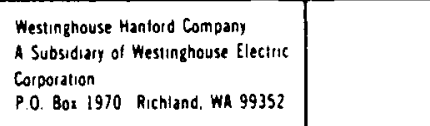 & $\begin{array}{c}\text { CORE TECHNOLOGY AND SAFETY } \\
\text { ENGINEERING TEST PLAN }\end{array}$ & $\begin{array}{r}\text { REVISION } \\
1\end{array}$ & DATE \\
\hline $\begin{array}{l}\text { TEST SERIES } \\
\text { HEDL TRAN }\end{array}$ & ISIENT TEST PROGRAM & SERIES TEST PLAN & \multicolumn{2}{|l|}{ APPROVED } \\
\hline \multicolumn{2}{|r|}{ ASSEMBLY REQUIREMENTS } & & $\begin{array}{r}\text { SECTION NO } \\
10.0\end{array}$ & $\begin{array}{r}\text { PAGE NO. } \\
2\end{array}$ \\
\hline
\end{tabular}

10.1.1.5 Modifications or repairs such as welding, bending, heat treating, cleaning, machining, cutting, temporary attachment, nondestructive testing or any other process which might alter the function of the loop components are strictly prohibited unless specified in this engineering test plan, test plan addenda, DFC, or approved assembly plan.

10.1.1.6 The loop components are to be placed in protective storage when the components are not in the process of assembly.

10.1.1.7 All measurements shall be performed with instruments calibrated to RDT F3-2, "Calibration System Requirements."

10.1.1.8 Demagnetization of the flow sensor magnets can possibly occur if weld current is passed through the sensor. Placement of welding electrical circuit attachments shall be addressed in the assembly plan.

10.1.1.9 All completed subassemblies and related components (hood and containment can) shall be leak tested for acceptability in accordance with the requirements of Section 8.1 .3 .4 .4 .

10.1.1.10 Each single pin test loop shall be uniquely identified on the top plate as shown on Drawing H-3-47129. Each loop shall be identified by the designation SPTL-1, SPTL-2, etc.

10.1.1.11 The final assembly shall meet the dimensional requirements as specified on Drawing $\mathrm{H}-3-47080$, Sheet 1. Quality Assurance verification of the as-built dimensions is required.

10.1.1.12. Those components specified in Table 10.1.1 shall be radiographically and dye penetrant examined prior to welding in accordance with the requirements of RDT F3-6. Dye penetrant examination acceptance standards shall be in accordance with paragraph NB5350 of Section III of the 1980 ASME code. The radiographs shall be for information only and shall not be evaluated on the accept or reject requirements. Any indications found will be reviewed on a case by case bas is by the Design Engineer. 


\begin{tabular}{|c|c|c|c|c|}
\hline $\begin{array}{l}\text { Hanford Engineering } \\
\text { Development Laboratory }\end{array}$ & 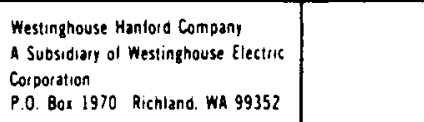 & $\begin{array}{c}\text { CORE TECHNOLOGY AND SAFETY } \\
\text { ENGINEERING TEST PLAN }\end{array}$ & $\begin{array}{r}\text { REVISION } \\
1\end{array}$ & DATE \\
\hline TEST SERIES & SIENT TEST PROGRAM & SERIES TEST PLAN & \multicolumn{2}{|l|}{ APPROVED } \\
\hline \multicolumn{2}{|r|}{ ASSEMBLY REQUIREMENTS } & & $\begin{array}{r}\text { SECTION NO } \\
10.0\end{array}$ & $\begin{array}{r}\text { PAGE NO. } \\
3\end{array}$ \\
\hline
\end{tabular}

10.1.1.13 Upon completing the assembly of each SPTL, Fabrication and Assembly shall determine and inform Transient Testing and Component Fabrication of the perpendicular distance from the top flange, Drawing No. H-3-47080, Sheet 1 , to the contact point of the $45^{\circ}$ test section seat to within 0.010 in. for each loop. Also, they are to determine the perpendicular distances from the top flange to the flow meter bracket surface and to the top of the sodium return port in the return tee. These distances will be used to determine the length of the test train assemblies.

10.1.1.14 In the event the pressure boundary components are assembled by other than a HEDL organization, detailed fabrication and handling procedures shall be submitted by the fabricator to Fabrication and Assembly (Fâ) section for their approval. Prior to initiation of fabrication and assembly of any portion of the piping subassemblies, the fabricator shall obtain a written release to fabricate. The fabrication procedures shall include, but not be limited to, sequences and procedures for material ordering, bending and forming, welding, heat treatment, cleaning, maintaining cleanliness, machining, NDT examination, weld joint identification, materials control, and testing of all parts of the piping subassemblies. The fabrication procedures shall also indicate whether fabricating operations on the subassembly are to be performed in the fabricator's shop or at the job site. Procedures shall also indicate whether any fabrication operations required are to be performed by others.

Specific qualification procedures and first article inspection, necessary to assure the requirements of Drawing $\mathrm{H}-3-47080$ will be met, shall be submitted to the $F \dot{u} A$ by the fabricator prior to start of work.

Weld preparations may have root faces specified by the fabricator as required. These root faces must be incorporated in the fabrication drawings and approved by the $F \& A$. 


\begin{tabular}{|c|c|c|c|c|c|}
\hline $\begin{array}{l}\text { Hanford Engineering } \\
\text { Development Laboratory }\end{array}$ & 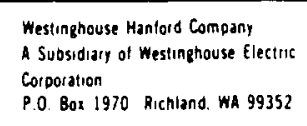 & \multicolumn{2}{|c|}{$\begin{array}{c}\text { CORE TECHNOLOGY AND SAFETY } \\
\text { ENGINEERING TEST PLAN }\end{array}$} & $\begin{array}{r}\text { REVISION } \\
1 \\
1\end{array}$ & DATE \\
\hline $\begin{array}{l}\text { TEST SERIES } \\
\text { HEDL TRAN }\end{array}$ & VSIENT TEST PRO & TESTS & SERIES TEST PLAN & \multicolumn{2}{|l|}{ APPROVED } \\
\hline \multicolumn{3}{|c|}{ ASSEMBLY REQUIREMENTS } & & $\begin{array}{r}\text { SECTION NO. } \\
10.0\end{array}$ & $\begin{array}{r}\text { PAGE NO } \\
4\end{array}$ \\
\hline
\end{tabular}

TABLE 10.1 .1

SPTL PRESSURE BOUNDARY COMPONENTS

WHICH REQUIRE RADIOGRAPHIC EXAMINATION

$\begin{array}{ll}\frac{\text { Part Number }}{\mathrm{H}-3-47080-3} & \frac{1}{\text { Description }} \\ \mathrm{H}-3-47080-4 & \text { Returure Tube } \\ \mathrm{H}-3-47080-5 & \text { Return Leg } \\ \mathrm{H}-3-47080-6 & \text { Test Section } \\ \mathrm{H}-3-47080-7 & \text { Transition Piece } \\ \mathrm{H}-3-47080-8 & \text { Lower Bend } \\ \mathrm{H}-3-47653-4 & \text { Core Tube } \\ \mathrm{H}-3-47653-5 & \text { Core Tube } \\ \mathrm{H}-3-47653-6 & \text { Core Tube } \\ \mathrm{H}-3-47653-7 & \text { Duct, Lower Flowmeter } \\ \mathrm{H}-3-47653-15 & \text { Core Tube }\end{array}$

10.1.2 Loop Outfitting and Proof Testing Requirements

Fabrication and Assembly $\left(F_{\alpha A}^{0}\right)$ is responsible for the assembly, outfitting and proof testing of the as received loop body and pump. A work plan shall be prepared which includes the specific functional requirements, procedures, traveler documents and acceptance criteria and are to be submitted to TT and FQE for approval: The general activities to be covered in this work plan shall consist of procurement, receiving, inspection, assembly, installation, calibrating, final inspection, testing and shipping of the following items for the loops:

- temperature sensors and associated readout instruments

- flow sensors and associated readout instruments

- pump coolant tubes and heat exchangers

- trace heaters and associated controllers

- insulation 


\begin{tabular}{|c|c|c|c|c|}
\hline $\begin{array}{l}\text { Hanford Engineering } \\
\text { Development Laboratory }\end{array}$ & 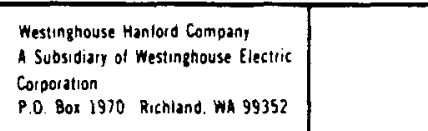 & $\begin{array}{c}\text { CORE TECHNOLOGY AND SAFETY } \\
\text { ENGINEERING TEST PLAN }\end{array}$ & $\begin{array}{r}\text { REVISION } \\
1\end{array}$ & DATE \\
\hline \multicolumn{2}{|c|}{$\begin{array}{l}\text { TEST SERIES } \\
\text { HEDL TRANSIENT TEST PROGRAM }\end{array}$} & SERIES TEST PLAN & \multicolumn{2}{|l|}{ APPROVED } \\
\hline \multicolumn{2}{|r|}{ ASSEMBLY REQUIREMENTS } & & $\begin{array}{r}\text { SECTION NO. } \\
10.0\end{array}$ & $\begin{array}{r}\text { PAGE NO. } \\
5\end{array}$ \\
\hline
\end{tabular}

- assembly of the piping and outer can

- neutron flux filter material

- electrial and instrument leads

- sodium pump controllers and power supply

- sodium filling of the loop

- AliP pump puli test.

Specific outfitting and proof testing requirements are as follows.

10.1.2.1 Hold points and cautionary notes specified on the drawings are to be addressed in the work plan.

10.1.2.2 Cleanliness requirements of Section 9.0 are to be addressed in the work plan when applicable.

10.1.2.3 The work plan shall specifically call out the order of assembly of each component to prevent the possibility of making a permanent attachment which may interfere with the function of another component. Also, the work plan is to identify all required inspections and data recording requirements.

10.1.2.4 Instrumentation (thermocouples, flow level and pressure sensors), circuit resistances, leg-to-leg and leg-to-sheath, are to be measured before installation and after each operation involving the instrumenation, its splice, flexible leads or connectors. Any unexpected or unreasonable change in resistance shall be evaluated by the responsible assembly engineer and the TT cognizant engineer. Only a low voltage instrument (multimeter type) is to be used to measure the resistance of each circuit. Less than a $10 \%$ variation in the initial resistance measurement is acceptable.

10.1.2.5 Conditions may arise during the course of a development program that cannot be anticipated and require changes to certain procedural steps. These changes are to be written into the work plan, signed, and dated by the cognizant engineer. Affected organizations, including TT and FQE, will be advised of all handwritten changes and approvals obtained in accordance with the requirements of Section 10.1 . 


\begin{tabular}{|c|c|c|c|c|}
\hline $\begin{array}{l}\text { Hanford Engineering } \\
\text { Development Laboratory }\end{array}$ & 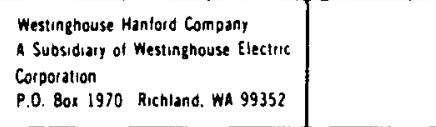 & $\begin{array}{c}\text { CORE TECHNOLOGY AND SAFETY } \\
\text { ENGINEERING TEST PLAN }\end{array}$ & $\begin{array}{r}\text { REVISION } \\
1\end{array}$ & DATE \\
\hline $\begin{array}{l}\text { TEST SERIES } \\
\text { HEDL TRANS }\end{array}$ & ISIENT TEST PROGRAM & $\begin{array}{l}\text { TESTS } \\
\text { SERIES TEST PLAN }\end{array}$ & APPROVED & \\
\hline CTION TITLE & SSEMBLY REQUIREMENTS & & $\begin{array}{r}\text { SECTION NO } \\
10.0\end{array}$ & $\begin{array}{r}\text { PAGE NO } \\
6\end{array}$ \\
\hline
\end{tabular}

10.1.2.6 Modifications or repairs such as welding, bending, heat treating, cleaning, machining, cutting, temporary attachment, nondestructive testing or any other process which might alter the function of the test train components are strictly prohibited unless specified in this engineering test plan, test plan addenda, DFC, or approved work plan.

10.1.2.7 Care shall be taken when handling the loop subassemblies. The instrumentation leads shall be protected as best possible during all operations on or about the assemblies.

10.1.2.8 The loop subassemblies are to be placed in protective storage when the components, etc., are not in the process of outfitting or proof testing.

10.1.2.9 Care is to be taken not to burn through any instrumentation leads during the welding operations.

10.1.2.10 All measurements shall be performed with instruments calibrated to RDT F3-2, "Calibration System Requirements."

10.1.2.11 Demagnetization of the flow sensor magnets can possibly occur if weld current is passed through the sensor. Placement of welding electrical circuit attachments shall be addressed in the work plan.

10.1.2.12 Identification of the instrumentaton leads shall be maintained at al1 times.

10.1.2.13 The loop shall be filled with sodium, which meets the purity level of RDT M13-1T. This level of purity shall be maintained as best practicable throughout all subsequent operations. Component fabriction is to verify the test train volume prior to loading into a loop. 


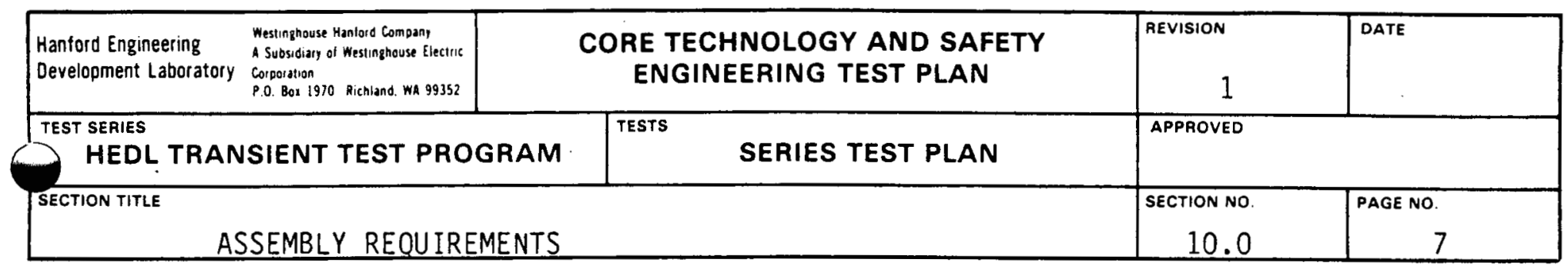

10.1.2.14 The loop cover gas purity shall meet the purity requirements specified in ROT M14-1.

10.1.2.15 The completed outfitted loop shall be pressure tested at $2625 \pm 100$ psia at $800 \pm{ }_{0}^{100} \mathrm{~F}$ sodium temperature in accordance with Section III of the ASME Boiler and Pressure Vessel Code.

10.1.2.16 The final outfitted loop shall meet the requirements as specified on Drawings $\mathrm{H}-3-47129, \mathrm{H}-3-47130$ and $\mathrm{H}-3-47131$ and this document.

10.1.2.17 The neutron filter configuration and materials will be determined by Transient Testing and the information provided to Fabricatin and Assembly.

10.1.2.18 The ALIP and Flow Sensor Assembly, Drawing H-3-47656, shall be calibrated in flowing sodium to requirements determined by Transient Testing and Fabrication and Assembly.

10.1.2.19 A sodium flow direction method is required. A scheme is to be developed by F\&A which will produce a positive flow sensor signal when the flow is in the forward direction.

\subsubsection{ALIP and Flow Sensor Assembly Requirements}

10.1.3.1 Assembly of the ALIP and flow sensors will follow the sequence as described on the assembly/follower cards. Paragraph 10.1 .1 is applicable with the exception at sub-paragraphs 10.1.1.9, 10.1.1.10 and 10.1.1.13. The final assembly shall meet the dimensional requirements as specified on drawing H-3-47084. QA verification of the as-built dimensions is required. Paragraph 10.1 .2 is also applicable. 


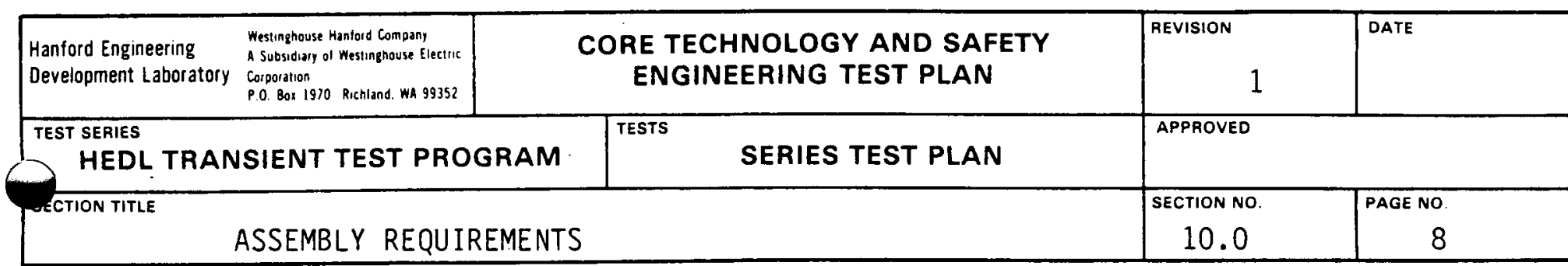

10.1.3.2 The ALIP and flow sensors assembly/follower cards shall be written to include the following:

Assembly sequence

QA hold points, etc.

Procedures, as needed

Measurements recording

These cards will be approved by Fabrication and Assembly, Fuels Quality Engineering and Transient Testing prior to usage.

10.1.3.3 Special fixturing will be required for the lamination, coil, and insulation (Multi-foil) tube subassemblies. After completing the dual-coil subassemblies, a spacer shall be placed between the coils to prevent movement which could cause coil or Macor damage. The dual-coil winding tool shall be used for coil assembly.

The lamination stacking tool shall be used to assemble the lamination subassemblies. A small rubber hammer can be used to properly align each piece before tightening of the mounting screws. The laminations must be oxidized prior to assembly by heat treating at $700^{\circ} \mathrm{F}$ in air for four hours for a thin insulating layer to form. Care must be taken not to scratch these oxidized surfaces.

10.1.3.4 The following nomenclature is assigned to the ALIP internal thermocouples:

$\begin{array}{ll}\frac{T C \#}{T C-21} & \frac{1}{\text { Inlet ALIP Tube }} \\ \text { TC-22 } & \text { Outlet ALIP Tube } \\ T C-23 & \text { Mid-tube right } \\ T C-24 & \text { Mid-tube left } \\ T C-25 & \text { Mid-coil }\end{array}$

The thermocouples will be appropriately tagged during assembly. 


\begin{tabular}{|c|c|c|c|c|}
\hline $\begin{array}{l}\text { Hanford Engineering } \\
\text { Development Laboratory }\end{array}$ & 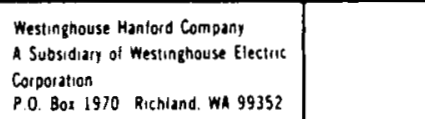 & $\begin{array}{c}\text { CORE TECHNOLOGY AND SAFETY } \\
\text { ENGINEERING TEST PLAN }\end{array}$ & $\begin{array}{r}\text { REVISION } \\
1\end{array}$ & DATE \\
\hline \multicolumn{2}{|c|}{$\begin{array}{l}\text { TEST SERIES } \\
\text { HEDL TRANSIENT TEST PROGRAM }\end{array}$} & SERIES TEST PLAN & \multicolumn{2}{|l|}{ APPROVED } \\
\hline CTION TITLE & SEMBLY REQUIREMENTS & & $\begin{array}{r}\text { SECTION NO. } \\
10.0 \\
\end{array}$ & $\begin{array}{r}\text { PAGE NO. } \\
9\end{array}$ \\
\hline
\end{tabular}

10.1.3.5 All flow sensor leads shall be positively identified during assembly to prevent any change or loss of identification.

\subsection{TEST TRAIN ASSEMBLY REQUIREMENTS}

Assembly of the test train components will be performed by Component Fabrication (CF). An assembly plan shall be prepared by CF for each test train which includes the specific step-wise assembly, inspection points, hold points, references to operating and inspection procedures and provisions for the documentation of completed work. The assembly plan is to be reviewed by Transient Testing (TT) and Fuel Quality Engineering (FQE). FQE shall review for inspection and hold points. TT shall review for design conformance. CF shall review for specific procedures, fabricability, etc.

The assembly of the test trains for the HEOL Transient Test Program shall be in accordance with the drawings referenced in Appendix $C$ and the specific assembly requirements that follow.

10.2.1 The work instructions shall specifically call out the order of assembly of each component to prevent the possibility of making a permanent attachment, which may interfere with the function of another component. Also, the work instructions are to identify all required inspections and data recording requirements.

10.2.2 The test train thermocouples are to be positioned and recorded as shown on the engineering drawings. Sufficient thermocouple length shall be allowed for assembly and differential thermal expansion.

10.2.3 The thermocouple circuit resistances, leg-to-leg and leg-to-sheath, are to be measured before installation and after each operation involving the thermocouples, its splice, flexible leads or connectors. Any unexpected or unreasonable change in resistance shall be evaluated by the responsible fabrication engineer and the Transient Testing cognizant engineer. Only a 


\begin{tabular}{|c|c|c|c|c|}
\hline $\begin{array}{l}\text { Hanford Engineering } \\
\text { Development Laboratory }\end{array}$ & 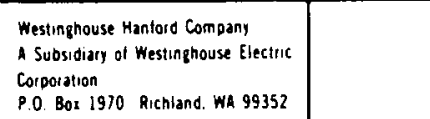 & $\begin{array}{c}\text { CORE TECHNOLOGY AND SAFETY } \\
\text { ENGINEERING TEST PLAN }\end{array}$ & $\begin{array}{r}\text { REVISION } \\
1\end{array}$ & DATE \\
\hline \multicolumn{2}{|c|}{ TEST SERIES } & SERIES TEST PLAN & \multicolumn{2}{|l|}{ APPROVED } \\
\hline \multicolumn{3}{|c|}{$\begin{array}{l}\text { SECTION TITLE } \\
\text { ASSEMBLY REQU IREMENTS }\end{array}$} & $\begin{array}{r}\text { SECTION NO } \\
10.0\end{array}$ & $\begin{array}{r}\text { PAGE NO. } \\
10\end{array}$ \\
\hline
\end{tabular}

low voltage instrument (multimeter type) shall be used to measure the resistance of each thermocouple. Less then a 10\% variation in the initial resistance measurements is acceptable.

10.2.4 The straightness of the test train is of major importance. The overall deviation from the straightness of the baffle assembly shall not exceed $0.020 \mathrm{in.}$, and the straightness distance between the locking tee assembly (bayonet assembly) and the nose piece shall not exceed 0.030 in. The straightness between the bottom of the nose piece, Part No. 36, to the top of the outer tube just below the flow sensor, Part No. 6, shall be within $0.010 \mathrm{in.}$ for final assembiy.

10.2.5 The annulus between the flow tube and the outer wall of the test section assembly is to be leak tight and inert. Just prior to making the final weld(s) to the test section assembly, the annulus is to be pumped down and back-filled with argon at least three times. Following the last backfill, the annulus is to be pumped down and back-filled with a helium-argon mixture (less than $10 \%$ helium) and seal welded. The subassembly is then to be leak tested. A helium leak rate greater than $1.0 \times 10^{-8} \mathrm{Scc} / \mathrm{sec}$ constitutes an unacceptable seal.

10.2.6 The cavity in which the flow sensor wires are attached is to be leak tight and inert. Just prior to welding the flow sensor assembly into the test section, the cavity is to be pumped down and back-filled with heliumargon mixture (less than $10 \%$ helium) and seal welded. The seal welded subassembly is then to be leak tested. A helium leak rate greater than $1.0 \times 10^{-8} \mathrm{Scc} / \mathrm{sec}$ constitutes an unacceptable seal.

10.2.7 The test train identification numbers shall be stamped or etched on the upper position of the top closure flange and on the side of the bayonet key at the bottom of the baffle subassembly after the respective test train has been assembled. The markings shall be a minimum of $1 / 8 \mathrm{in}$. high. The identification numbers shall be SPTT-1, SPTT-2, etc, numbering the series test trains sequentially. 


\begin{tabular}{|c|c|c|c|c|}
\hline $\begin{array}{l}\text { Hanford Engineering } \\
\text { Development Laboratory }\end{array}$ & 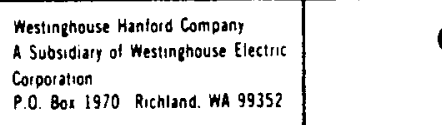 & $\begin{array}{c}\text { CORE TECHNOLOGY AND SAFETY } \\
\text { ENGINEERING TEST PLAN }\end{array}$ & $\begin{array}{r}\text { REVISION } \\
1\end{array}$ & DATE \\
\hline $\begin{array}{l}\text { TEST SERIES } \\
\text { HEDL. TRAN }\end{array}$ & ISIENT TEST PROGRAM & SERIES TEST PLAN & \multicolumn{2}{|l|}{\begin{tabular}{|l|} 
APPROVED \\
\end{tabular}} \\
\hline \multicolumn{2}{|r|}{ ASSEMBLY REQUIREMENTS } & & $\begin{array}{r}\text { SECTION NO } \\
10.0\end{array}$ & $\begin{array}{r}\text { PAGE NO. } \\
11\end{array}$ \\
\hline
\end{tabular}

10.2.8 The test train overall length is of major importance with respect to the required seal force at the nose piece - test section seat interface. The test train is designed to have a minimum of 0.053 in. compression when installed in the loop. However, tolerance stackup for the loop body weldment or the test train could result in a situation where the test train is either not sealed under compression or it cannot be sealed because the test train is too long. As a result, adjustment of some test train component lengths is usually required to achieve the minimum compression distance of $0.053 \mathrm{in}$. Located on the assembly drawing (Sheet 1) are the reference locations, which are used to obtain the required test train length adjustment. The assembly instructions shall specify what sequence of measurements, recorded distances, adjustments, hold points, etc., shall be taken to achieve the required test train length. As a minimum, the as-built reference locations and overall length shown on the assembly drawing (Sheet 1) shall be recorded.

10.2.9 The two parallel Belleville washers to provide the seal force for the exit weldment assembly seal ring are to be compressed by the hex nut until they are in the flat position. The exit weldment assembly shall be perpendicular to the closure flange seal face within 0.010 inches.

10.2.10 To ensure that the test train pressure boundary components can withstand rated loop proof test conditions of 2625 psi -100 psi pressure at $800^{\circ} \mathrm{F}={ }_{0}^{100} \mathrm{~F}$, the pressure boundary components shall be hydrostatically tested at the same pressure-temperature conditions as the loop. The hydrostatic test shall be in accordance with Section III of the Code. The hydrostatic test shall be 3350 psi \pm 50 psi pressure at room temperature. The pressure boundary components consist of the exit weldment assembly thermocouple leads, seal ring, closure flange, Belleville washers, flat washer and hexagonal nut. Within two to three hours after the hydrostatic test, the thermocouples are to be flash heated to $250^{\circ} \mathrm{F} \pm 25 \mathrm{~F}^{\circ}$. 


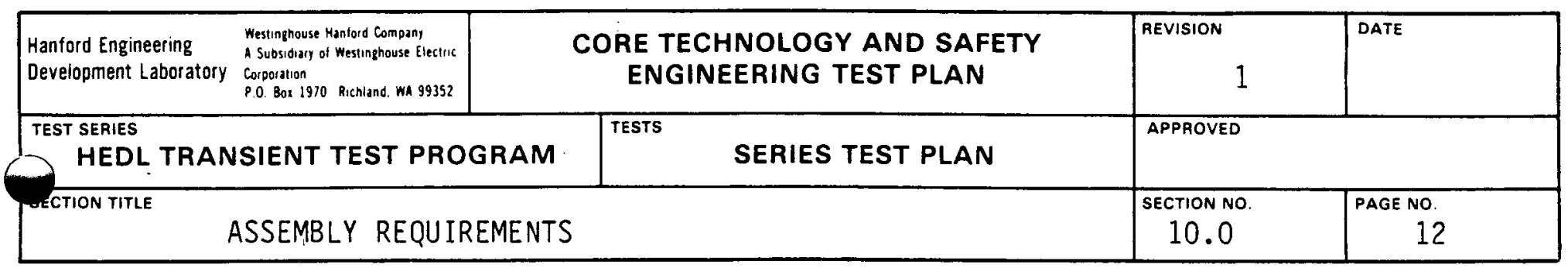

10.2.11 A dummy fuel pin with the same dimensions as the test element is to be completely inserted and unloaded in the test train prior to shipping to ensure that the test element $c$ an be loaded at HFEF without undue problems.

10.2.12 The Cannon straight plug thermocouple connector (see Section 6.2.13) shall be provided to Component Fabrication by Fabrication and Assembly for C06 and $\mathrm{CO} 7$ and the connector will be provided by ANL for C04 and C05. The connector plug is to mate up with the receptacle in the top plate of the loop after insertion in the loop. The connector pin assignments are specified on Drawing H-3-47131. The thermocouple lead length between the exit point of the TC exit assembly, Part No. 2, and the connector plug shall be 11.0 - 1.0 inches. The lead splices, see Drawing $\mathrm{H}-3-47103$, Sheet 1 , are to be staggered and the lead wires banded in such a manner so the lead wires can be bent $180^{\circ}$ at a location of $5.0 \pm 1.0 \mathrm{in}$. above the TC exit assembly.

10.2.13 The set screw hold on the top closure flange shall be made after final assembly. It shall be $135^{\circ}-1^{\circ}$ from the center of the small index key.

10.2.14 Component Fabrication shall determine the displacement volume of the final assembled test train by immersion in alcohol to the depth specified by Transient Testing.

10.2.15 The pairing of the flow sensor wires is as follows: a. Flow sensor FS-1 will use the two chromel wires on opposite sides
of the sensor.

b. Flow sensor FS-2 will use the two alumel wires on opposite sides of the sensor.

\subsection{FUEL PIN PREPARATION REQUIREMENTS}

Postirradiation Testing shall be responsible for the final preparation of all fuel pins at HEDL. 


\begin{tabular}{|c|c|c|c|c|c|}
\hline $\begin{array}{l}\text { Hanford Engineering } \\
\text { Development Laboratory }\end{array}$ & 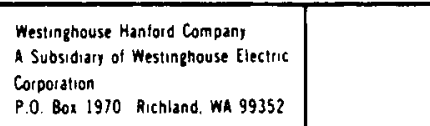 & \multicolumn{2}{|c|}{$\begin{array}{c}\text { CORE TECHNOLOGY AND SAFETY } \\
\text { ENGINEERING TEST PLAN }\end{array}$} & $\begin{array}{r}\text { REVISION } \\
1\end{array}$ & DATE \\
\hline \multicolumn{2}{|c|}{$\begin{array}{l}\text { TEST SERIES } \\
\text { HEDL TRANSIENT TEST PROGRAM }\end{array}$} & TESTS & SERIES TEST PLAN & \multicolumn{2}{|l|}{ APPROVED } \\
\hline CTION TITLE & SSEMBLY REQUIREMENTS & & & $\begin{array}{r}\text { SECTION NO } \\
10.0\end{array}$ & $\begin{array}{r}\text { PAGE NO. } \\
13\end{array}$ \\
\hline
\end{tabular}

10.3.1 All fuel pins are to be maintained in a position such that the fuel pin longitudinal axis is either horizontal or vertical with the top end up.

Care should be taken not to handle the fuel pin in the fuel pin fuel column region. Preferably, the fuel pin should be handled by the ends, but it is acceptable to handle the non-fueled cladding regions if clean padded manipulators are used.

10.3.2 Clean the entire fuel pin surface prior to nondestructive examination.

10.3.3 Nondestructive examination shall consist of the following:

a. Visual Examination - The cognizant Transient Testing engineer or representative shall examine all specified irradiated test pins and record the fuel pins' surface condition. The findings shall be described qualitatively and recorded in the fuel pins logbook.

b. Full length photography of the irradiated pins in their plane of max imum bow.

c. Gross gamma scan the full length of the irradiated fuel pins. I sotopic gamma scan the region from $1,1 / 2$ in. above to $11 / 2$ in. below the fuel column for ${ }^{137} \mathrm{Cs}, \mathrm{Ru} / 106 \mathrm{Rh}$, and $\mathrm{Zr} / 95 \mathrm{Nb}$ isotopes. Notify the cognizant Transient Testing engineer upon completion so that it can be determined if further gamma scans are required.

d. Continuous profilometry and eddy current measurements are to be made for each irradiated fuel pin over the maximum length obtainable for radial increments of $0^{\circ}, 45^{\circ}, 90^{\circ}, 135^{\circ}$ and $180^{\circ}$. 


\begin{tabular}{|c|c|c|c|c|}
\hline $\begin{array}{l}\text { Hanford Engineering } \\
\text { Development Laboratory }\end{array}$ & 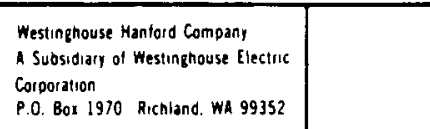 & $\begin{array}{c}\text { CORE TECHNOLOGY AND SAFETY } \\
\text { ENGINEERING TEST PLAN }\end{array}$ & $\begin{array}{r}\text { REVISION } \\
1\end{array}$ & DATE \\
\hline \multicolumn{2}{|c|}{$\begin{array}{l}\text { TEST SERIES } \\
\text { HEDL TRANSIENT TEST PROGRAM }\end{array}$} & SERIES TEST PLAN & \multicolumn{2}{|l|}{ APPROVED } \\
\hline \multicolumn{3}{|c|}{ SHIPP ING, PACKAG ING AND HANDLING REOUIREMENTS } & $\begin{array}{r}\text { SECTION NO. } \\
11.0\end{array}$ & $\begin{array}{r}\text { PAGE NO. } \\
1\end{array}$ \\
\hline
\end{tabular}

\subsection{SHIPPING, PACKAGING AND HANDLING REQUIREMENTS}

The loops and test trains are to be fabricated at HEDL and shipped to the HFEF Facility for final assembly and loading. After completion of each test at TREAT, the loop will be returned to HFEF for post-test examination and further disposition. Final processing of the test articles at HFEF will depend upon the test's performance and/or Safety Test Program examination requirements. In most instances, the loop will contain failed fuel pins and, in those cases, the loop will most likely be discarded after each test. The test trains are to be discarded after completion of each test. The following are the specific shipping, packaging and handling requirements for each major component.

\subsection{TREAT LOOPS}

11.1.1 The requirements specified in Section 5, Preparation for Delivery, of RDT F6-11, Fabrication and Installation of Piping Subassemblies for Liquid Metal Services, shall pertain to the handling, shipping and packaging of the loops with the following exceptions:

a. Fabricator is defined to be Fabrication and Assembly, HFEF or TREAT, and purchaser Transient Testing.

b. Delete 5.1.2.2, "Documentation."

c. Those organiztions specified in Section 11.1.1.a shall meet the requirements specified in Appendix $B$ of TC-1361 in lieu of Section 5.1.3 of RDT F6-11, if their activities involve lifting the loop.

11.1.2 The TREAT loop shipping containers must be capable of being reused.

11.1.3 Transient Testing shall designate the shipping date as determined from HEDL-TREAT schedule agreements.

11.1.4 Storage, loading and unloading procedures for the loops are to be prepared by Fabrication and Assembly, HFEF and TREAT and approved by Transient Testing. 


\begin{tabular}{|c|c|c|c|c|}
\hline $\begin{array}{l}\text { Hanford Engineering } \\
\text { Development Laboratory }\end{array}$ & 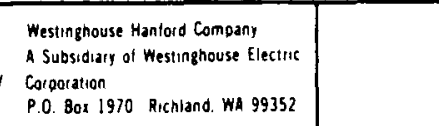 & $\begin{array}{c}\text { CORE TECHNOLOGY AND SAFETY } \\
\text { ENGINEERING TEST PLAN }\end{array}$ & $\begin{array}{r}\text { REVISION } \\
1 \\
1\end{array}$ & DATE \\
\hline \multicolumn{2}{|c|}{$\begin{array}{l}\text { TEST SERIES } \\
\text { HEDL TRANSIENT TEST PROGRAM }\end{array}$} & SERIES TEST PLAN & \multicolumn{2}{|l|}{ APPROVED } \\
\hline \multicolumn{2}{|c|}{ SHIPP ING, PACKAGING AND HANDLING REOUIREMENTS } & HANDLING REOUIREMENTS & $\begin{array}{r}\text { SECTION NO. } \\
11.0\end{array}$ & $\begin{array}{r}\text { PAGE NO. } \\
2\end{array}$ \\
\hline
\end{tabular}

11.1.5 The loops will be filled with sodium at HEDL prior to being shipped to the Idaho Facility. However, differences in test train volumes may require the addition or removal of sodium at HFEF, if the loops require reuse.

\subsection{TEST TRAIN ASSEMBLY}

11.2.1 Transient Testing shall designate the shipping date as determined from HEDL-TREAT schedule agreements.

11.2.2 Component Fabrication and TREAT shall prepare handling and storage procedures for the test train. Minimum handling requirements are specified in Appendix B of TC-1361.

\subsection{TEST ELEMENTS}

11.3.1 Radiation monitoring and shipment reports for each fuel pin shall be processed by Component Fabrication or Shielded Materials Facility Sections and the shipment coordinated with Nuclear Materials Management.

11.3.2 Transient Testing, in cooperation with Nuclear Materials Management, shall schedule the fuel pin shipping container.

11.3.3 Care should be taken to avoid damaging any component during loading and unloading. Care should be taken not to handle the fuel pin in the fuel column region. All fuel pins are to be maintained in a position such that the fuel pin longitudinal axis is either horizontal or vertical with the top end up. Preferably, the fuel pin should be handled by the ends, but it is acceptable to handle the nonfueled cladding region if clean padded manipulators are used. Component Fabrication, Shielded Materials Facility Sections, HFEF, TREAT, or any other facility which may handle the fuel pins, shall prepare handling and storage procedures for the test elements. 


\begin{tabular}{|c|c|c|c|c|}
\hline $\begin{array}{l}\text { Hanford Engineering } \\
\text { Development Laboratory }\end{array}$ & 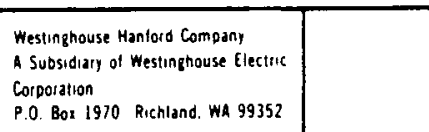 & $\begin{array}{c}\text { CORE TECHNOLOGY AND SAFETY } \\
\text { ENGINEERING TEST PLAN }\end{array}$ & $\begin{array}{r}\text { REVISION } \\
1\end{array}$ & DATE \\
\hline \multicolumn{2}{|c|}{$\begin{array}{l}\text { TEST SERIES } \\
\text { HEDL TRANSIENT TEST PROGRAM }\end{array}$} & SERIES TEST PLAN & \multicolumn{2}{|l|}{ APPROVED } \\
\hline \multicolumn{3}{|c|}{ PRE - AND POST-TRANSIENT REOUIREMENTS } & $\begin{array}{r}\text { SECTION NO. } \\
12.0 \\
\end{array}$ & $\begin{array}{r}\text { PAGE NO } \\
1 \\
\end{array}$ \\
\hline
\end{tabular}

12.0 PRE- AND POST-TRANSIENT REQUIREMENTS

12.1 HFEF AND TREAT OPERATIONAL REQUIREMENTS

12.1.1 The fuel pins shall be loaded into the test train at HFEF. The cognizant Transient Testing engineer or designated representative shall be present during the fuel pin loading operation. The cognizant engineer will perform a visual examination to determine if any shipping damage has occurred to the test apparatus. Corrective action will be taken as specified in the Test Operating Manual or the Loop Operating Manual.

12.1.2 Prior to and after loading the fuel pins in the test train and loading of the test train assembly in the loop at HFEF, resistance measurements shall be taken on all test train and loop thermocouples and heaters and reviewed by the cognizant Transient Testing engineer. Prior to installing the loop into the reactor, all preinsertion checks of operating and performance of the loop instrumentation and equipment are to be conducted. Preinsertion checks are to be specified in the Test Operating Manual and the Loop Operating Manual supplied to the TREAT manager.

12.1.3 The test train assembly is to be pretransient radiographed to verify the relative location of the test train thermocouples prior to loading of the test train in the loop.

12.1.4 The cleanliness requirements of Section 9.3 are to be addressed when applicable.

12.1.5 After completion of radiography and cleaning of the loaded test train, the test train is to be loaded into the loop using the loading withdrawal $(L / W)$ pipe. The test train is to be purged with argon at $225^{\circ} \mathrm{F} \pm 25 \mathrm{~F}^{\circ}$ for a period of 2 hrs prior to loading in the loop. An argon cover gas is to be applied to the loops sodium free surface during all loading and unloading operations. The argon purge gas shall meet the purity requirement of RDT M14-1. 


\begin{tabular}{|c|c|c|c|c|}
\hline $\begin{array}{l}\text { Hanford Engineering } \\
\text { Development Laboratory }\end{array}$ & 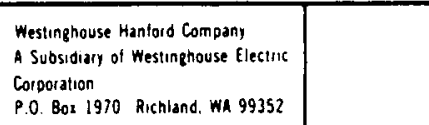 & $\begin{array}{l}\text { ORE TECHNOLOGY AND SAFETY } \\
\text { ENGINEERING TEST PLAN }\end{array}$ & $\begin{array}{r}\text { REVISION } \\
1 \\
1\end{array}$ & DATE \\
\hline $\begin{array}{l}\text { TEST SERIES } \\
\text { HEDL TRAN }\end{array}$ & ISIENT TEST PROGRAM & SERIES TEST PLAN & \multicolumn{2}{|l|}{\begin{tabular}{|l} 
APPROVED \\
\end{tabular}} \\
\hline \multicolumn{3}{|c|}{ PRE- AND POST-TRANSIENT REOUIREMENTS } & $\begin{array}{r}\text { SECTION NO. } \\
12.0\end{array}$ & PAGE NO. \\
\hline
\end{tabular}

Procedures for loading of the fuel pins and the test train assembly shall be prepared by HFEF in response to HEDL's written requirements and approved by Transient Testing. The test train is to be inserted into the 10op and sealed by means of the closure flange clamp and seal ring. The seal is to be leak tight to $1.0 \times 10^{-6} \mathrm{scc} / \mathrm{sec}$ of helium. A pressure-plenum volume check is to be conducted after completion of the closure flange leak check. The test train instrumetation is to be connected, the hood components installed, and hood and loop $c$ an is to be helium leak tested for a positive seal.

12.1.6 The test section thermocouple resistances shall be measured and recorded after the transient test. The thermocouple circuit resistance, leg-to-leg and leg-to-sheath, are to be measured using a low voltage instrument only (multimeter type).

12.1.7 The transient test in TREAT shall be performed by TREAT facility personnel in a manner specified in the test operating manual. All attempts are to be made to fulfill the requirements specified therein. Any variations from the procedures are to be reported to Transient Testing.

12.1.8 Test section instrumentation and the reactor instantaneous and integrated power shall be monitored on high speed recorders during the transient test.

12.1.9 All HEDL-supplied instrumentation at TREAT shall be calibrated to RDT F3-2. Other instrumentation calibration shall be as specified in the test operating manual.

12.1.10 Measurements shall be performed with instruments calibrated to RDT F3-2. Calibration labels or calibration logs for each instrument shall be placed directly on the equipment or in the immediate vicinity. In the event certain instruments cannot be calibrated to RDT F3-2, then a calibration procedure shall be prepared and approved by the HFEF and TREAT Quality Assurance personnel. 


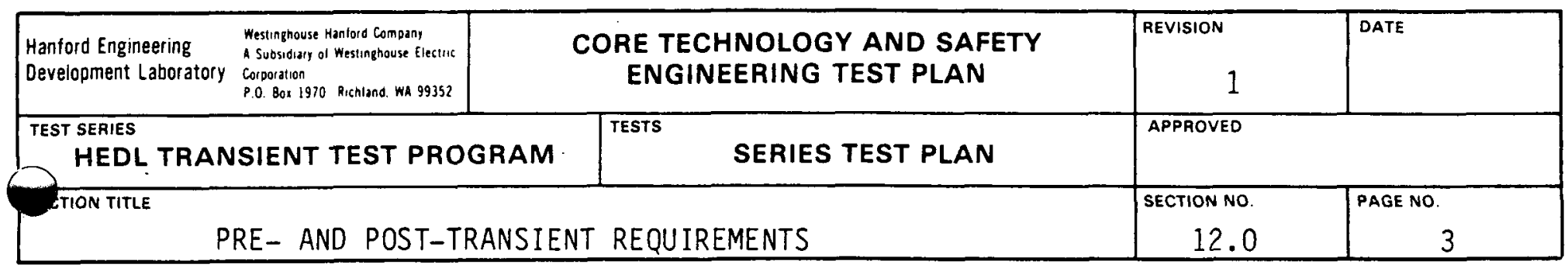

12.1.11 After completion of an individual test, the loop with the test train is to be neutron radiographed and a loop plenum gas sample taken at TREAT. Depending upon the condition of the fuel pin, the following options are available.

A. If pin is badly breached, transfer to station $10 \mathrm{M}$ and dispose of experiment as required.

B. If fuel pin is not breached or slightly breached, remove test train from loop at HFEF decon cell. Transfer test train to station 10M and remove fuel pin.

C. Post-test examination and processing. Final processing of the test train and fuel pin will be dependent upon the test performance and/or Safety Test program examination requirements. The following options are available.

1. No further examination

2. Non-breached or slightly breached fuel pin

- Visual and Photography

- Gamma Scan

- Profilometry

- Eddy Current

- Neutron Radiograph

- Transfer to HEDL-SMF in T-3 cask if detailed examination is required.

3. Major cladding breach and/or fuel melting - fuel pin is badly damaged, melted into two or more pieces, etc. Remove sodium from the test train or loop section and perform the following, if required:

a. If fuel pin or sections can be removed from test train.

- Photograph fuel pin or sections

- Transfer to HEDL-SMF in T-3 cask, if required 


\begin{tabular}{|c|c|c|c|c|}
\hline $\begin{array}{l}\text { Hanford Engineering } \\
\text { Development Laboratory }\end{array}$ & 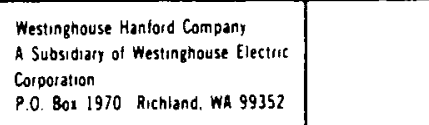 & $\begin{array}{c}\text { CORE TECHNOLOGY AND SAFETY } \\
\text { ENGINEERING TEST PLAN }\end{array}$ & $\begin{array}{r}\text { REVISION } \\
1 \\
1\end{array}$ & DATE \\
\hline $\begin{array}{l}\text { TEST SERIES } \\
\text { HEDL TRAN }\end{array}$ & ISIENT TEST PROGRAM & SERIES TEST PLAN & \multicolumn{2}{|l|}{ APPROVED } \\
\hline \multicolumn{3}{|c|}{ PRE- AND POST-TRANSIENT REQUIREMENTS } & $\begin{array}{c}\text { SECTION NO. } \\
12.0\end{array}$ & $\begin{array}{r}\text { PAGE NO } \\
4 \\
\end{array}$ \\
\hline
\end{tabular}

b. If fuel pin or sections cannot be removed from the test train

- Section test train at locations determined from neutron radiographs

- Photograph section(s) as required

- Transfer to HEDL-SMF in T-3 cask, if required.

c. Special procedures may need to be developed depending on extent of damage.

12.1.12 In the event the fuel elements have not failed, 12.1.11, Item $B$ above, the loop is usable. The following requirements are to be implemented in those instances. The test train is to be unloaded using the loop L/W pipe. During each operation requiring the removal of the loops top closure flange, the sodium free surface is to be purged with argon of RDT Standard purity. Following removal of the loaded test train, the loop's sodium volume is to be measured and sodium added or removed per HEDL's written requirements. The sodium purity shall meet the requirements of RDT M13-1. The fuel pins are to be returned to HEDL and the test train disposed of at HFEF. The same HFEF operation is to be performed following each of the tests, and, upon completion of the test series, the loops are to be stored at TREAT, or destroyed as required.

\subsection{PRE-TRANSIENT TESTING EXAMINATION AT HFEF}

The following non-destructive examinations are to be performed on the 0.230 in. diamter UK driver fuel pins at the HFEF facility:

12.2.1 Visually examine each fuel pin. Photograph unusual features which illustrate comments entered on fuel pin examination data sheet.

12.2.2 Full length photography of the fuel pin at 1 to 3 circumferential orientations may be requested, depending on the fuel pin condition. The $0^{\circ}$ orientation is defined as the $0^{\circ}$ orientation of HFEF-N fuel pin end fitting. 


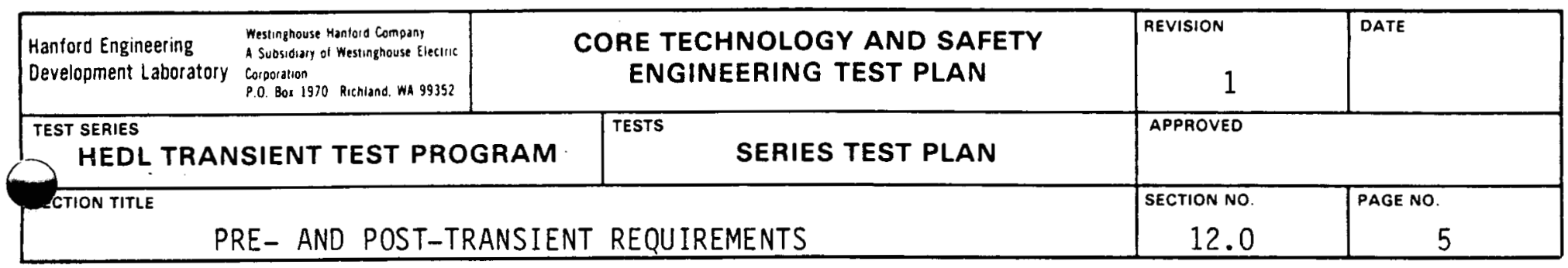

12.2.3 Perform neutron radiography on each fuel pin at $0^{\circ}$ orientation, nolders with integral scales shall be used. The full length of each pin shall be radiographed. The radiography frames shall overlap and be identified so that a full length composite of the fuel pin can be constructed. verify the fuel pin identification number.

12.2.4 Perform fuel length axial profilometry on each fuel pin at $45^{\circ}$ increments. $0^{\circ}$ orientation is the same orientation as identified in Step 12.2.2 above, the axial dimensions shall be referenced to the bottom of the fuel pin. Fuel pin diameter is $0.230 \mathrm{in}$. at the top and $0.210 \mathrm{in}$. at the bottom. Because of the two diameters, it may be necessary to measure the fuel pin in two separate steps.

12.2.5 Measure and record fuel pin bow.

12.2.6 Measure and record fuel pin length.

12.2.7 Weigh each fuel pin.

12.2.8 Perform a gross gamma scan on each fuel pin. The scan shall utilize a 0.020-in. slit width, and the measurements shall be made at $0.020-i n$. increments over the 36-in. long fuel column plus $2-i n$. above and below the fuel column.

12.2.9 Perform $\mathrm{Zr}-\mathrm{Nb}^{95} \mathrm{Cs}^{137} \mathrm{Rh}-\mathrm{Ru}{ }^{106}$ isotopic scans on each fuel pin. The scan shall utilize a 0.020-in. slit width and the measurements shall be made at 0.020-in. increments over the same region as the gross gamma scan.

\subsection{POST-TRANSIENT TESTING EXAMINATION AT HEDL}

The test objective for the PFR/TREAT program is to obtain data and information related to failure time, location and initial fuel dispersal. As a consequence, a majority of the test fuel pins will be breached and, most 
Hanford Engineering

Development Laboratory

Westunghouse Hantord Compan

A Subsidiay of Westunghouse Electirs

Corporation

P.0. Bo1 1970 Richland. Wh 99352

TEST SERIES

HEDL TRANSIENT TEST PROGRAM

CCTION TITLE

PRE- AND POST-TRANSIENT REQUIREMENTS

CORE TECHNOLOGY AND SAFETY ENGINEERING TEST PLAN

TESTS

\section{SERIES TEST PLAN}

likely, in a highly dispersed condition. In the event the fuel pins are in the nonfailed condition and further examinations are required, the requirements of Section 12.2 of TC-1361 will apply. Special examination requirements will be prepared by Transient Testing for the breached fuel pins. These requirements will reflect the findings of the post-test examination results obtained in HFEF. 


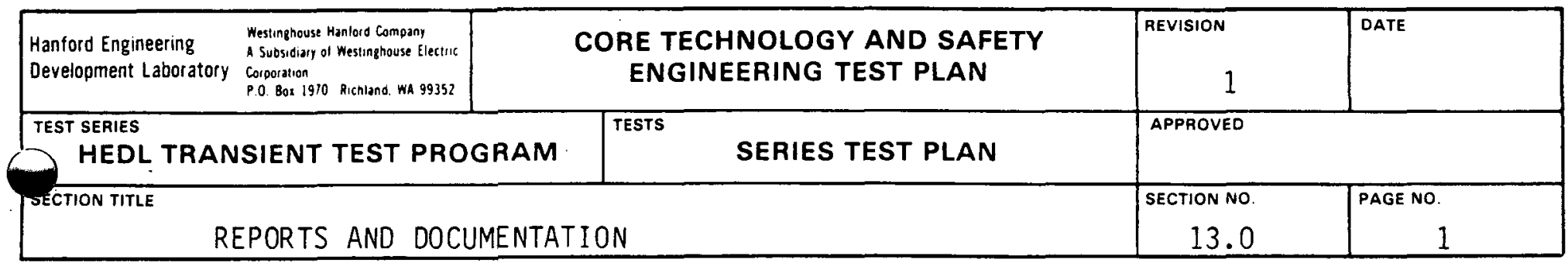

\subsection{REPORTS AND DOCUMENTATION}

13.1 Transient Testing will prepare and transmit the test specifications, safety analysis, test operating manual, and QA plan for approval and as-built dimensions and composition to the TREAT manager.

13.2 A formal topical report describing the results and conclusions of the test results shall be issued by Transient Testing after completion of al 1 analyses.

13.3 Each organization of 3.2 is required to report the progress of their activities in the monthly technical report.

13.4 Fabrication and Assembly shall prepare a loop fabrication and installation report, which shall include the following information as a minimum:

a. Design field changes showing any approved deviations from the initial plan.

b. Description of all nonconformances discovered during field fabrication, installation, and inspection with a description of approved action taken.

c. All procedures used (assembly, cleaning, pressure testing, welding, etc.).

d. Resistance readings.

e. Material certification and characterization results.

f. Helium leak detection and pressure test reports.

g. Weld qualification records and results.

h. Identification of production welds and the results of the nondestructive examination of each.

i. Cold reference position, as-built, of all piping with installation drawings updated to show final installed dimensions.

j. Completion records documenting acceptance for all required inspections and tests, and completion of work required work steps. 


\begin{tabular}{|c|c|c|c|c|c|}
\hline $\begin{array}{l}\text { Hanford Engineering } \\
\text { Development Laboratory }\end{array}$ & 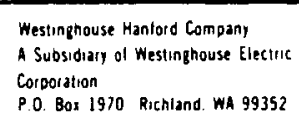 & \multicolumn{2}{|c|}{$\begin{array}{c}\text { CORE TECHNOLOGY AND SAFETY } \\
\text { ENGINEERING TEST PLAN }\end{array}$} & $\begin{array}{r}\text { REVISION } \\
1\end{array}$ & DATE \\
\hline \multicolumn{2}{|c|}{$\begin{array}{l}\text { TEST SERIES } \\
\text { HEDL TRANSIENT TEST PROGRAM }\end{array}$} & TESTS & SERIES TEST PLAN & \multicolumn{2}{|l|}{ APPROVED } \\
\hline CTION TITLE & EPORTS AND DOCl & TION & & $\begin{array}{r}\text { SECTION NO. } \\
13.0\end{array}$ & $\begin{array}{r}\text { PAGE NO. } \\
2\end{array}$ \\
\hline
\end{tabular}

13.5 Fabrication and Assembly shall prepare an operations logbook for each loop. This logbook is to accompany the loop to each test station. All inspections, operations, observations, TREAT tests, proof tests, or any other related activities are to be recorded, dated, and signed by the performer.

13.6 Component Fabrication shall prepare a fabrication report for the test train which shall include the following information as a minimum:

a. Design field changes showing any approved deviations from the initial plan.

b. Description of all nonconformances discovered during field fabrication, installation, and inspection with a description of approved action taken.

c. All procedures used (assembly, cleaning, pressure testing, welding, etc.).

d. Reșistance readings.

e. Material certification and characterization results.

f. Helium leak detection and pressure test reports.

g. Weld qualification procedures and weld qualification cards.

h. Identification of production welds and the results of the nondestructive examination of each.

i. As-built cold reference positions and the test train overall length.

j. Completion records documenting acceptance for a 11 required inspections and tests and completion of required work steps.

k. Displacement volume of the test train.

13.7 All quality records are to be maintained in accordance with Appendix A. 


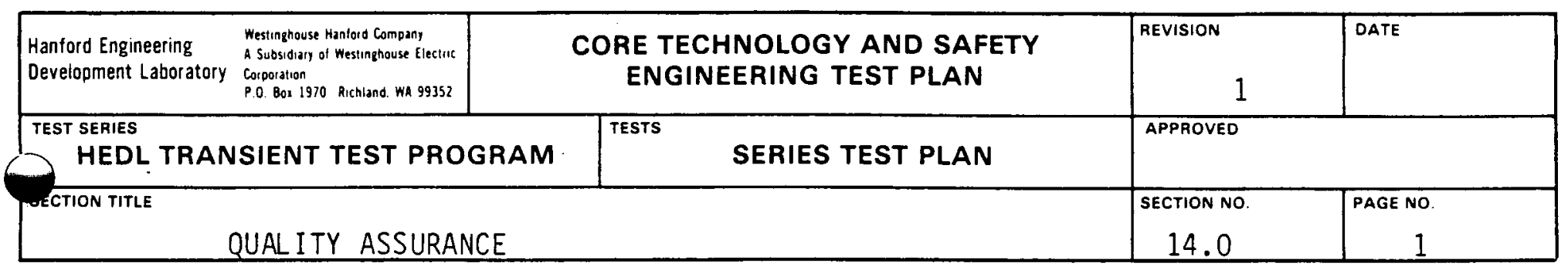

\subsection{QUALITY ASSURANCE}

\subsection{QUALITY ASSURANCE PROGRAM PLAN}

The Quality Assurance Plan for the HEDL Transient Test Program shall be in accordance with Section QAI 2-3, "Development Program Plans" of the HEDL Quality Assurance Manual MG-100. The appropriate quality assurance requirements are checked in $Q A$ Requirements Index, Table 14.1.1, and the hold points are specified in Table 14.1.2. The program's organization responsibilities are shown in Figure 14.1.1. The schedule for the first SPTL experiment is shown in Figure 14.1.2.

14.1.1 This development testing program is to be conducted in a consistent and standardized manner to provide the testing data in a timely fashion. The sequence of events for this test program will be shown in Figure 14.1.3. The contents of this Engineering Test Plan outline the responsibilities and the necessary requirements for execution of these events.

14.1.2 Drawing control lists shall be maintained for all project related drawings in accordance with Westinghouse Hanford Company Policy/Procedures No. 17-01 with the exception that Section $D$ be revised to read:

The minimum content of the list shall be as follows:

1. General Heading
a. Identification of company
b. Item or project
c. Date of issue
d. Copy number 
TABLE 14.1 .1

QUAL ITY ASSURANCE PROGRAM INDEX

Test Plan No. TC-1651 Rev 1

COMPONENT

Single Pin Test Loop (SPTL)

Single Pin Test Train (SPTT)
Title PFR/TREAT Safety Experiments - HEDL Transient Test Program

Engineering Test Plan

QA Level

Task Responsibility: List names of individuals and organizations responsible for the Development/Test Program.

Test Requester: L.A. Pember, Transient Testing

Test Performer: L.A. Pember, Transient Testing

$\begin{array}{ll}\text { Test Fabricator: } & \text { SPTT, JM Steffen - Component Fabrication; SPTL, JW Thornton - Fabrication and Assembly } \\ \text { Test 0perator: } & \text { TREAT, LJ Harrison }\end{array}$

Development Project Engr. (DPE): N/A

Cognizant Quality Engr. (CQE): W. H. Caplinger/P. S. Beutler - Quality Assurance Hold Points: The following Hold Points shall be observed. All required inspection and testing shall be completed
prior to proceeding beyond any hold point. Any nonconformances shall be resolved per Section 15 of
MG- 100 before further prossing 


\section{A. QUALITY ASSURANCE REQUIREMENTS:}

- Check the Q. A. Elements which apply to the test program.

- Line out any referenced HEDL procedures that do not apply.

- Add any other procedures that do apply.

- When no HEDL procedure is noted, refer to the applicable standard indicated.

- Use space provided to indicate the appropriate paragraph number of the Test Plan which explains any deviation from normal procedures or explains additional requirements.

- For any selected element which is denoted by an asterisk (*), either describe in the test plan how the element will be implemented, or provide a separate plan for it, as appropriate.

\section{Q.A. ELEMENT}

1. Management and Planning

(x) 1.1 Responsibility and Authority

(x) 1.2 Training and Indoctrination

(x) 1.3 Personnel Qualification

$(x) \star 1.4$ Quality Records

()$^{\star} 1.5$ Quality Status Reports

(x) 1.6 Corrective Action

(x) 1.7 Engineering Holds

(x) 1.8 Unusual Occurrence Reporting

2. Design and Deve lopment

(x) 2.1 Design Criteria

\begin{tabular}{ccc}
\multicolumn{3}{c}{ APPL ICABLE STANDARDS / PROCEDUR } \\
\cline { 1 - 2 } HEDL & RDT F2-2 & ANSI 45.2 \\
P/P 14-01 & 2.3 .1 & 1.3 \\
& 2.3 .2 & 2.0 \\
WHAN-M-15 & 2.3 .3 & 10.0 \\
(1) $17-1$ & 2.4 .2 & $7.0,18.0$ \\
& 2.4 .3 & 3.0 \\
(1) $16-1$ & 2.6 & 17.0 \\
& 2.7 & 4.0 \\
P/P 10-01 & 2.8 & 17.0
\end{tabular}

REMARKS

TEST PLAN

PARA. NO.

14.1 .5

14.1 .9

(1) Refer to Quality Assurance Manual MG-100 Section

\section{$3.3 .1 \quad 4.1$}


TABLE 14.1 .1 (Cont'd)

Q.A. ELEMENT

2. Design (Continued)

$(x)^{\star} 2.2$ Codes on Standards Assigned

()$\star 2.3$ Engineering Studies

( ) 2.4 Parts, Mat' 1 and Processes

$(x)^{\star 2.5}$ Design Description

$(x) * 2.6$ Specs., Dwgs. and Installation

$(x) \star 2.7$ Identification

( ) 2.8 Accept. Criteria

$(x) \star 2.9$ Interface Control

(x) 2.10 Doc. Review and Approval

2.11 Document Control

$(x) \star 2.12$ Owg. Control Lists

$(x) \star 2.13$ Design Review

( ) Formal

(x) Informa I

()$* 2.14$ Item Qualification

$(x) \star 2.15$ Quality Records

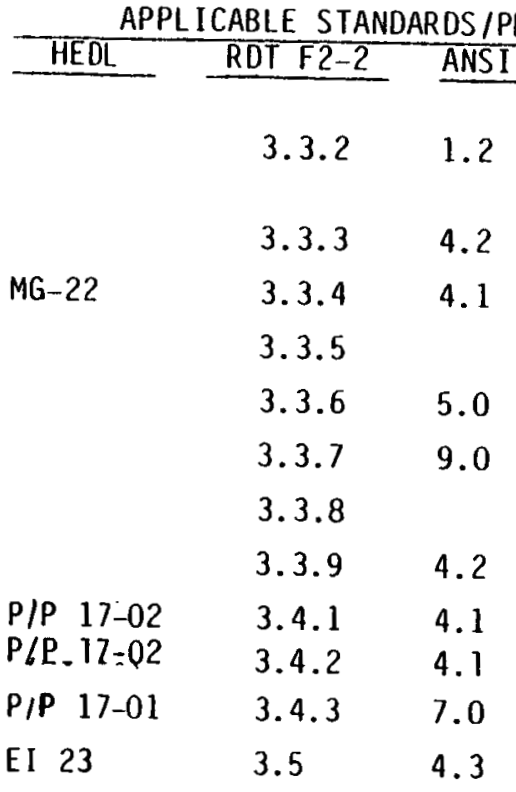

$3.7 \quad 4.3$

(1) $17-1 \quad 3.8 \quad 4.1,18$

TEST PLAN

PARA. NO
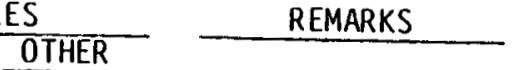

$\star 5.0$

$\star 4.0$

$\star 5.0$

7.1.9.2

$\star \underline{3.2}$

$\star 14.1 .2$

* 14.2

$\star 14.1 .5$

(1) Refer to Quality Assurance Manual MG-100 Section

(2) Satisfied by this test plan, including this QAPI and reference procedures 
TABLE 14.1.1 (Cont'd)

\section{Q.A. ELEMENT}

3. Procurement

(x) 3.1 Procurement Planning

(x) 3.2 Procurement Requirements

(x) 3.3 Document Review

(x) 3.4 Evaluation and Selection of Suppliers

(x) 3.5 Contract Change Control

( ) 3.6 "As-Built" Verification

(x) 3.7 Meas. and Test Equip. Control

( ) 3.8 Source Surveillance Insp.

(x) 3.9 Rec. Inspection

(x) Materials Overchecks

(x) 3.10 Nonconforming Item Control

(x) 3.11 Received Item Control

$(x)^{\star} 3.12$ Alloy Verification

(1) Refer to Quality Assurance Manual MG-100 Section

(1) 4
APPL I CABLE STANDARDS /PROCEDURES

\begin{tabular}{|c|c|c|}
\hline \multicolumn{3}{|c|}{ APPL ICABLE STANDARDS/PR } \\
\hline HEDL & & \\
\hline $\begin{array}{l}\text { (1) } 4 \\
M G-5\end{array}$ & 4.2 & 5.0 \\
\hline $\begin{array}{l}\text { (1) } 4 \\
M G-5\end{array}$ & 4.3 & 5.0 \\
\hline $\begin{array}{l}M G-5 \\
Q A I^{4} 4-1\end{array}$ & 4.4 & 5.0 \\
\hline QAI $4-2$ & 4.5 & 5.0 \\
\hline $\begin{array}{l}\text { QAI 4-1 } \\
M G-5\end{array}$ & 4.6 .1 & 5.0 \\
\hline $\begin{array}{l}\text { QAR } 4 \\
\text { MG-51 }\end{array}$ & 4.6 .2 & 18.0 \\
\hline (1) $12-1$ & 4.7 & 13.0 \\
\hline QAI 4-3 & 4.8 & 8.0 \\
\hline $\begin{array}{l}\text { QAI } 4-4 \\
\text { QAI } 4-5 \\
\text { MG-51 }\end{array}$ & 4.9 & 8.0 \\
\hline QAR 15 & 4.10 & 16.0 \\
\hline $\begin{array}{l}\text { QA I 8-1 } \\
\text { NFCL-38 } \\
\text { MG-52 }\end{array}$ & 4.11 & $\begin{array}{r}9.0 \\
14.0\end{array}$ \\
\hline
\end{tabular}

$M G-78$

4.13
TEST PLAN

PARA. NO.

REMARKS

$\star 6.1 .1 .2$ 
TABLE 14.1 .1 (Cont'd)

\section{Q.A. ELEMEN}

4. Fabrication

(x) 4.1 Insp. and Test Plan

(x) 4.2 Mat'l Ident. and Control

(x) 4.3 Fab. and Assembly Processes
$(x)$ Work Instructions
(x) Assembly Procedures
(x) Fol lower/Traveler Cards
(x) Assembly Logbooks

(x) 4.4 Process Qualification

$(x)$ Welding

(x) Chemical Analysis

() Other

(x) 4.5 Nondestructive Exam.

$(x) \star 4.6 \quad$ Cleaning

(x) 4.7 Insp. and Test Requirements

(x) 4.8 Insp. and Test Procedures

(x) 4.9 Completed Item Insp. and Test

(1) Refer to Quality Assurance Manual MG-100 Section
APPL ICABLE STANDARDS/PROCEDURES HEDL RDT F2-2 ANSI 45.2 OTHER

$\begin{array}{lll}\text { (1) } 10-1 & 5.3 & 6.0 \\ M G-51 & & \end{array}$

$M G-52$

5.4

9.0

(1) $8-1$

(1) $14-1 \quad 5.5 .1 \quad 6.0$

(1) $9-1 \quad 5.5 .2$

$M G-31$

$M G-28$

$\begin{array}{lll}\begin{array}{l}\text { WHAN-M-15 } \\ \text { MG-25 }\end{array} & 5.5 .3 & 10.0 \\ \text { (1) } 9 & & \\ \text { MG-19 } & 5.5 .4 & 14.0 \\ \text { (1) } 10-1 & 5.6 .1 & 11 ., 12 . \\ \text { (1) } 10-2 & 5.6 .2 & 11.12 . \\ \text { (1) } 10-6 & 5.6 .3 & 11 ., 12 .\end{array}$

TEST PLAN PARA. NO.

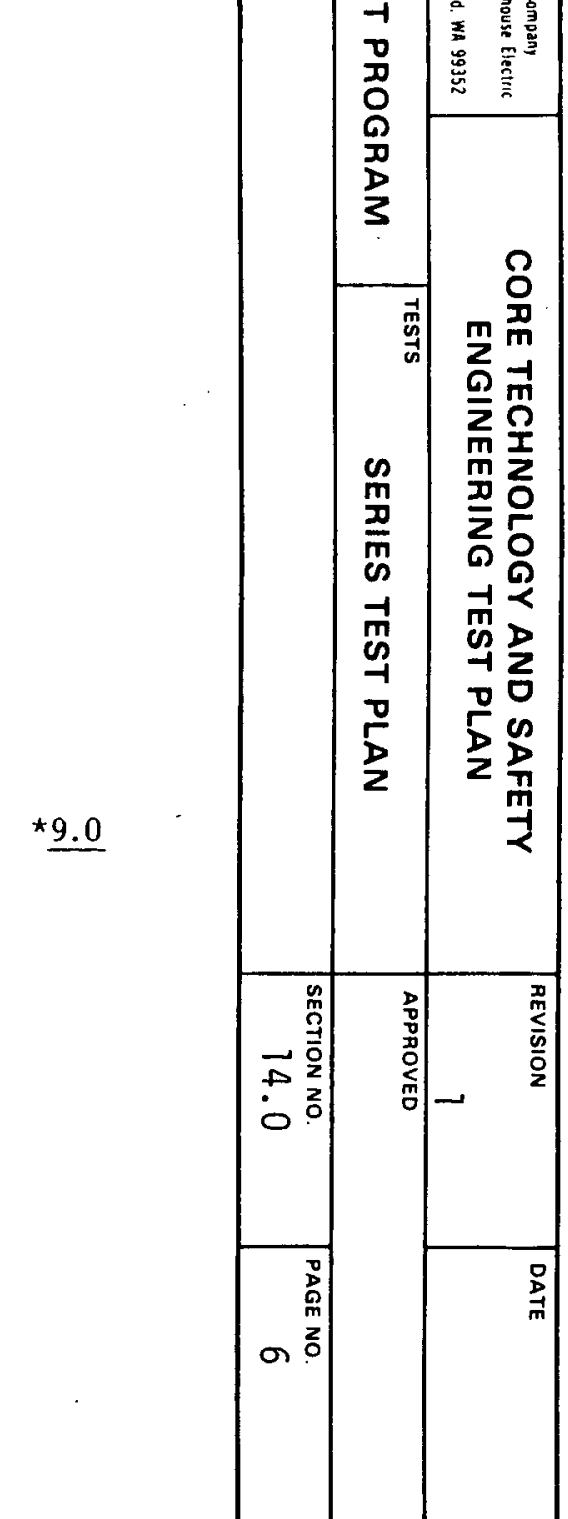


TABLE 14.1.1 (Cont'd)

\section{Q.A. ELEMENT}

4. Fabrication (Continued)

( ) 4.10 Insp. Status Indication $(x) \star 4.11$ Certification

$(x) \star 4.12$ Document Control

$(x) 4.13$ Meas. and Test Equip. Calib.

(x) 4.14 Statistical Q.C. and Anal.

(x) 4.15 Control of Nonconform. Items

(x) 4.16 Corrective Action

$(x) \star 4.17$ Handling, Storage and Shipping

$(x) \star 4.18$ Quality Records

$(x) \star 4.19$ Alloy Verification

(1) $17-1$

(1) 4

(1) $8-2$

APPL ICABLE STANDARDS/PROCEDURES

APPLICABLE STANDARDS/PROCEDURES
HEDL ROT F2-2 ANSI 45.2 OTHER

(1) $12-1$

(1) $12-2$

(1) $16-1 \quad 5.11 \quad 17.0$

\section{Testing}

$(x) \star 5.1$ Test Requirements and 0bjective

$(x) 5.2$ Test Planning

$(x) \star 5.3$ Test Procedures

$(x) \star 5.4$ Test I tem Characterization, Identification, Control and

Disposition

$\begin{array}{ll}3.6 .1 & 15.0 \\ 3.6 .2 & 15.0 \\ 3.6 .3 & 15.0 \\ 3.6 .4 & \end{array}$

REMARKS

\section{$5.6 .4 \quad 15.0$}

5.6 .5

5.7

7.0

5.8

13.0

5.9

5.10

16.0

TEST PLAN PARA. NO.

$5.12 \quad 14$

5.13

18

5.15

$\star 14.1 .3$

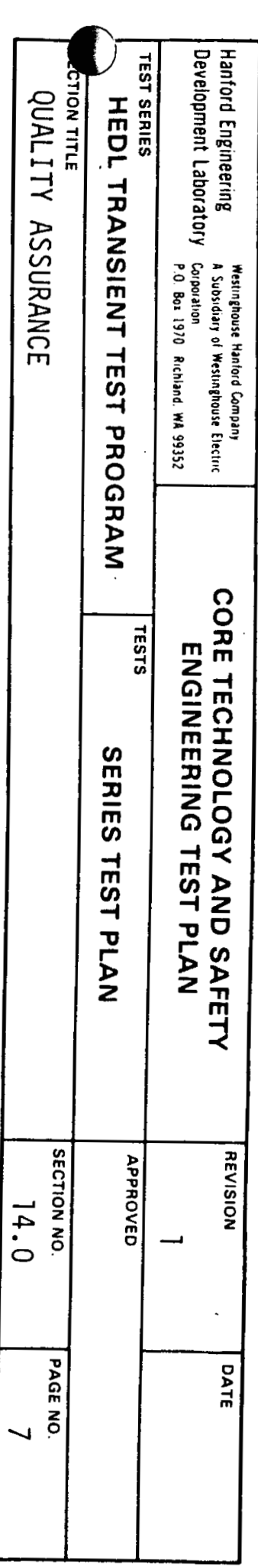

(1). Refer to Quality Assurance Manual MG-100 Section 
TABLE 14.1 .1 (Cont'd)

A. ELEMENT

5. Testing (Continued)

$(x) \star 5.5$ Test Equip. and Fluids Control

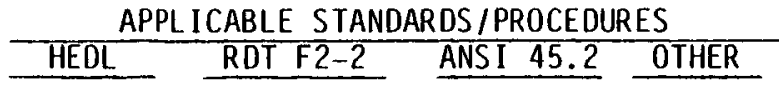

3.6 .5

3.6 .6

$(x) \star 5.6$ Data Acquis. Equip. and Method

3.6 .7

3.6 .8

( ) $\star 5.8$ Failure Analys is

$(x) \star 5.9$ Test Records, Analy., and Reports

( $)^{\star 5.10}$ Test Results Review

( )*5.11 Test Records

6. Quality Audits

(x) 6.1 Quality Audits

$-$

(1) 18

8.0

19

3.6.10 18.0

(1) Refer to Quality Assurance Manual MG-100 Section

PARA. NO.

$\star \underline{12.1 .9}$

12.1 .10

$\star 12.1 .8$

$\star 14.2$

$\star 13.2$

3.6.11 18.0

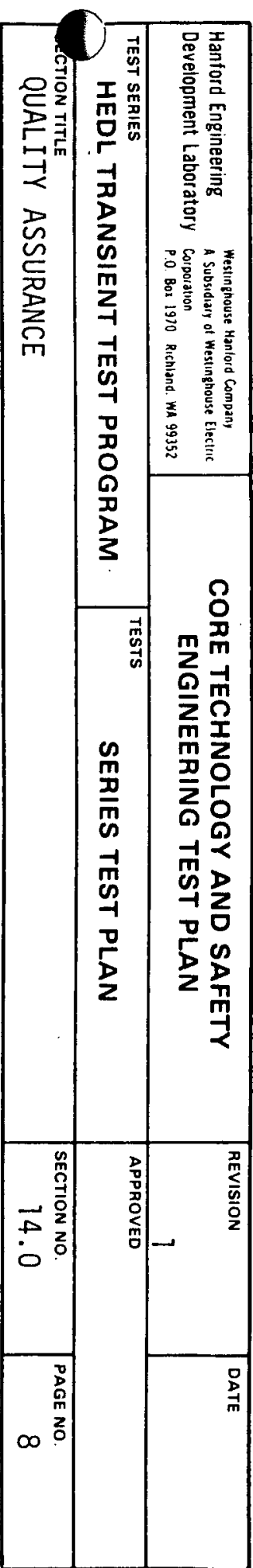




\begin{tabular}{|c|c|c|c|c|}
\hline $\begin{array}{l}\text { Hanford Engineering } \\
\text { Development Laboratory }\end{array}$ & $\begin{array}{l}\text { Westinghouse Hanlord Company } \\
\text { A Subsidiary of Messinghouse Electicic } \\
\text { Corporation } \\
\text { P.O. Box } 1970 \text { Richland. Wa } 99352\end{array}$ & $\begin{array}{c}\text { CORE TECHNOLOGY AND SAFETY } \\
\text { ENGINEERING TEST PLAN }\end{array}$ & $\begin{array}{r}\text { REVISION } \\
1\end{array}$ & DATE \\
\hline $\begin{array}{l}\text { TEST SERIES } \\
\text { HEDL TRAN }\end{array}$ & VSIENT TEST PROGRAM & SERIES TEST PLAN & \multicolumn{2}{|l|}{ APPROVED } \\
\hline SECTION TITLE & QUAL ITY ASSURANCE & & $\begin{array}{c}\text { SECTION NO } \\
14.0\end{array}$ & $\begin{array}{r}\text { PAGE NO. } \\
9\end{array}$ \\
\hline
\end{tabular}

\section{TABLE 14.1 .2 \\ HOLD POINTS FOR THE HEDL \\ TRANSIENT TEST PROGRAM}

The following hold points shall be observed by Quality Assurance in performing the requirements of this Engineering Test Plan. All required inspections and tests shall be completed before proceeding beyond any hold point. Any nonconformances shall be resolved per QAI 15-3 or 15-4 before further processing.

\section{Provisions for Release}

1. Receiving Inspection (Test Plan required at this point)

2. Technical Review Meeting Type No. 1

3. Technical Review Meeting Type No. 1

4. Technical Review Meeting Type No. 2

5. Test Train Components

6. Technical Review Meeting Type No. 2

7. Technical Review Meeting Type No. 2

8. Technical Review Meeting Type No. 3

9. Technical Review Meeting Type No. 4
Materials release card approved by Fuels Quality Control

Approval of series ETP and Drawings

Approval of ALIP and Flow Sensor Drawings

Approval of test train assembly plan

Length adjustment as required in Section 10.2.8 of this ETP

Approval of loop assembly plan

Approval of loop work plan

Approval of Fabrication Reports

for Test Train and Loop

Approval of Test Requirements 


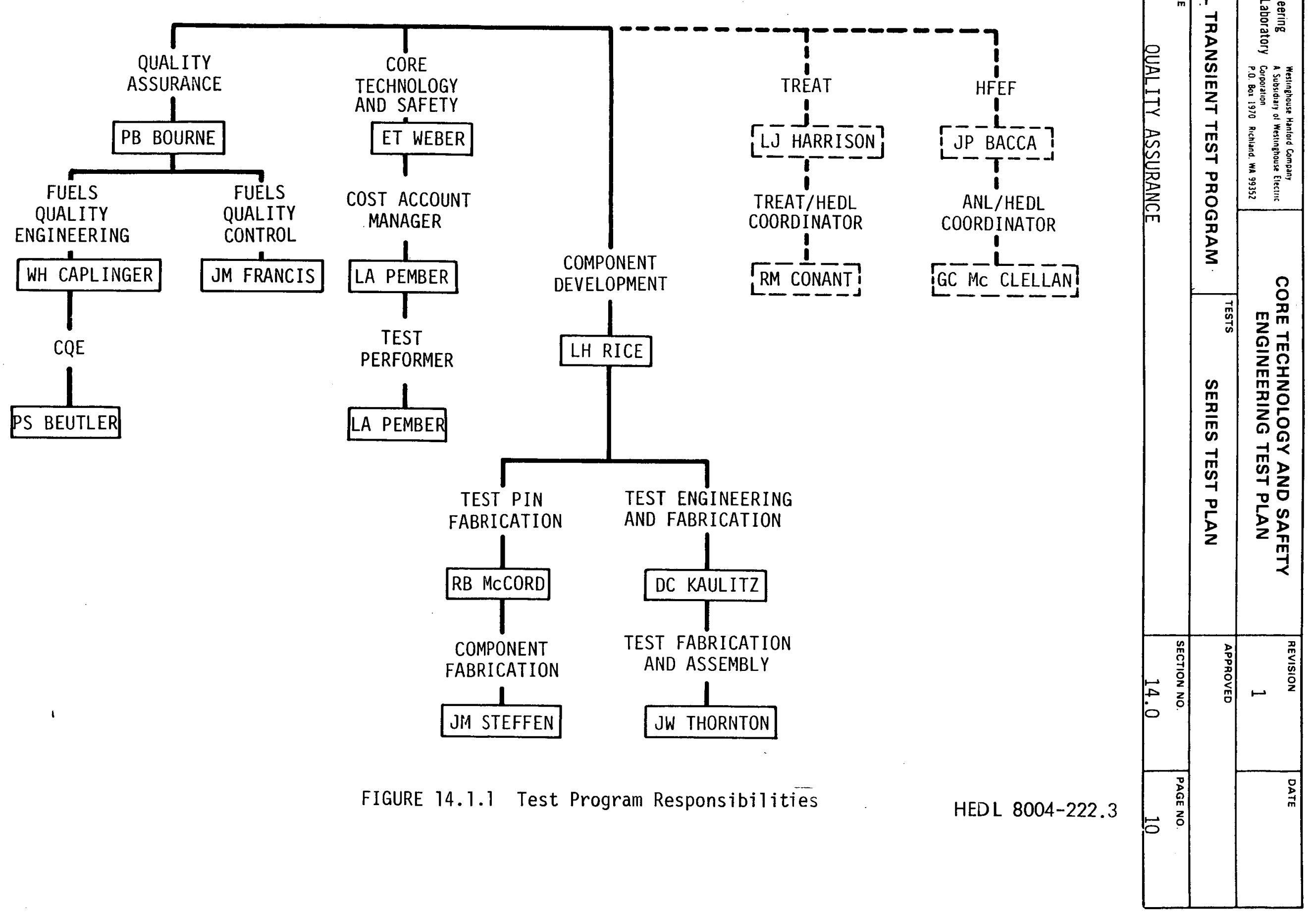




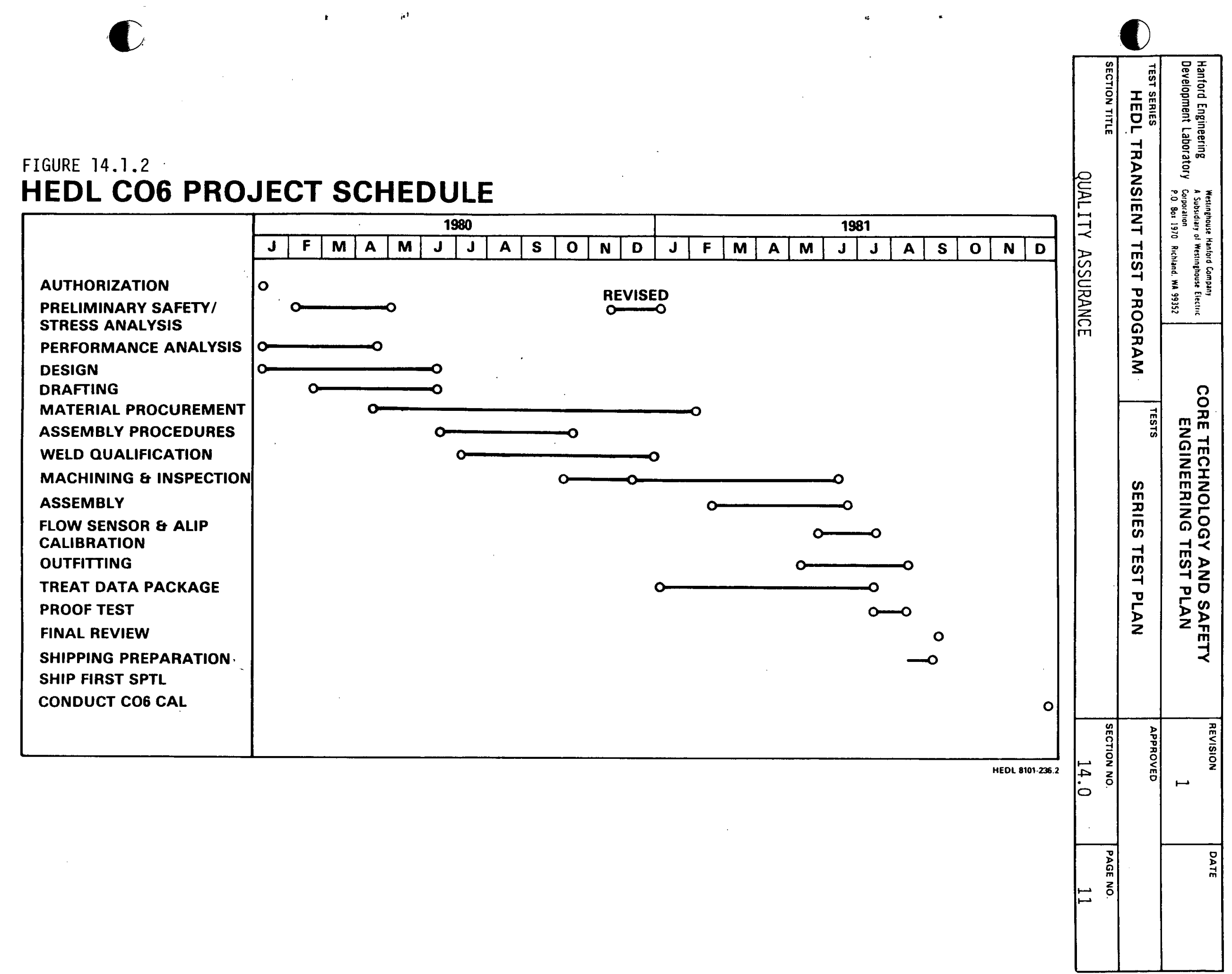

FIGURE 14.1 .2

HEDL CO6 PROJECT SCHEDULE

AUTHORIZATION

PRELIMINARY SAFETY

DESIGN

MACHINING \& INSPECTION

ASSEMBLY

SOR \& ALIP

CALIBRATION

PROOF TEST

FINAL REVIEW

SHIPPING PREPARATION.

SHIP FIRST SPTL

CONDUCT CO6 CAL 
FIGURE 14.1.3 HEDL TRANSIENT TEST

PROGRAM INTERFACE ACTIVITIES

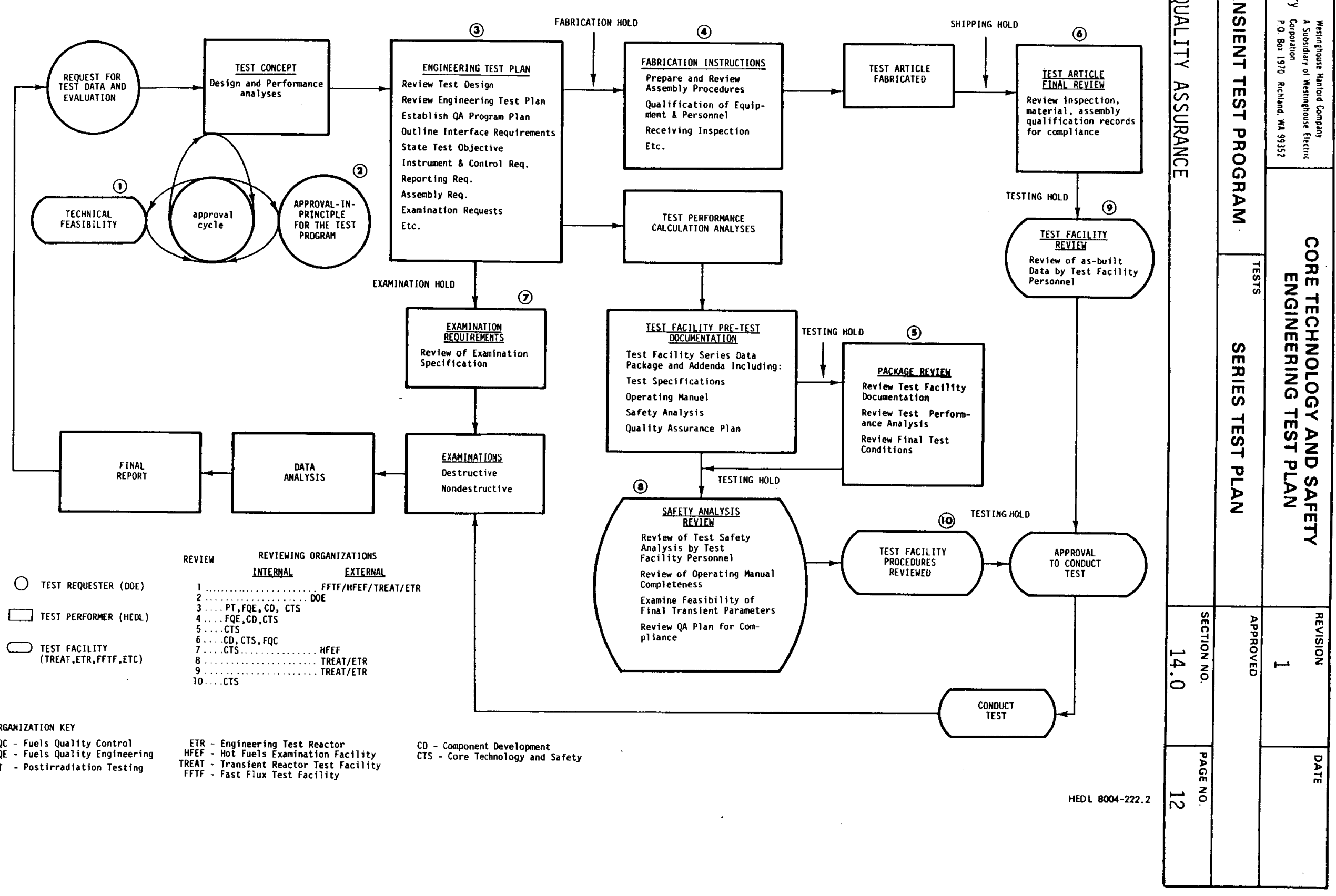




\begin{tabular}{|c|c|c|c|c|}
\hline $\begin{array}{l}\text { Hanford Engineering } \\
\text { Development Laboratory }\end{array}$ & 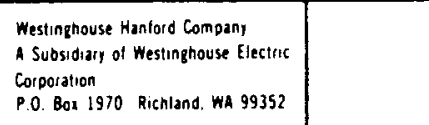 & $\begin{array}{c}\text { CORE TECHNOLOGY AND SAFETY } \\
\text { ENGINEERING TEST PLAN }\end{array}$ & $\begin{array}{r}\text { REVISION } \\
1 \\
1\end{array}$ & DATE \\
\hline $\begin{array}{l}\text { TEST SERIES } \\
\text { HEDL TRAN }\end{array}$ & ISIENT TEST PROGRAM & SERIES TEST PLAN & \multicolumn{2}{|l|}{ APPROVED } \\
\hline & QUAL ITY ASSURANCE & & $\begin{array}{c}\text { SECTION NO. } \\
14.0\end{array}$ & $\begin{array}{r}\text { PAGE NO. } \\
13\end{array}$ \\
\hline
\end{tabular}

2. Column Headings
a. Drawing number
b. Tit le
c. Revision number
d. Applicable Design Field Change. The extent of this requirement is to make visibile any changes to the design prior to revising the drawing.

14.1.3 Release of and changes to the project drawings and documents shall be in accordance with Westinghouse Hanford Company Policy/Procedure No. 17-02.

\subsubsection{Guidelines for NCR's:}

a. Rework is noted on work completion records, and an approved procedure will be used.

b. Repairs which alter the design require an NCR.

C. A11 supplier nonconformances require an NCR.

d. Al1 nonconformances accepted as is require an NCR.

e. Materials updated, by additional testing, to a higher level specification do not require an NCR if the material meets the original procurement specifications.

f. All failures and significant findings relevant to the original procurement specification resulting from upgrade testing are to be reported as an NCR. An NCR will be issued if requested by Quality Assurance.

g. Low cost onsite nonconformances $(<\$ 200)$ that have a low quality input do not require an NCR if the performer maintains scrap records that are auditable.

h. NCR's will be executed in accordance with FQE-0P-002 and QAR-15.

14.1.5 Project records shall meet the requirements of QAI 17-1, as out lined in Appendix A of this document, "Procedure for the HEDL Transient Test 


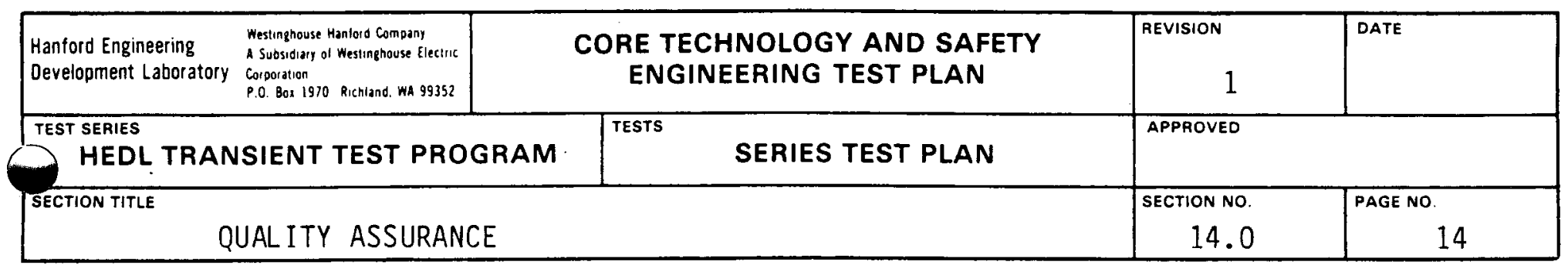

Program File System." Transient Testing shall maintain the master file for administrative and design activities. Component Fabrication shall maintain the file for test train fabrication and assembly activities. Fabrication and Assembly shall maintain the file for development, loop fabrication, assembly outfitting and proof testing activities. Transient Testing shall maintain the file for the irradiation testing activity. Postirradiation Testing Laboratory shall maintain the fuel pin logbooks and examination plans.

14.1.6 HEDL does not perform any external quality assurance audits of the Idaho National Engineering Laboratory (INEL) facilities. Audits of the INEL facilities are to be scheduled and performed by DOE/HQ.

14.1.7 Unusual Occurrence Reports are to be prepared for all unusual or unplanned occurrences having programmatic significance which occur during design, development, fabrication, operation, testing, etc., of the project test articles, interface components, systems, structures, etc. An unusual or unplanned event is defined as any event outside the norm of operations that, (1) causes or risks serious injury to personnel, or (2) has significant effect upon the safety, reliability, availability, operability, or cost of the programmatic test articles, facilities, systems or equipment, etc. External organizations, HFEF and TREAT, are to prepare Unusual Occurrence Reports, when required, in accordance with the requirements of RDT Standard F1-3. All HEDL organizations are to prepare Unusual Occurrence Reports, when required, in accordance with the requirements of Westinghouse Hanford Company Policy/Procedure No. 10-01.

14.1.8 Fabrication and assembly processes, instructions, procedures, and traveler cards of Section 4.3 of Table 14.1 .1 and the inspection procedures and tests of Section 4.8 of Table 14.1 .1 may or may not be included in one comprehens ive document.

14.1.9 Engineering holds shall be identified in this ETP (Table 14.1.2) or circles on the engineering drawing and identified as an engineering hold. 


\begin{tabular}{|c|c|c|c|c|}
\hline $\begin{array}{l}\text { Hanford Engineering } \\
\text { Development Laboratory }\end{array}$ & 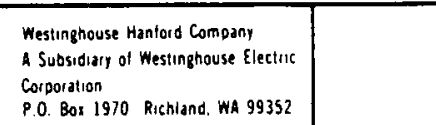 & $\begin{array}{c}\text { CORE TECHNOLOGY AND SAFETY } \\
\text { ENGINEERING TEST PLAN }\end{array}$ & $\begin{array}{r}\text { REVISION } \\
1 \\
1\end{array}$ & DATE \\
\hline $\begin{array}{l}\text { TEST SERIES } \\
\text { HEDL TRAN }\end{array}$ & VSIENT TEST PROGRAM & SERIES TEST PLAN & \multicolumn{2}{|l|}{ APPROVED } \\
\hline \multicolumn{2}{|r|}{ QUAL ITY ASSURANCE } & & $\begin{array}{c}\text { SECTION NO. } \\
14.0\end{array}$ & $\begin{array}{r}\text { PAGE NO } \\
15 \\
\end{array}$ \\
\hline
\end{tabular}

Transient Testing will maintain a list of each engineering hold. A DFC will be required to remove an engineering hold.

14.1.10 Audit planning will be in accordance with HEDL MG-100, QAI 18-2, and will be scheduled by HEDL-QA. Audit schedules are based on the HEDL Internal Audit Planning Matrix.

\subsection{TECHNICAL REV IEW MEETINGS}

The intent of the technical reviews is to ensure that the test objectives are met in an orderly and timely fashion. The major review meetings required to meet the objectives of this test program and the organization responsible for chairing each meeting are as follows:

Technical Review Type

1. Test Article Design and Program Transient Testing Documentation

2. Work procedures

3. Test Article Fabrication Review

4. Test Conditions

\section{Chairing Organization}

Component Fabrication/Fabrication and Assembly

Component Fabrication/Fabrication and Assembly

Transient Testing

The chairman shall be responsible for formally notifying the organization involved as to the date, location and the necessary records that are to be supplied by each. The responsibility for compiling the review records will be with the responsible organization. In the event the review is not favorable, the necessary corrections shall be made prior to approval. At least one review meeting shall be held for each of the technical review types, and additional meetings may be required if design changes, test conditions, etc., change. In addition to the four types of technical review meetings specified above, other reviews are to be conducted as outlined in Figure 14.1.3. Signature Approval is required by the responsible organization of Figure 14.1.3. 


\begin{tabular}{|c|c|c|c|c|c|}
\hline $\begin{array}{l}\text { Hanford Engineering } \\
\text { Development Laboratory }\end{array}$ & 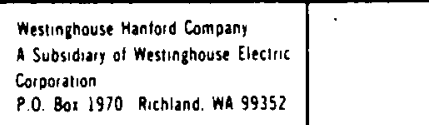 & \multicolumn{2}{|c|}{$\begin{array}{c}\text { CORE TECHNOLOGY AND SAFETY } \\
\text { ENGINEERING TEST PLAN }\end{array}$} & $\begin{array}{r}\text { REVISION } \\
\\
1\end{array}$ & DATE \\
\hline $\begin{array}{l}\text { TEST SERIES } \\
\text { HEDL TRAN }\end{array}$ & ISIENT TEST PROGRAM & TESTS & SERIES TEST PLAN & \multicolumn{2}{|l|}{ APPAOVED } \\
\hline \multicolumn{2}{|r|}{ QUAL ITY ASSURANCE } & & & $\begin{array}{c}\text { SECTION NO. } \\
14.0\end{array}$ & $\begin{array}{r}\text { PAGE NO. } \\
16\end{array}$ \\
\hline
\end{tabular}

14.2.1 Technical Review Meeting Type No. 1

Review the series engineering test plan, test plan addendum, test train design addendum and/or fuel pin design addendum. The test train and loop designs shall be presented at this meeting for review. Depending on the nature of the review meeting, the managers from the appropriate organizations cited in Section 3.2 will be notified by Transient Testing, and a representative from each shall be present at the meeting.

\subsubsection{Technical Review Meeting Type No. 2}

A design review meeting is to be held with representatives of Transient Testing, Fuels Quality Engineering, Component Fabrication or Fabrication and Assembly to review the test train or loop work procedures or instructions.

\subsubsection{Technical Review Meeting Type No. 3}

A final review will be held with representatives of Transient Testing, Fabrication and Assembly, Component Fabrication, Postirradiation Testing and Fuels Quality Engineering. At that time, the radiographs, material certifications, thermocouple data, fabrication follower cards, as-built dimensions, nondestructive fuel pin examination results, etc., are to be reviewed for the outfitted loop, test train, and fuel pins prior to release for shipping. The fabrication data packages for the outfitted and proof tested loops, as well as the fabrication data package for the test train assembly, should be reviewed at this meeting.

\subsubsection{Technical Review Meeting Type No. 4}

This review meeting will be held within Transient Testing Section prior to transmittal of the test data package to TREAT. This is to ensure that the desired irradiation condition to be specified in the data package will meet the intent of the test. 


\begin{tabular}{|c|c|c|c|c|}
\hline $\begin{array}{l}\text { Hanford Engineering } \\
\text { Development Laboratory }\end{array}$ & $\begin{array}{l}\text { Westinghouse Hantord Company } \\
\text { A Subsidiary of Westinghouse Eiecticic } \\
\text { Corporation } \\
\text { P.0. Box } 1970 \text { Richland. WA } 99352\end{array}$ & $\begin{array}{c}\text { CORE TECHNOLOGY AND SAFETY } \\
\text { ENGINEERING TEST PLAN }\end{array}$ & $\begin{array}{r}\text { REVISION } \\
1\end{array}$ & DATE \\
\hline $\begin{array}{l}\text { TEST SERIES } \\
\text { HEDL TRAN }\end{array}$ & ISIENT TEST PROGRAM & SERIES TEST PLAN & \multicolumn{2}{|l|}{ APPROVED } \\
\hline \multicolumn{3}{|l|}{ SECTION TITLE } & SECTION NO. & $\begin{array}{r}\text { PAGE NO. } \\
1\end{array}$ \\
\hline
\end{tabular}

\section{REFERENCES}

1. D. R. Porten, "Engineering Test Plan for the US/UK Safety Test Program Static Capsule Test Series," TC-1439, Hanford Engineering Development Laboratory, Richland, WA, August 1979. 


\begin{tabular}{|c|c|c|c|c|}
\hline $\begin{array}{l}\text { Hanford Engineering } \\
\text { Development Laboratory }\end{array}$ & 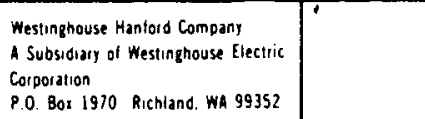 & $\begin{array}{c}\text { CORE TECHNOLOGY AND SAFETY } \\
\text { ENGINEERING TEST PLAN }\end{array}$ & $\begin{array}{r}\text { REVISION } \\
1\end{array}$ & DATE \\
\hline \multicolumn{2}{|c|}{$\begin{array}{l}\text { TEST SERIES } \\
\text { HEDL TRANSIENT TEST PROGRAM }\end{array}$} & SERIES TEST PLAN & \multicolumn{2}{|l|}{ APPAOVED } \\
\hline \multicolumn{3}{|c|}{$\begin{array}{ll}\text { SECTION TITLE } \\
\text { APPENDIX A }\end{array}$} & SECTION NO. & $\begin{array}{r}\text { PAGE NO. } \\
\text { A-1 }\end{array}$ \\
\hline
\end{tabular}

$i^{2}$

APPENDIX A

PROCEDURES FOR THE HEDL TRANSIENT

TEST PROGRAM FILE SYSTEM 


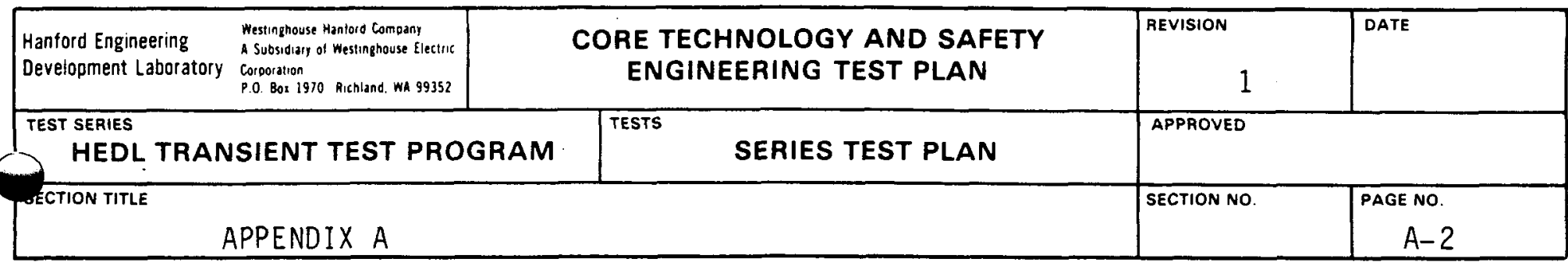

APPENDIX A

PROCEDURES FOR THE HEDL TRANSIENT

TEST PROGRAM FILE SYSTEM

$-$

I. GENERAL REQUIREMENTS

Transient Testing, Component Fabrication, and Fabrication and Assembly are to maintain their respective file systems in accordance with the requirements of QAI 17-1 and requirements specified herein.

\section{ACCESS TO QUALITY RECORDS}

The Cost Account Manager and/or his designated representatives shall have access to all HEDL program files. Each organization's management, cognizant program engineer and individuals designated by the cognizant engineer are to have access to their respective loop program files.

III. CUSTODIANS

IV. FILE LOCATIONS AND IDENTIFICATION

Each organization shall provide the following information. 


\begin{tabular}{|c|c|c|c|c|}
\hline $\begin{array}{l}\text { Hanford Engineering } \\
\text { Development Laboratory }\end{array}$ & $\begin{array}{l}\text { Westinghouse Hanlord Company } \\
\text { A Subsitiary ol Westinghouse Electiric } \\
\text { Corporation } \\
\text { P. } 0 \text { Bor } 1970 \text { Richiand. Wh } 99352\end{array}$ & $\begin{array}{c}\text { CORE TECHNOLOGY AND SAFETY } \\
\text { ENGINEERING TEST PLAN }\end{array}$ & $\begin{array}{r}\text { REVISION } \\
1\end{array}$ & DATE \\
\hline \multicolumn{2}{|c|}{$\begin{array}{l}\text { TEST SERIES } \\
\text { HEDL TRANSIENT TEST PROGRAM }\end{array}$} & SERIES TEST PLAN & \multicolumn{2}{|l|}{ APPROVED } \\
\hline \multicolumn{2}{|r|}{ APPENDIX A } & & SECTION NO. & $\begin{array}{r}\text { PAGE NO. } \\
\text { A-3 }\end{array}$ \\
\hline
\end{tabular}

Organization

\section{File Location File Identification Custodian}

Transient Testing

Component Fabrication

Fabrication and Assembly

V. RETENTION TIME

Each organization shall turn over their quality record to Transient Testing upon completion of their respective activities. Transient Testing will turn over all records to Records Accountability upon completion of the project. All quality records are classified as permanent. Retention times are to be reclassified in accordance with the requirements of QAI 17-1 upon completion of the project.

VI. QUALITY RECORDS

Quality records are those designated in QAI 17-1 Attachment I. 


\begin{tabular}{|c|c|c|c|c|}
\hline $\begin{array}{l}\text { Hanford Engineering } \\
\text { Development Laboratory }\end{array}$ & 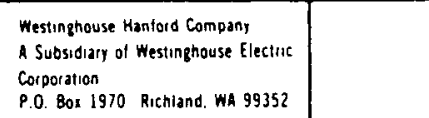 & $\begin{array}{c}\text { CORE TECHNOLOGY AND SAFETY } \\
\text { ENGINEERING TEST PLAN }\end{array}$ & $\begin{array}{r}\text { REVISION } \\
1\end{array}$ & DATE \\
\hline \multicolumn{2}{|c|}{ 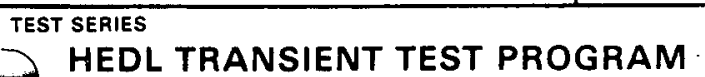 } & SERIES TEST PLAN & \multicolumn{2}{|l|}{ APPROVED } \\
\hline \multicolumn{3}{|c|}{ APPENDIX B } & SECTION NO. & $\begin{array}{r}\text { PAGE NO. } \\
\text { B-1 }\end{array}$ \\
\hline
\end{tabular}

\section{APPENDIX B}

SPTL DRAWING LIST

Drawing No.

$H-3-47080$

RO 202-0159-DB

$\mathrm{H}-3-47084$

$\mathrm{H}-3-47206$

H-3-47653

H-3-47654

H-3-47655

$\mathrm{H}-3-47656$

H-3-47129

R0 225-0103-DB

RO 225-0104-DB

R0 225-0128-DC

RO 225-0129-DB

RO 225-0122-DB

RO 202-0131-DC

RO 202-0130-DB

RO 202-0206-DB

RO 202-0196-DB
Tit le

Single Pin Test Loop Subassembly

Index Ring

Pump Assembly

Flow Sensor Details

SPTL Pump Flowtube/

Core Assembly

SPTL Pump Stator Details
Sheet Rev. No.

1
2
3

2

3

4
5

$$
6
$$

7

1

1

1

1

2

1

\section{2}

3

4

5

SPTL Pump Insulator Tube Aśsembly

SPTL Pump Calibration Assembly

SPTL Outfitting and Finish Piping Assembly

Guide Post

Mounting Post

Twin Connector Mounting Block

Spreader Bar

Flat Gasket

Clamp (Closure Flange)

Bolt-Clamp (Closure Flange)

$B l$ ind Closure Flange

Seal Ring (Closure Flange) 


\begin{tabular}{|c|c|c|c|c|}
\hline $\begin{array}{l}\text { Hanford Engineering } \\
\text { Development Laboratory }\end{array}$ & 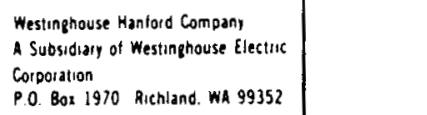 & $\begin{array}{c}\text { CORE TECHNOLOGY AND SAFETY } \\
\text { ENGINEERING TEST PLAN }\end{array}$ & $\begin{array}{r}\text { REVISION } \\
1\end{array}$ & DATE \\
\hline \multicolumn{2}{|c|}{$\begin{array}{l}\text { TEST SERIES } \\
2 \text { HEDL TRANSIENT TEST PROGRAM }\end{array}$} & SERIES TEST PLAN & \multicolumn{2}{|l|}{ APPROVED } \\
\hline \multicolumn{3}{|c|}{$\begin{array}{ll}\text { SECTION TITLE } & \\
& \text { APPENDIX } B\end{array}$} & SECTION NO. & $\begin{array}{l}\text { PAGE NO. } \\
\text { B-2 }\end{array}$ \\
\hline
\end{tabular}

SPTL DRAWING LIST (Cont'd)

Drawing No.

RO 230-0029-DD Can Subassembly

RO 230-0280-DC

RO 225-0191-DB

RO 230-0043-DD

RO 230-0188-DD

RO 230-0189-DC

RO 225-0190-DD

$\mathrm{H}-3-47220$

RO 202-0109-DB

RO 202-0110-DB

RO 202-0116-DB

RO 202-0111-DB

R0 202-0112-DB

RO 225-0015-DB

RO 225-0409-DB

RO 225-0410-DB

RO 202-0014-DC

ETD-1-56727-B

ETD-1-56726-C

ETD-1-56820-A

ETD-1-56728-A

$\mathrm{H}-3-47130$

H-3-47131

C.
Tit le

Shoe

Spring Rework

Can Body Weldment Subassembly

Body Can

Bottom-Can

F lange-Can

Hood Assembly

B lock-Pin Lock

Guide Block

Spacer

Shim Plate

Retainer Ring

Hood Bolt Subassembiy

Nut-Acorn (Rework)

Bolt

Hood Weldment Subassembly

Top for Hood

Hood Body

Pad

Guide Block

SPTL Electrical Outfitting

SPTL Final Assembly
Sheet Rev. No.

1

1

1

1

1

1

1

1

1

1

1

1

1

1

1

1

1

1

1

1

1

1 


\begin{tabular}{|c|c|c|c|c|}
\hline $\begin{array}{l}\text { Hanford Engineering } \\
\text { Development Laboratory }\end{array}$ & $\begin{array}{l}\text { Wessunghouse Hantord Company } \\
\text { A Subsidary of Westinghouse Electric } \\
\text { Corporation } \\
\text { P.O. Bo1 } 1970 \text { Richland. WA } 99352\end{array}$ & $\begin{array}{c}\text { CORE TECHNOLOGY AND SAFETY } \\
\text { ENGINEERING TEST PLAN }\end{array}$ & $\begin{array}{r}\text { REVISION } \\
1\end{array}$ & DATE \\
\hline $\begin{array}{l}\text { TEST SERIES } \\
\text { HEDL TRAN }\end{array}$ & SIENT TEST PROGRAM & SERIES TEST PLAN & \multicolumn{2}{|l|}{ APPROVED } \\
\hline \multicolumn{2}{|c|}{ APPENDIX C } & & SECTION NO. & $\begin{array}{r}\text { PAGE NO. } \\
\text { C-1 }\end{array}$ \\
\hline
\end{tabular}

APPENDIX C

SPTT DRAWING LIST

Drawing No.

$H-3-47103$

H-3-38137

H-3-47886

H-3-47879

ETD-1-56783-B

RP-1-44936-A
Tit le

Single Pin Test Train

Test Train Bellows

Inlet Plenum Region, Pin

Positioning Flow Tube Assembly

Adiabatic Region Pin Positioning

Flow Tube Assembly

Closure Flange

Seal Ring, $T / C$ Exit
Sheet Rev. No.

1

1

1

1

1

1

1

1

1

1

0

10

1

A

1 


\section{DISTRIBUTION}

DOE/RRT-HQ (3)

Director, Safety \& Physics Division

H. Alter (2)

DOE/FFTFPO (2)

Director, Operational \& Experimental Safety Division

K. R. Absher

DOE/INEL (1)

Director, Chicago Office

DOE/CORO (1)

Director

ANL/FRS-TMC (5)

HEDL (59)

Director (2)

G. E. Cutley (2)

H. G. Barrus (12)

W/A-106

D. J. Hill

P. S. Beutler

W/A-46

M. J. Blasde 7

$W / E-9$

ANL/E (4)

W. F. Brown

$W / C-34$

W. H. Caplinger

W/A-99

C. M. CoX

A. J. Goldman (2)

T. A. Delucchi

R. A. Noland (2)

P. C. Ferrell

W. H. Gray

R. G. Henderson

GE/ARSD (2)

M. A. Hoffman (2)

D. B. Atcheson (2)

E. J. Manthos

M. E. McMahan

I. L. Metcalf

$W / E-2$

$W / C-19$

W/E-9

W/A-103

W/E-9

W/A-106

W/E -9

ANL/W (6)

Manager, TREAT Facility (2)

Experiment Coordinator, TREAT Facility

Manager, HFEF Complex (2)

Experiment Coordinator, HFEF Facility

UKAEA/RISLEY

C. B. Cowking (2)

UKAEA/WINFRITH (2)

W. J. Woods (2)

D. L. Myron

L. A. Pember

$W / C-54$

$W / E-9$

W/E-9

$W / E-9$

$W / E-9$

$W / A-72$

J. M. Seay

L. D. Sharp

$W / E-9$

J. M. Steffen (12)

$W / C-19$

$J$. R. Thielges

W/E-9

W/A-106

J. W. Thornton

A. E. Waltar

E. T. Weber

$W / C-79$

$W / E-4$

PFR/TREAT Files (5)

Pub. Services (2)

W/E-9

$W / C-123$

Cent. Files (5)

$W / C-110$ 